\title{
PACCT -4449
}

Rensselaer Polytechnic Institute

Troy, New York

Tinal Report

Contract No. At $(30-3)-241$

A Study of Complex Ions In

Fused Salt Systems

Submitted by

R.A. Osteryoung

J.D. VanNormam

J.H. Christie

September 17, 1959 


\section{DISCLAIMER}

This report was prepared as an account of work sponsored by an agency of the United States Government. Neither the United States Government nor any agency Thereof, nor any of their employees, makes any warranty, express or implied, or assumes any legal liability or responsibility for the accuracy, completeness, or usefulness of any information, apparatus, product, or process disclosed, or represents that its use would not infringe privately owned rights. Reference herein to any specific commercial product, process, or service by trade name, trademark, manufacturer, or otherwise does not necessarily constitute or imply its endorsement, recommendation, or favoring by the United States Government or any agency thereof. The views and opinions of authors expressed herein do not necessarily state or reflect those of the United States Government or any agency thereof. 


\section{DISCLAIMER}

Portions of this document may be illegible in electronic image products. Images are produced from the best available original document. 


\section{Prologue}

This report is subnitted in two parts. Part $I$ is in the forn of a thesis submitted by John D. VanNorman to the faculty of the Chemistry Department of Renssolaer Polytechnic Institute in partial fulfillnent of the roquirenents for the Degree, Doctor of Philosophy. The thesis covers work done by Mr. VanNorian since the beginning of the contract, June 18, 1956 .

Part II is a report of the work corpleted by $M r$. Joe H. Christie in the period June 1959-August 1959. 


\section{Part I}

A Study of Sone Reactions in

Fused Chlorides and Nitrates 
Table of Contents

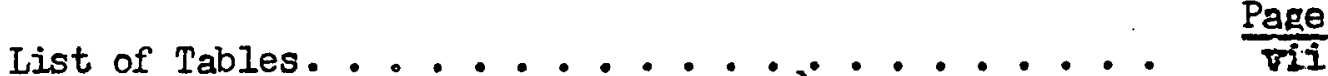

List of Figures ................ viii

Abstract. ................ $x$

I. INTRODUCTION

A. Historical Review. ........... I 1

B. Statement of Problem ............ 3

II. TEEORY

A. Fused Salts as Solvents. . . . . . . . 5

B. High Temperature Acids and Bases . . . . . 5

C. Theory of Iight Absorption ......... 8

D. Method of Continuous Variation ....... 9

E. McConnell-Davidson Technique of Evaluating Formation Constants of Complex Ions . . . . 10

F. Spectrophotometric Determination of Formation Constants for Complex Ions Using Sparingly

Soluble Salts ............

III. MATERIAIS AND APPARATUS

A. Materials. . . . . . . . . . . 15

B. Apparatus.................. 16

1. High Temperature Spectrophotometer . . . 16

2. Temperature Controller ........ 20

3. Filtration Apparatus . . . . . . . 25

4. Reaction Vessel............ . 27

5. Mass Spectrometer........... 27

6. Miscellaneous Apparatus....... . 30

IV. EXPERTMENTAL PROCEDURES

A. Preparation and Purification of Salts...... 31

1. $\mathrm{LiNO}_{3}-\mathrm{KNO}_{3}$ Eutectic. .......... 31

2. $\mathrm{KNO}_{3}-\mathrm{NaNO}_{3}$ Eutectic. .......... 31

3. LiCl-KCl Eutectic........... 32

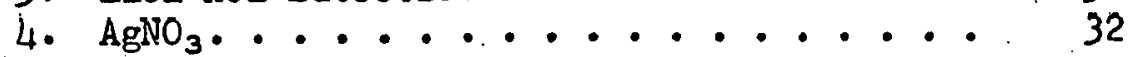


Table of Contents (Cont'd)

B. Spectrophotometric Investigations...... $\frac{\text { Page }}{33}$

1. Cobalt-Chloro Complexes in $\mathrm{LiNO}_{3}-\mathrm{KNO}_{3}$ Eutectic .............. 33

2. Spectral Studies of Chromium Salts in

Nitrate Melts. ......... 34

3. Spectral Studies of Chromium Salts in

LiCl-KCl Eutectic......... 35

4. Spectral Studies of Lead Halide Complexes in $\mathrm{KNO}_{3}-\mathrm{NaNO}_{3} \ldots \ldots \ldots$

C. Gas Evolution Investigations ........ 37

1. Mass Spectral Studies of the Gaseous Products of the Dichromate-Nitrate Reaction . in Fused $\mathrm{KNO}_{3}-\mathrm{NaNNO}_{3}$ Eutectic ...... 37

2. Determination of Acidic Oxy-Anions by $\mathrm{CO}_{2}$ Evolution...........

V. EXPERTMENTAL RESULTS

A. Spectrophotometric Investigations....... 41

1. Spectral Studies of the Cobalt-Halide Complexes in $\mathrm{LiNO}_{3}-\mathrm{KNO}_{3}$ Eutectic .... 41

2. Spectral Studies of Chromium Salts in Various Nitrate Melts....... 45

3. Spectral Studies of Chromium Salts in IiCl-KCl Eutectic. . . . . . . 60

4. Spectrophotometric Determination of Formation Constants of Lead-Chloro and LeadBromo Complexes in $\mathrm{KNO}_{3}-\mathrm{NaNO}_{3}$ Eutectic .

5. Lead-Iodo Complexes......... 72

B. Gas Evolution Investigations ........ 74

1. Mass Spectral Studies of the Products of the Dichromate-Nitrate Reaction in

Fused $\mathrm{KNO}_{3}-\mathrm{NaNO}_{3} \ldots \ldots . \ldots 74$

2. Determination of Acidic Oxy-Anions in Fused Salts by $\mathrm{CO}_{2}$ Evolution ..... 77

C. Acid-Base Reactions in Fused Salts ...... 79 
Table of Contents (Cont'd)

Page

VI. DISCUSSION OF RESULTS

A. Spectrophotometric Investigations....... 81

1. Spectral Studies of the Cobalt-Halide Complexes in $\mathrm{LiNO}_{3}-\mathrm{KNO}_{3}$ Eutectic .... 81

2. Spectral Studies of Chromium Salts in

Various Nitrate Melts........ 83

3. Spectral Studies of Chromium Salts in

LiCl-KCl Eutectic. ......... 86

4. Spectrophotometric Determination of

Formation Constants of Lead-Chloro and Lead-Bromo Complexes in $\mathrm{KNO}_{3}-\mathrm{NaNO}_{3}$. 87

5. Investigation of Lead-Iodo Complexes in $\mathrm{KNO}_{3}-\mathrm{NaNO}_{3} \ldots \ldots 8 . \ldots . . . . . .28$

B. Gas Evolution Investigations ....... 89

1. Mass Spectral Studies of the Products of the Dichromate-Nitrate Reaction in $\mathrm{KNO}_{3}-\mathrm{NaNO}_{3}$ Eutectic.......... 89

2. Determination of Acidic Oxy-Anions in Fused Salts by $\mathrm{CO}_{2}$ Evolution...... 90

C. Acid-Base Relationships in Fused Salts .....: 91

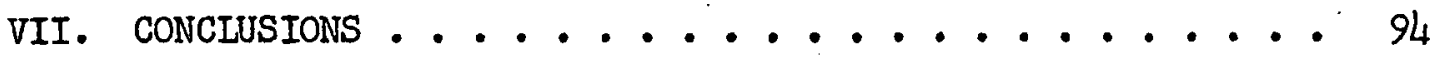

VIII. LITERATURE CITED. . . . . . . . . . 95 
List of Tables

Table

Page

I Reagents Used............. 15

II X-ray Pattern of Cobalt Precipitate. . . . . . 4 I

III Determinations of Formation Constants for Lead-. . Chloro Complexes in $\mathrm{KNO}_{3}-\mathrm{NaNO}_{3}$....... 69

IV Solubilities of Lead Chromate as a Function of Added Bromide ............. 70

$\mathrm{V}$ Determination of Formation Constants for LeadBromo Complexes .......... . 72

VI Standard Mass Spectral Patterns. . . . . . 75

VII Mass Spectral Patterns of Reaction Products. . . 76

VIII Analysis of Reaction Products. . . . . . . 76

IX Sample Calculations. . . . . . . . . 77

$\mathrm{X}$ Determination of $\mathrm{K}_{2} \mathrm{Cr}_{2} \mathrm{O}_{7}$, in $\mathrm{KNO}_{3}-\mathrm{NaNO}_{3}$ Eutectic. . 78

XI Determination of Acidic Oxy-Anions in LiCl+KCl Eutectic.............. 79

XII Qualitative Observations of Reactions in Fused

Salts..................... 80 
List of Figures

Figure

Page

1 Copper Furnace Block. . . . . . . . . . 18

2 Light Tight Furnace Jacket. . . . . . . . . 19

3 Spectrophotometer Furnace Assembly . . . . . . 21

4 optical cells ................. 22

5 High Temperature Spectrophotometer. . . . . . 23

6 Temperature Control Circuit .......... 24

7 Filtration Apparatus for Filling Optical Cells. . . 26

8 Filtration Apparatus for Gross Amounts of Salts . 28

9 Reaction Vessel . . . . . . . . . 29

10 Spectra of Cobalt-Chloride Mixtures, Continuous
Variation Study. . . . . . . 43

11 Continuous Variation Study, Co-Cl System. . . . . W4

12 Spectra of Cobalt-Chloride Mixtures, McConnell-

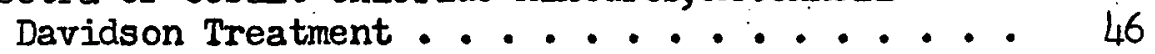

13 McConnell-Davidson Treatment Co-Cl System . . . . 47

14. Spectra of Cobalt-Bromide Mixtures. . . . . . 48

15 Spectrum of $\mathrm{LiNO}_{3}-\mathrm{KNO}_{3}$ Eutectic . . . . . . . 50

16 Spectra of Chromium Salts in $\mathrm{LiNO}_{3}-\mathrm{KNO}_{3} \ldots \ldots 5$

17 Spectrum of Chromate Ion in Aqueous Solution. . . 52

18 Differential Spectrum of $\mathrm{K}_{2} \mathrm{Cr}_{2} \mathrm{O}_{7}$ in $\mathrm{LiNO}_{3}-\mathrm{KNO}_{3}$. . 53

19 Spectra of Silver Nitrate . . . . . . . 55

20 Chromium Salts in $\mathrm{AgNO}_{3}$........... 56

21 Beer's Law Plot, $\mathrm{K}_{2} \mathrm{Cr}_{2} \mathrm{O}_{7}$ in $\mathrm{AgNO}_{3}$ at $300^{\circ} \mathrm{C}$. . . . 57 


\section{List of Figures (Cont'd)}

Figure

Page

22 Molar Extinction Coefficients, $\mathrm{K}_{2} \mathrm{Cr}_{2} \mathrm{O}_{7}$ in $\mathrm{AgNO}_{3}$

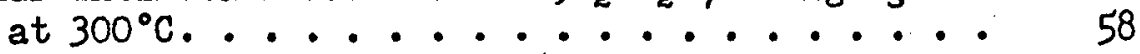

23. Spectra of Chromium Salts in $\mathrm{KNO}_{3}-\mathrm{NaNO}_{3}$..... 59

$24 \mathrm{~K}_{2} \mathrm{Cr}_{2} \mathrm{O}_{7}$ and $\mathrm{K}_{2} \mathrm{CrO}_{4}$ Solutions in $\mathrm{KNO}_{3}-\mathrm{NaNO}_{3} \ldots 6 \mathrm{I}$

25 Beer's Law Plot, $\mathrm{K}_{2} \mathrm{CrO}_{4}$ in $\mathrm{KNO}_{3}-\mathrm{NaNO}_{3}$ at $300^{\circ} \mathrm{C}$. . 62

26 Molar Extinction Coefficients, $\mathrm{K}_{2} \mathrm{CrO}_{4}$ in $\mathrm{KNO}_{3}-\mathrm{NTNO}_{3}$ at $300^{\circ} \mathrm{C}$............ 63

27 Differential Spectra of $\mathrm{K}_{2} \mathrm{Cr}_{2} \mathrm{O}_{7}$ in $\mathrm{KNO}_{3}-\mathrm{NaNO}_{3} \cdot \cdots \quad 64$

28 Spectra of Chromium Salts in LiCl-KCl. . . . . 66

29. Spectrum of $\mathrm{CrCl}_{3}$ in $\mathrm{LiCl}-\mathrm{KCl}$. . . . . . . 67

30 Spectrum of $\mathrm{K}_{2} \mathrm{Cr}_{2} \mathrm{O}_{7}$, $\mathrm{HCl}$ treated, in LiCl-KCl. . . 68

31 F Plots for Lead-Chloro Complexes. . . . . . . 71

32 F Plots of Lead-Bromo Complexes. . . . . . . 73 
Abstract

The present work is concerned with reactions in fused chloride and nitrate systems. The application of absorption spectrophotometric methods has been made to a study of complex ion formation and acid-base reactions in fused salts. For this purpose, a suitable modification of a Beckman D.U. Spectrophotometer was made by replacing the sample compartment with a high temperature furnace.

Several methods for the treatment of spectrophotometric data were investigated with particular reference to their application to complex ion formation in fused salts. The method of Continuous Variation and the method of McConnell and Davidson were applied to the cobalt-chloride system in lithium nitrate-potassium nitrate eutectic, with evaluation of the formation constant for the first complex, $\mathrm{CoCl}^{+}$, in the range of 40 to 300 .

The spectra of various chromium salts were determined in three nitrate melts and also in fused lithium chloride-potassium chloride. In low solute concentrations in $\mathrm{LiNO}_{3}-\mathrm{KNO}_{3}, \mathrm{NaNO}_{3}-\mathrm{KNO}_{3}$ and $\mathrm{LiCl}-\mathrm{KCl}$ melts, the species found was the chromate ion, while in molten $\mathrm{AgNO}_{3}$, the species found was the dichromate ion. An explanation of these observations is put forward, and their significance discussed.

Using the absorption of light by the chromate ion as an "in situ" determination of the solubility of lead chromate as a

$$
3070.0
$$


function of halide ion concentration in $\mathrm{NaNO}_{3}-\mathrm{KNO}_{3}$ melts, formation constants for lead-chloro and lead-bromo complexes have been evaluated. The values obtained for the first two lead-chloro and lead-bromo complexes are $11.3,3.6$ and 13.3 and 6.0 , respectively, with an estimated accuracy of $\pm 20 \%$ for the first formation constants and $\pm 50 \%$ for the second formation constants.

Mass spectral studies of the gaseous products of the reaction between dichromate ion and nitrate ion in fused $\mathrm{NaNO}_{3}-\mathrm{KNO}_{3}$ has shown that the reaction is of an acid-base type, involving formation of a nitronium ion which then reacts with nitrate ion to evolve dinitrogen pentoxide decomposition products. A method for the "in situ" determination of acidic oxy-anions in fused salts by measurement of the carbon dioxide evolved upon the addition of sodium carbonate has been developed and shown to be quantitative.

A number of qualitative experiments in fused salts involving acid-base reactions have been performed, and their gelation to oxidation-reduction processes in the fused salts is discussed. An analogy is dram to a similar relation in aqueous solution. 


\section{INTRODUCTION}

\section{A. Historical Review}

Investigation of the behavior of molten salts has been of interest for many years. Many methods have been used to investigate molten salts as substances in themselves or as solvents for other materials. Some of the methods that have been used extensively are cryoscopy, potentiometry, conductance measurements, density measurements and polarography, to mention but a few. Any attempt to discuss all methods of examining molten salts would be beyond the scope of this work. Several good reviews have been published for this very purpose; ${ }^{2,2}$ as well as several good bibliographies which indicate the amount of work which has been devoted to molten salts. ${ }^{3,4}$

In recent years, much interest has been directed toward the determination of structures of ions in molten salt solutions. One useful method for determining structures of ions is the use of absorption spectroscopy. Investigations using absorption spectroscopy have been carried out by sakat, Sundheim, Gruen and Smith. Sakai has been concerned with measuring the absorption edges of the alkali metal nitrates and halides as well as some heavy metal hal-

' ides. Sundheim and Greenberg have determined the absorption edges and temperature coefficients for shifts in the absorption edges for a variety of substances. They have also investigated the spectral characteristics of halide ion and halogen in chloride media. 
Sundheim and Harrington have investigated the spectra of metal ions of the first transition series in KCl-LiCl eutectic and in thiocyanate media.

Gruen has investigated complex ion formation in fused salt systems. He has shown that cobalt(II) is complexed by chloride ion in $\mathrm{LiNO}_{3}-\mathrm{KNO}_{3}$ eutectic and that the absorption maxima and halfwidths of the peaks of metal ions in this melt are comparable to those found in aqueous solution. 'Gruen and MacBeth have investigated the structure of the $\mathrm{NiCl}_{4}=$ ion in $\mathrm{LiCl}-\mathrm{KCl}$ eutectic. ${ }^{10}$ Gruen has also investigated the spectra of uranium and transuranic elements in $\mathrm{KCl}-\mathrm{LiCl}$. ${ }^{11,12}$.

Smith and Boston have also studied the nickel-chloro complex in LiCl-KCl. ${ }^{13}$ They have also investigated the structure of the nitrate ion and the nitrite ion in $\mathrm{LiNO}_{2}-\mathrm{LiNO}_{3}$ mixtures and the structure of the chromate ion in nitrate and chloride media. ${ }^{14}$ They concluded that the spectra of these ions are the characteristic electronic spectra which have been found for these ions in non-fused salt media.

Duke and Iverson have studied acid-base reactions in molten salts by studying the kinetics of the reaction of dichromate with nitrate ion in $\mathrm{KNO}_{3}-\mathrm{NaNO}_{3}$ eutectic. ${ }^{26}$ They have also studied halide complexes of lead and cadmium in the same eutectic by determining the increase in solubility of the respective chromates as a function of halide-ion concentration. 
All of these investigations have been directed toward determining the species present in a molten salt and the mechanism by which these species are formed.

\section{B. Statement of Problem}

The literature available on fused salt studies indicates a need for a better understanding of the processes which occur in fused salt solutions. The existence of complex ions has been demonstrated by many workers in this field but little progress has been made in the evaluation of formation constants of complex ions. A complex ion is considered to exist when a measurable effect is noted experimentally. The use of spectrophotometric methods for evaluating formation constants of complex ions in aqueous solution is well known and quite useful.

The problem of acid-base relationships in fused salts is one which is not well defined since the characteristics of acids and bases have been only fleetingly defined. The interrelation of acid-base reactions and oxidation-reduction processes in aqueous solution is known but no such interrelation is known for these reactions in fused salts.

This investigation is therefore an attempt to utilize spectrophotometric methods to study complex ions, formation constants of complex ions and acid-base reactions in fused salts. A preliminary study of methods available as well as a detailed study of methods 
found useful is included. In addition to the spectrophotometric methods used, gas evolution techniques are investigated and these techniques used to study acid-base reactions. A qualitative study is made of the interrelation of acid-base behavior and oxidationreduction processes. 
II. THEORY

\section{A. Fused Salts as Solvents}

Salts in the molten state differ greatly in solvent properties from solvents such as water or organic liquids. The first and most obvious difference is that in general the temperatures necessary to maintain salts in the liquid state are much higher than those encountered for aqueous or organic solutions. Salts such as the nitrates and halides of the alkali metals are highly ionic in nature. The theoretical treatment of fused salts such as these is, therefore, completely different from that used for water or organic liquids. Several attempts have been made to describe the liquid state of molten salts, with varying degrees of success. ${ }^{17,18}$

Nitrate. melts have an advantage in studying complex ions as the melts are considered not to interact to any appreciable extent with foreign ions dissolved in them. These nitrate melts may be considered, therefore, to be of a non-complexing nature, ${ }^{9}$ in contrast with halide media in which it has been show that definite complex ions exist. In aqueous solution, the tendency of nitrate Ion to form complex lons with cations is known to be much less than that of halide ions. Therefore, the spectra of cations obtained in nitrate media is considered to be that of the cation itse If and not that of a complex ion. This has been borne out by the work of Gruen. Gruen found that the maxima of absorption in fused $\mathrm{LiNO}_{3}-\mathrm{KNO}_{3}$ eutectic 
for ions such as cobalt(II), nickel(II) and iron(III) was very similar to the maxima found in aqueous solutions containing perchloric acid. A slight shift in the wavelength of the maxima was noted but was attributed to temperature effect.

Molten salts, in one sense, are easier to treat as solvents than comparable aqueous solutions as molten salts do not dissociate as water does, into hydronium ions and hydroxyl ions. This is one less factor that must be considered in certain reactions. As a result, the identification of certain species present in molten salt solutions should be less complicated than the identification of species in aqueous solution. Molten salt media have the further advantage that many substances are appreciably more soluble in molten salts than in aqueous media because the temperature is much higher and the molten salts are highly. ionic in nature.

\section{B. High Temperature Acids and Bases}

Much has been written about theories of acids and bases in aqueous and non-aqueous solvents. The Brönsted definition of acids and bases characterizes an acid as a proton donor and a base as a proton acceptor. The Lewis Electronic Theory of acids and bases uses the transference of a pair of electrons as the criteria for acidity and basicity. An acịd, under the Lewis theory, will accept a pair of electrons while a base will donate a pair of elec-

trons. 19 The Lux-Flood concept of acids and bases defines an acid as a material which accepts or gains an oxide ion while a base donates or loses an oxide ion.

$$
\text { arsta }
$$


Even from this very brief description of some acid-base concepts it seems apparent that the most fruitful concept to use depends upon the system which is being referred to. For example, the Brönsted theory would not apply in molten salts, such as the alkali nitrates, as hydrogen ion does not exist in them. On the other hand, the Iux-Flood concept would not apply in a non-polar solvent such as carbon tetrachloride as oxide ion does not appear to exist in such an environment.

Moeller has pointed out that there are many common examples of high temperature acids and bases which are frequently encountered. $^{21}$ Metaphosphate ion can be considered a high temperature acid in the reactions it gives in the metaphosphate bead tests. Alkali pyrosulfates and acid sulfates are high temperature acids used to "bpen" basic ores while carbonates, hydroxides and metal oxides are used as basic fluxes for acidic ores. Each of these examples can be explained by the Lux-Flood concept of exchange of oxide Ion or by the Lewis electronic theory where an electron pair is transferred, in this case attached to the oxide ion.

The Lux-Flood concept seems to be the most fruitful for the work in fused salts in this investigation. For example, the reaction between dichromate ion and carbonate ion can be written as

$$
\mathrm{Cr}_{2} \mathrm{O}_{7}=+\mathrm{CO}_{3}=\longrightarrow 2 \mathrm{CrO}_{4}=+\mathrm{CO}_{2}(\text { gas })
$$

The dichromate ion acts as a Lux-Flood acid by abstracting an oxide

\section{$35 \%$ 018}


ion from the carbonate ion to form two chromate ions and carbon dioxide. A system of relative acidities may be defined. The stronger the acid the more readily it will accept oxide ions. If an acid abstracts an oxide ion from a base, the conjugate acid formed from this reaction must be a weaker acid than the original acid. In the above reaction, $\mathrm{CO}_{2}$ is a weaker acid than the dichromate ion.

Flood and Forland have reported conclusions similar to the above on acidic and basic properties of metal oxides. 22 They found that $\mathrm{B}_{2} \mathrm{O}_{3}$ reacted with $\mathrm{Li}_{2} \mathrm{CO}_{3}$ and $\mathrm{NaCO}_{3}$ melts giving of carbon dioxide. By measuring the amount af carbon dioxide evolved, they were able to ascertain a change from $\mathrm{B}_{2} \mathrm{O}_{3}$ to $\mathrm{BO}_{2}{ }^{-}$or $\mathrm{BO}_{3}{ }^{-3}$. Duke has used this concept of acids and bases to explain the reaction of dichromate ion with nitrate ion in fused $\mathrm{KNO}_{3}-\mathrm{NaNO}_{3}$ eutectic. $^{15}$

\section{Theory of Light Absorption}

The fundamenta]. equation for the absorption of radiant energy is the Bunsen equation which can be written as:

$$
I=I_{0} 10^{-a b c}
$$

where $I$ is the intensity of the transmitted radiation, $I_{0}$ is the intensity of the incident radiation, $"{ }_{2} \|$ is the absorptivity, "o $"$ is the thickness of the sample and "c" is the concentration of the absorbing species. The Bunsen equation reduces to Beer's Law, in the case of optical measuroments:

$$
A=\epsilon b c
$$


where $A$ is the absorbance, defined by $\log _{10}\left(I_{0} / I\right)$, in $n$ is the cell thickness, $\epsilon$ is the molar extinction coefficient if "c" is the concentration expressed in moles per liter. This equation applies for monochromatic light, but since this is difficult to achieve experimentally, a narrow region of the spectra is used. Beer's Law generally does hold for a sufficiently narrow portion of the spectra to permit verification and application. Beer's Law holds only for species in solution, solid, liquid or gaseous, and in practice the absorbance must be corrected for refraction and reflection losses.

\section{Method of Continuous Variation}

Job has shown that "n" can be determined in the equi-

librium

$$
A+n B \underset{A B}{A B}
$$

by mixing solutions of the same molar concentration of $A$ and $B$ in varying proportions and by measuring some suitable property of the system. The difference, $Y$, between the value of the selected property and the corresponding value of the property calculated for no reaction between $A$ and $B$ is plotted against the composition. The resulting curve has either a maximum or minimum which bears a simple relation to " $n$ ". Vosburgh and Cooper have extended the Method of Job. 24 They show that the absorption of monochromatic light is a suitable property to measure for obtaining the composition of the complex in the reaction above. 
It $x$ liters of $B$ and I-x liters of $A$, each of concentration $m$ are mixed, with no appreciable volume change, and $c_{1}, c_{2}$ and $c_{3}$ are the concentrations of $A, B$ and $A B_{n}$ respectively, after reaction has taken place, the following equations apply:

$$
\begin{aligned}
& c_{1}=m(1-x)-c_{3} \\
& c_{2}=m x-n c_{3} \\
& c_{1} c_{2}^{n}=k c_{3}
\end{aligned}
$$

The condition for a maximum or minimum in the curve of $c_{3}$ plotted versus $\mathrm{x}$ is:

$$
\mathrm{dc}_{3} / \mathrm{dx}=0
$$

By differentiating equations (1), (2) and (3) and combining, the following equation results :

$$
\mathrm{n}=\mathrm{x} / 1-\mathrm{x}
$$

Determination of the value of $\mathrm{x}$ for which the measured property is a maximum or a minimum will then permit the calculation of " $n$ ". Vosburgh and Cooper extended this treatment to more than one complex ion in a series of reactions of $B$ with $A$. This method is valid only if the complex $A B_{n}$ has an extinction coefficient not equal to that of $\mathrm{A}$.

\section{E. McConnell-Davidson Technique of Evaluating Formation Constants of Complex Ions}

Burns and Hume have modified the McConnell-Davidson technique $^{25}$ to evaluate the first two formation constants for indiumbromide complexes. 26 The evaluation of the first formation constant of the reaction of bromide ion with indic ion, 


$$
k_{1}=\frac{\left[\operatorname{InBr}{ }^{2}\right]}{\left[\operatorname{In}^{+3}\right]\left[\mathrm{Br}^{-}\right]}
$$

was accomplished by using the following expression:

$$
\frac{a b}{A_{0}-A_{a}-A_{b}}=\frac{1}{\left(\epsilon_{a}-\epsilon_{a}-\epsilon_{b}\right) k_{1}}+\frac{a}{\epsilon_{a}-\epsilon_{a}-\epsilon_{b}}
$$

This expression holds at a specific wavelength. In equation (2), $\epsilon_{a}, \epsilon_{a}$ and $\epsilon_{b}$ are the molar extinction coefficients of the complex, the indic ion and the bromide ion respectively while $a$ and $b$ are the analytical concentrations of indic ion and bromide ion. $A_{0}$ is the observed absorbance at the particular wavelength while $A_{a}$ and $A_{b}$ are the absorbances of separate solutions of indic ion and bromide ion at concentrations of $\mathrm{a}$ and $\mathrm{b}$ respectively. The concentration, $a$, is varied, while the concentration, $b$, is held constant. The concentration of the indic ion, $a$, is always maintained larger than that of bromide ion, $b$, to ensure that only the first complex, InBret will form.

A plot of $\frac{a b}{A_{0}-A_{a}-A b}$ versus "a"results in a straight line and the ratio of the slope $\frac{1}{\epsilon a^{-} G^{-} \in b}$ to the intercept $\frac{1}{\left(\epsilon_{a}-\epsilon_{a}-\epsilon_{b}\right) k_{1}}$ being equal to $k_{1}$. Evaluation of formation constants of higher complexes was done by further modification of equation (2).

Adaptation of this method to other complexes is quite straightf orward. 
F. Spectrophotometric Determination of Formation Constants for Complex Ions Using Sparingly Soluble Salts

Duke and Iverson have shown that if a sparingly soluble salt such as lead chromate is dissolved in a nitrate melt, addition of halide ion results in increased solubility of lead chromate by complexing part of the lead ion in solution. ${ }^{16}$ They have shown that if lead complexes of the type $\mathrm{PbX}_{\mathrm{n}}^{2 \mathrm{n}}$ are formed, the solubility of the lead chromate should vary with the halide ion concentration according to the following expression:

$$
S=\left[K_{S p}\left(1+\beta_{1}\left[X^{-}\right]+\beta_{2}\left[X^{n}\right]^{2} \cdots \beta_{n}\left[X^{-n} I^{n}\right)\right]^{1 / 2}\right.
$$

where $S$ is the solubility of lead chromate, and $K_{s p}$ is the solubility product of lead chromate in the pure eutectic, $\mathrm{KNO}_{3}-\mathrm{NaNO}_{3}$. $\beta_{n}$ is the total formation constant for the nth lead halide complex. The formation constants are evaluated by the graphical method of successive intercepts. The solubilities of lead chromate as a function of halide ion concentration were determined by drawing off samples and analyzing for chromate and halide ion.

A somewhat different approach can be made spectrophotometrically. The spectrum of chromate is well known in nitrate media so one can analyze, "in situ", for chromate ion. The solubilities can, therefore, be easily calculated for known additions of halide ion. Unfortunately, not all metal chromates have solubilities with the range of measurement spectrophotometrically. Excess metal ion can be added, however, to depress the chromate ion concentration, 
of a soluble chromate, to a measureable value. This addition complicates the calculation of the formation constants.

If excess metal ion is present, the amount of chromate ion will be determined by the solubility product.

$$
\mathrm{K}_{\mathrm{sp}}=\left[\mathrm{M}^{+2}\right]\left[\mathrm{CrO}_{4}=\right]
$$

If halide ion is added, the following expression will hold true:

$$
[\mathrm{M}]_{\text {total }}=\left[\mathrm{M}^{+2}\right]+\left[\mathrm{MX}^{+}\right]+\left[\mathrm{MX}_{2}\right]+\ldots \cdot\left[\mathrm{MX}_{\mathrm{M}}^{2-\mathrm{n}_{1}}\right]
$$

Letting

$$
\begin{aligned}
& \mathrm{k}_{1}=\frac{\left[\mathrm{MX}^{+}\right]}{\left[\mathrm{M}^{+2}\right][\mathrm{X}]} \\
& \mathrm{k}_{2}=\frac{\left[\mathrm{Mx}_{2}\right]}{\left[\mathrm{MX}^{+}\right][\mathrm{X}]} \\
& \mathrm{k}_{3}=\frac{\left[\mathrm{Mx}_{3}\right]}{\left[\mathrm{Nx}_{2}\right][\mathrm{X}-]}
\end{aligned}
$$

and substituting in equation ( 3 ) results in

$$
[M]_{\text {total }}=M^{4+\infty}\left[J \cdot k_{1}[X]+k_{1} k_{2}[X]^{2}+k_{1} k_{2} k_{3}[X]^{-3}\right] \text { (7) }
$$

Since the metal total is the metal ion present initially, with no halide ion present, plus whatever metal ion dissolved as a result of adding halide ion, the following relationship holds;

$$
[M]_{\text {total }}=\left[\mathrm{M}^{++}\right]_{0}+\left[\mathrm{CrO}_{4}^{=}\right]_{\mathrm{F}}-\left[\mathrm{CrO}_{4}\right]_{0}
$$

Combining equations (7) and (8) results in: 
$\left(\left[\mathrm{M}^{++}\right]_{0}+[\mathrm{CrO}=]_{\mathrm{F}}-\left[\mathrm{CrO}_{4}=\right]_{0}\right) /[\mathrm{M}]_{\mathrm{F}}^{++}=1+\mathrm{k}_{1}\left[\mathrm{X}^{3} \mathrm{k}_{1} \mathrm{k}_{2}[\mathrm{X}]^{2}+\mathrm{k}_{1} \mathrm{k}_{2} \mathrm{k}_{3}[\mathrm{X}]^{3}\right.$ where $\left[\mathrm{M}^{++}\right]_{\mathrm{F}}$ and $\left[\mathrm{CrO}_{4}=\right]_{\mathrm{F}}$ are the final concentrations and $\left[\mathrm{M}^{++}\right]$and $\left[\mathrm{CrO}_{4}{ }^{3}\right]_{0}$ are the concentrations in the pure solvent with no halide ion added. The $\mathrm{CrO}_{4}=$ concentrations are determined spectrophotometrically and the $\mathbb{1}^{+2}$ concentrations calculated from the solubility. product. One may now define $\mathrm{K}_{\mathrm{sp}}{ }^{\prime}$ as:

$$
\mathrm{K}_{\mathrm{sp}}^{\prime}=[\mathrm{M}]_{\text {total }}\left[\mathrm{CrO}_{4}=7\right.
$$

Equation (9) now becomes,

$$
\mathrm{K}_{\mathrm{sp}}^{\prime} / \mathrm{K}_{\mathrm{sp}}=1+\mathrm{k}_{1}[\mathrm{x}]+\mathrm{k}_{1} \mathrm{k}_{2}[\mathrm{x}]^{2}+\mathrm{k}_{1} \mathrm{k}_{2} \mathrm{k}_{3}[\mathrm{x}]^{3}
$$

If a function, $F_{1}$ is def ined by:

$$
F_{1}=\frac{\frac{K_{s p}^{\prime}}{K_{s p}}-1}{[x]}
$$

and $F_{1}$ is plotted versus $\left[X_{-}\right]$the halide ion concentration, the intercept of the function, as $\left[\mathrm{X}^{-}\right]$goes to zero, will be $\mathrm{k}_{1}$. If $\mathrm{F}_{2}$ is defined as $\left(F_{1}-k_{2}\right) /[X-]$, the intercept of the plot of $F_{2}$ versus $[X]$ will equal $k_{1} k_{2} \cdot F_{3}$ would be a similar function giving $k_{1} k_{2} k_{3}$. In this manner the formation constants of successive complexes of halide ion with metal ion may be calculated. 


\section{MATERIALS AND APPARATUS}

\section{A. Materials}

All chemicals used were of reagent grade and were used without recrystallization. The purification of the solvent salts such as $\mathrm{LiNO}_{3}, \mathrm{KNO}_{3}, \mathrm{NaNO}_{3}, \mathrm{AgNO}_{3}, \mathrm{LiCl}$ and $\mathrm{KCl}$ will be described in detail later. All other chemicals except for $\mathrm{Co}\left(\mathrm{NO}_{3}\right)_{2} \cdot 6 \mathrm{H}_{2} \mathrm{O}$, $\mathrm{Cd}\left(\mathrm{NO}_{3}\right)_{2} \cdot 4 \mathrm{H}_{2} \mathrm{O}$ and $\mathrm{CrCl}_{3} \cdot 6 \mathrm{H}_{2} \mathrm{O}$ were vacuum dried at $110^{\circ} \mathrm{C}$. The hydrated salts were vacuum dried at room temperature followed by vacuum drying at $110^{\circ} \mathrm{C}$, as the hydrates melted below $110^{\circ} \mathrm{C}$. Table I gives the chemicals used, the manufacturer and the grade of the reagent.

\section{Table I}

Reagents Used

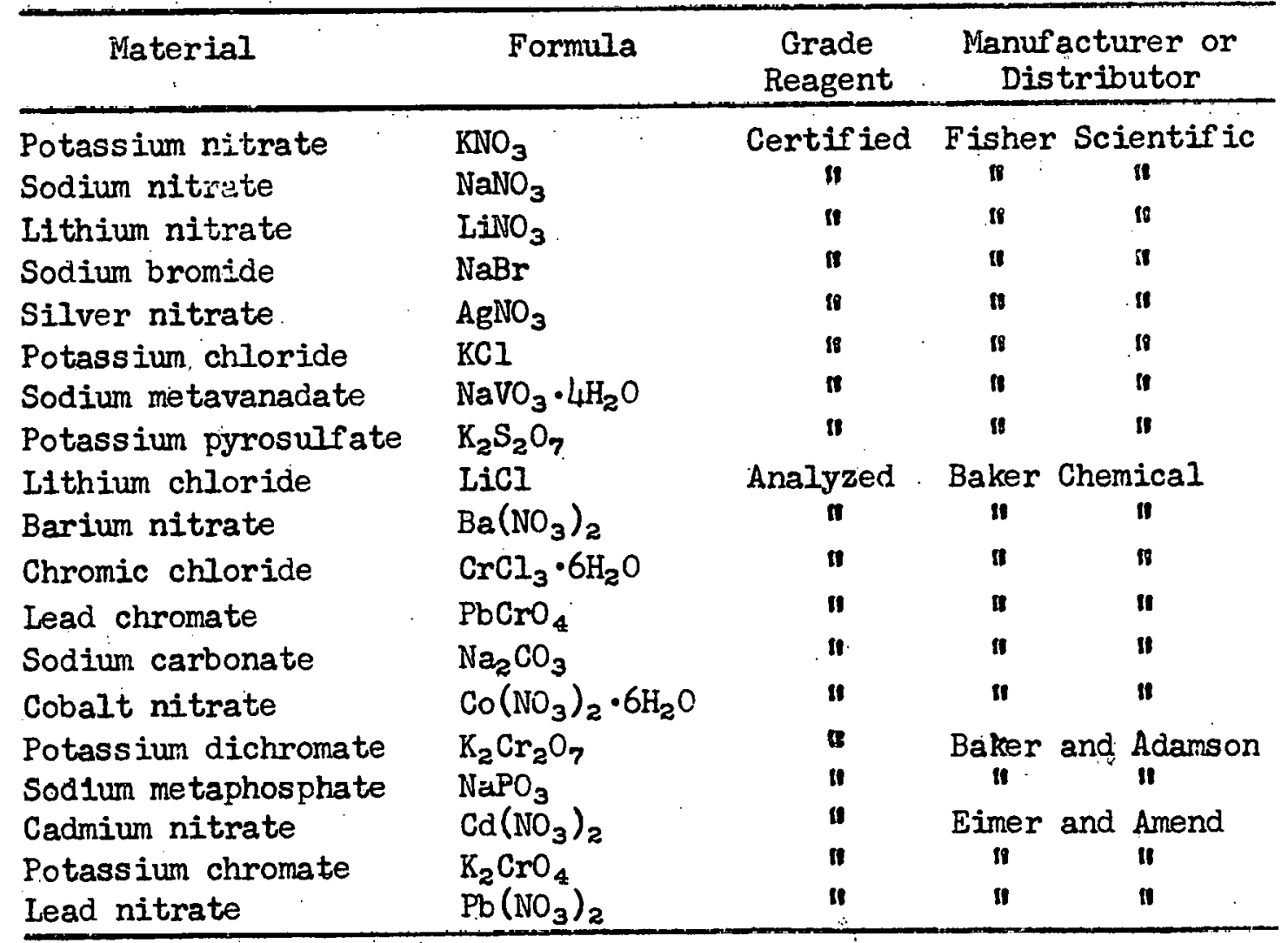


Gases used in this investigation were hydrogen chloride, supplied by 0lin Matheson, and argon and nitrogen, supplied by Linde Air Products. The gases were used as supplied with no further purification.

\section{B. Apparatus}

\section{High Temperature Spectrophotometer.- Various high} temperature spectrophotometers have been described in the literature which permit the taking of spectral measurements in fused salts. ${ }^{13,27,28}$ As the design of an instmument of this type is dependent upon individual preferences and needs, it is necessary to describe, in detail, the instrument used in this investigation. Essentially, the instrument is a spectrophotometer with the sample compartment replaced by a furnace capable of maintaining samples at high temperatures while permitting the passage of light from a monochromator, through the sample, and onto a photocell.

The furnace consists of two copper blocks $6.5 \times 6.5 \times 3.25$ inches, with two faces machined smooth to increase thermal flow. Copper was chosen because of its high thermal conductivity. The specific heat of copper is 0.0963 calories per gram at $200^{\circ} \mathrm{C}$. Two wells were machined into the smooth surface of each of the two copper blocks so that when the blocks were placed together the wells formed two sample compartments 1.1 centimeters on a side. A thermocouple well was bored midway between the sample wells. An oval optical 
path was bored through each of the sample wells and the block. The copper blocks were then nickel plated to prevent excessive air oxidation, using the method of Hackerman. Figure 1 depicts the copper furnace block.

Four heaters were constructed by winding Nichrome $V$ wire on grooved Norton 'alundum' cores and covering the core with a smooth layer of refractory cement. These heaters were placed in heater wells bored in the copper furnace blocks. Each heater had a resistance of 7 ohms and was arranged to permit either a series circuit or a series-parallel circuit. In a series-parallel circuit the resistance of the circuit was 7 ohms.

The furmace was enclosed by a light-tight jacket made of 1/4-inch brass plate. The furnace block was placed on a $1 / 2$-inch plate of asbestos which was in turn bolted to a steel plate which was $1 / 2-i n c h$ thick. The steel plate was machined on the bottom with two parallel "fll grooves. These grooves matched two grooves on a similar steel plate. Ball bearings were placed in the "fll grooves to permit easy furnace movement. Stops were placed on each steel plate to allow exact positioning of the furnace. Figure 2 shows the furnace block in the light tight jacket, with a positioning screw used to move the furnace. The positioning screw was later replaced by a slide rod. The furnace jacket was cooled by passing cold water through 1/4-inch copper tubing bolted onto the surface of the fumace jacket. 


\section{COPPER FURNACE BLOCK}

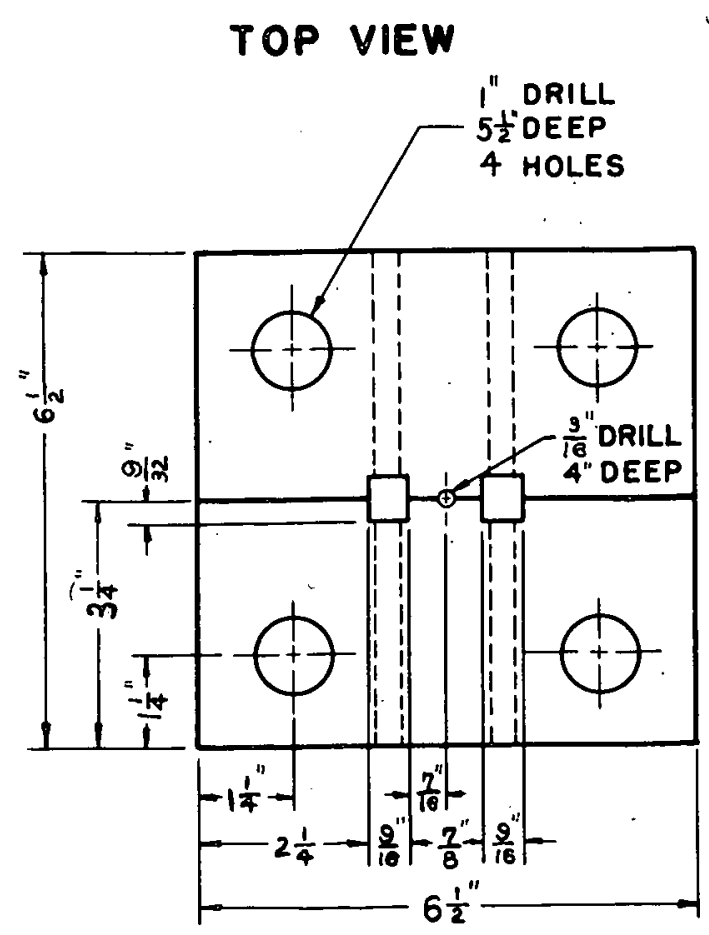

FRONT VIEW
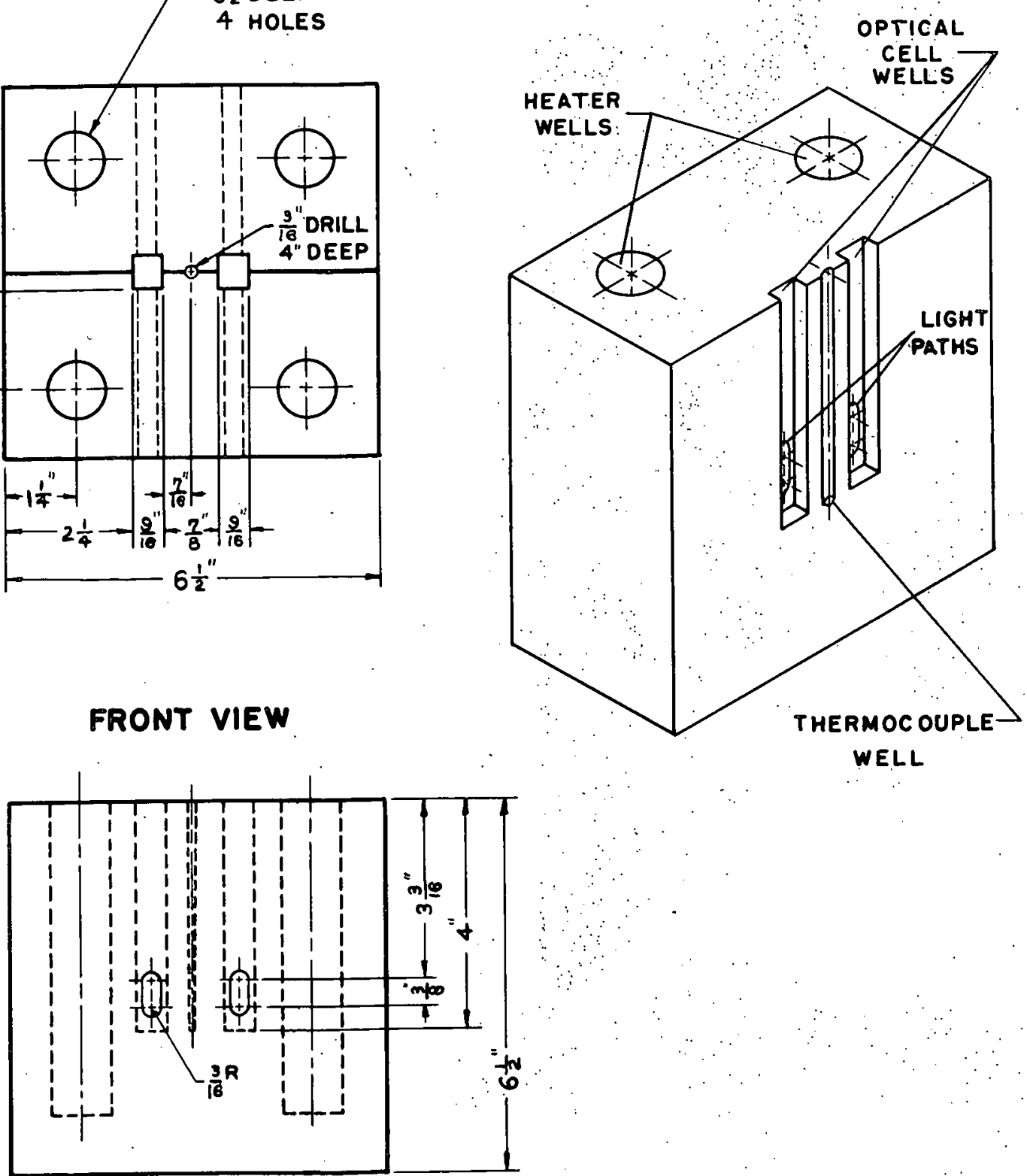

Figure 1

$35 \% \quad 029$ 


\section{LIGHT TIGHT Furnace Jacket}
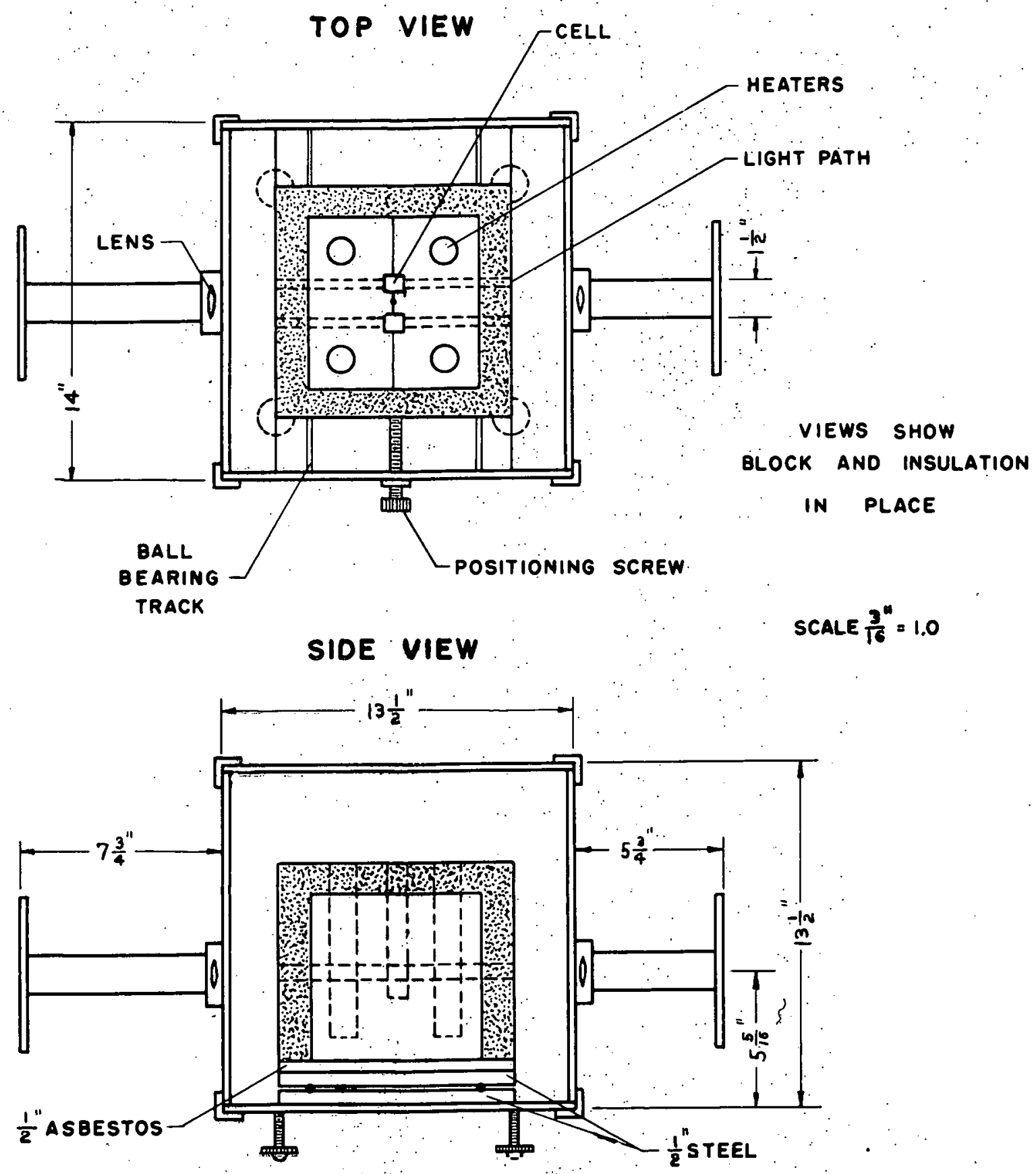

Figure 2 
The optical system of the instrument is shown in Fig. 3. A Beckman D.U. spectrophotometer furnishes the light source and the measuring circuit. A photomultiplier tube was used as the receptor. The incident light from the monochromator was collimated by a quartz lens onto the surface of the optical cells and the transmitted light focussed by a second quartz lens onto the receptor.

Optical cells were conventional Beckman type cells having a quartz tube sealed to the top with a quartz-to-Pyrex seal above the cell. The optical cells, furnished by Pyrocell Manufacturing Company had either a $1 \mathrm{~cm}$. or $2 \mathrm{~mm}$. path length. Figure 4 shows the optical cells.

Figure 5 is a photograph of the complete apparatus.

2. Temperature Controller.- The control of temperatures in the high temperature spectrophotometer is essential for obtaining accurate measurements. A control unit consisting of a Wheelco Model 407 capacitrol, Model 610 pilot amplifier and a multi-tapped 2.0 KVA saturable core reactor (Barber Coleman Company) was used for this purpose. The reactor was tapped at 2.0, 1.5, 1.0, 0.6 and 0.2 KVA with a five-position power switch which allowed selection of the total power applied to the furnace. Figure 6 shows the block diagram of the temperature control circuit. An iron-constantan thermocouple was set in the thermooouple well in lite copper block. The voltage applied to the furnace was proportionally controlled by the unit. The temperature control of the furnace was tested by monitoring 


\section{SPECTROPHOTOMETER Furnace AsSEMbly}

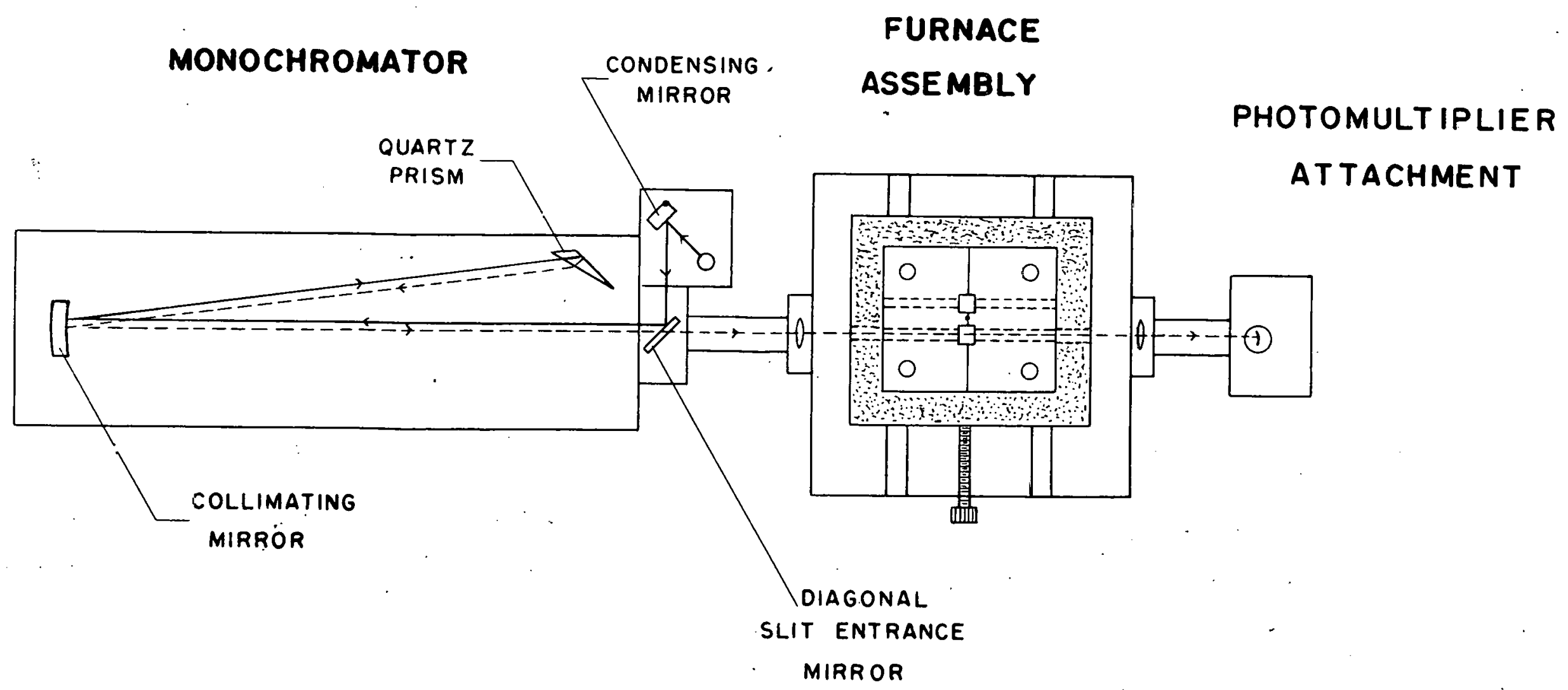

Figure 3 

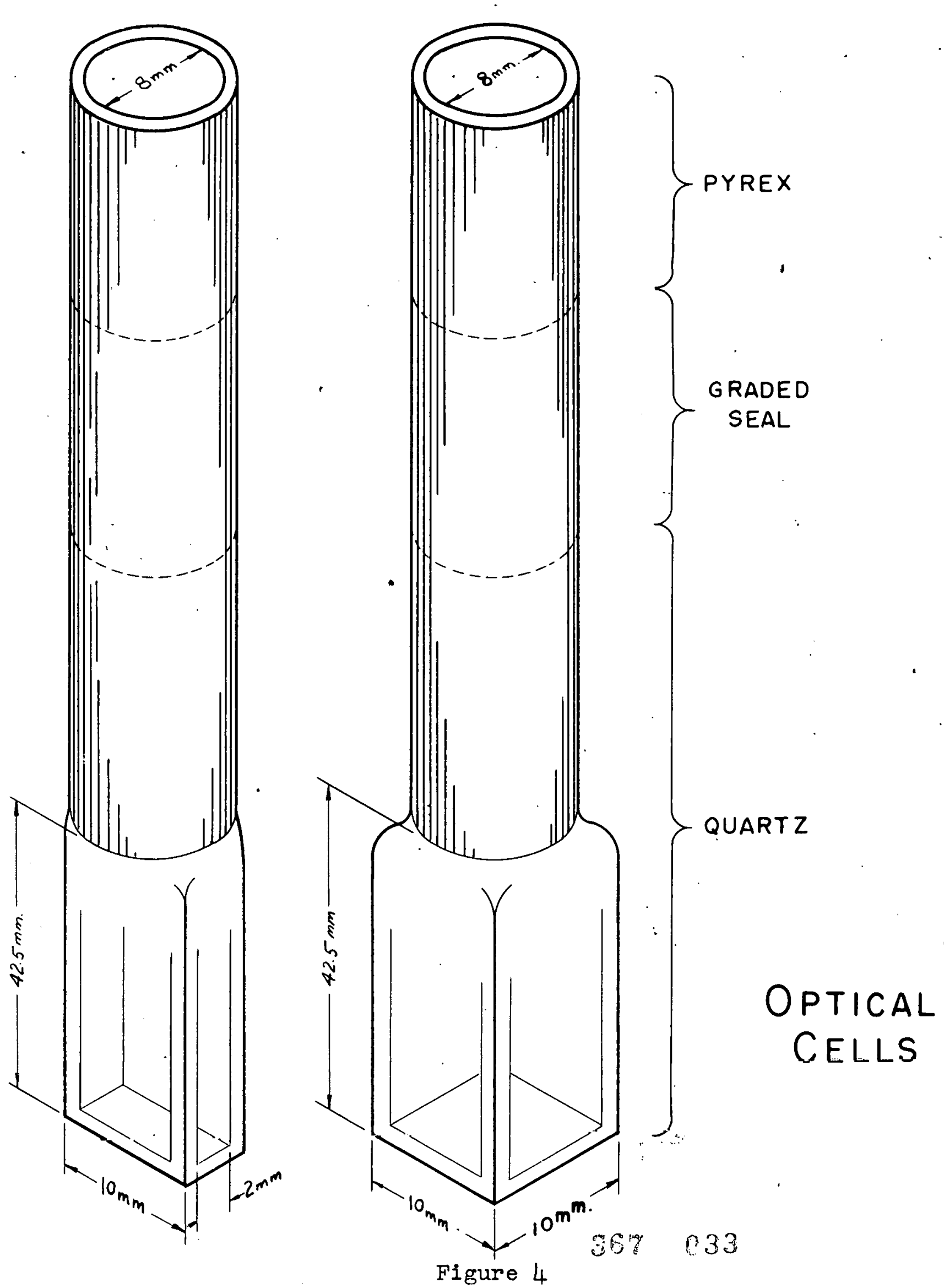


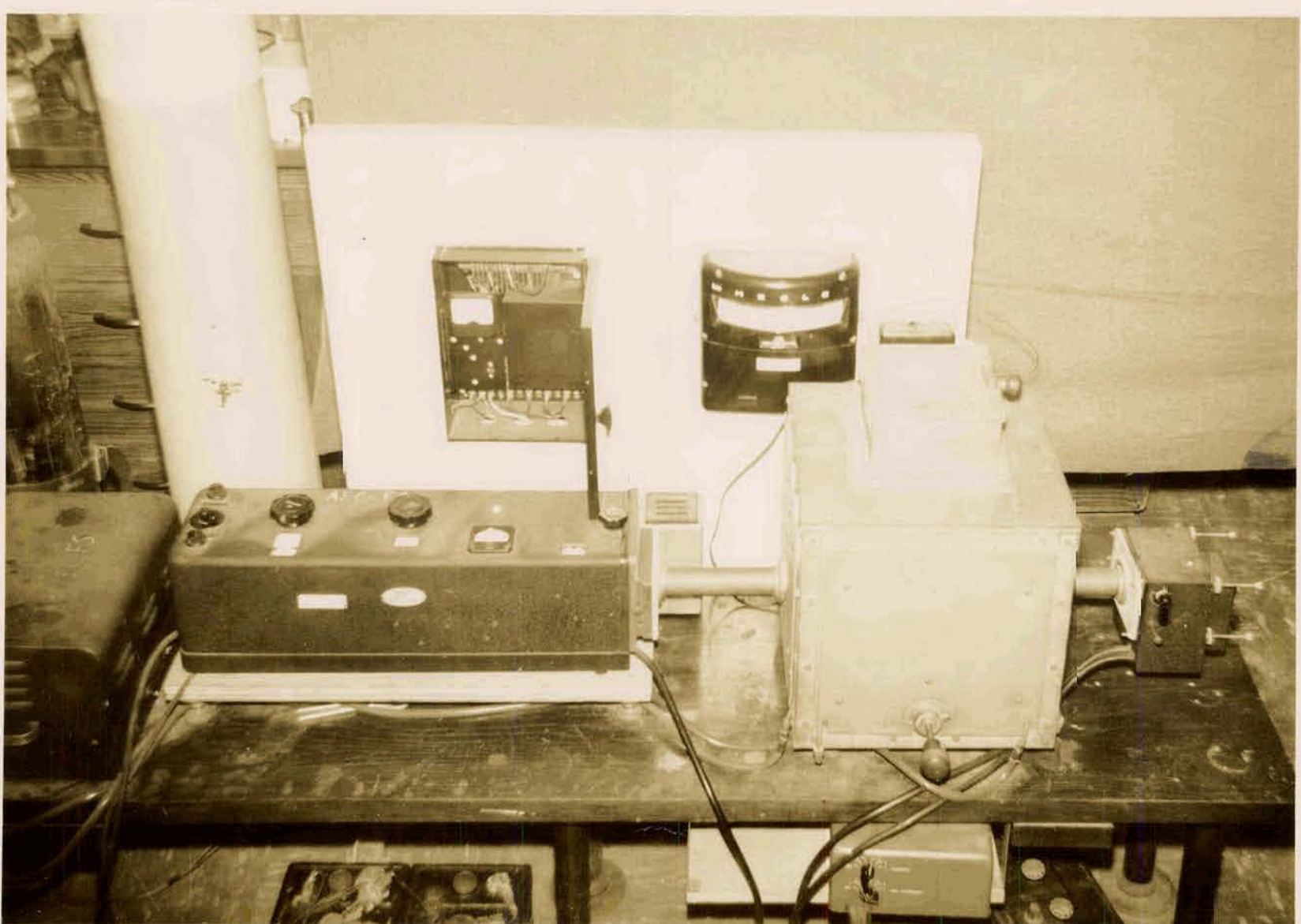

Figure 5

High Temperature Spectrophotometer 
THERMOCOUPLE

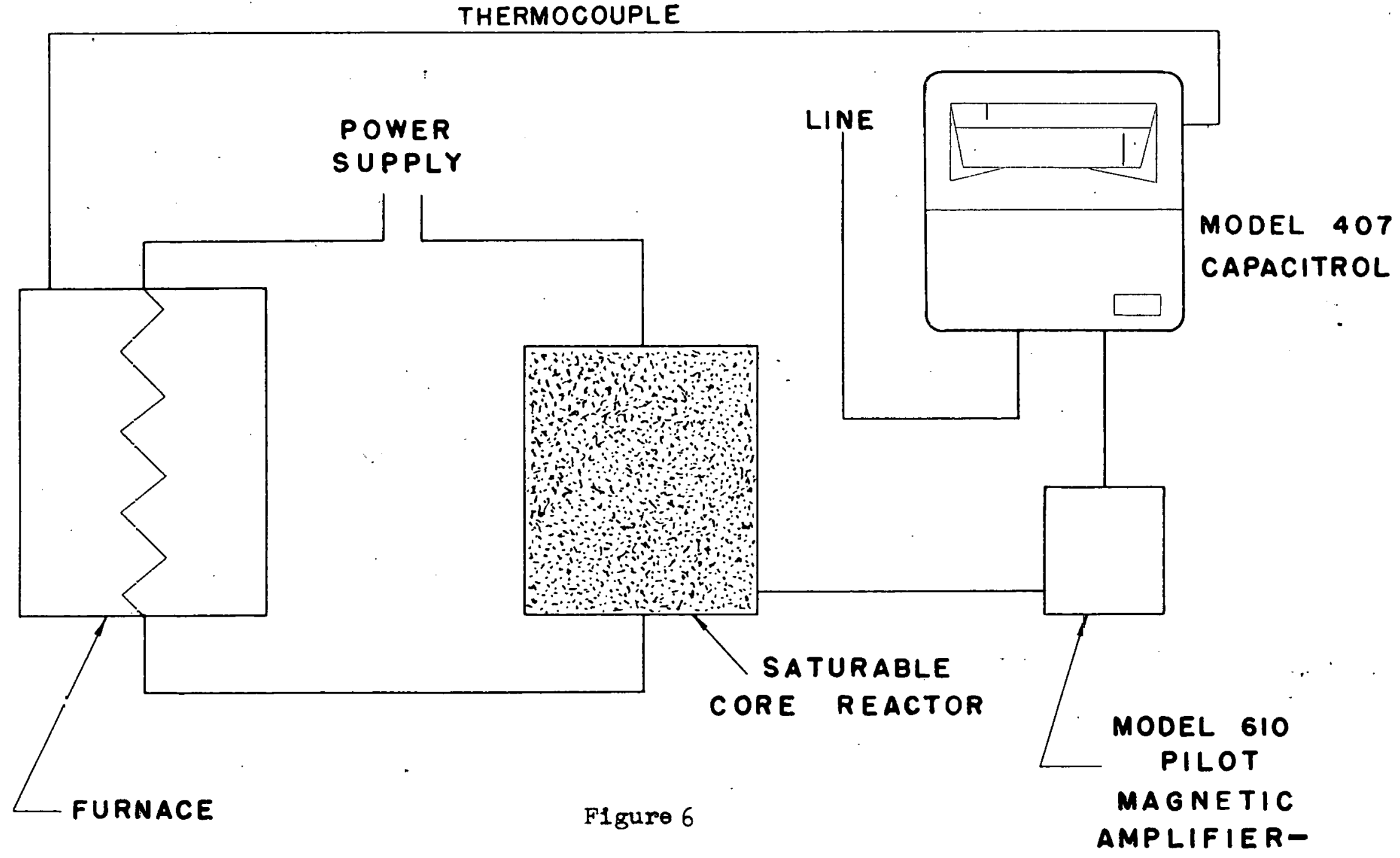

Temperature Control Circuit 
the thermocouple output with a Varian Model 6-1l recorder. The full scale of the recorder was set at 20 millivolts. The chart could be read to 0.03 millivolts which corresponds to a temperature change of $0.5^{\circ} \mathrm{C}$. With the fumace maintained at $190^{\circ} \mathrm{C}$, the temperature remained constant over a 12-hour interval, within the limits of measurement of the recorder. Throughout the entire investigation, the temperature of the furnace was checked using a Rubicon potentiometer Model No.2700 and found to vary less than $0.5^{\circ} \mathrm{C}$ from the temperature set by the control unit, in the range $175^{\circ}-400^{\circ} \mathrm{C}$. The temperature of a sample in the sample wells was also checked and found to be within the same limits of variation.

3. Filtration Apparatus.- In the purification of the fused salts, to be described in detail later, it was found necessary to filter the salts while molten. Two types of filtration apparatus were designed and used.

\section{(a) Filtration into Optical Cells.- Figure 7 shows the appa-} ratus used for filtering molten salts directly into optical cells. The appropriate gas is passed through the molten salts by means of the gas inlet tube and out of the system through a gas bubbler which contained n-dibutyl phthalate. When the drying process was completed, the molten salts were filtered through the glass frit into the optical cell by evaniling the lower part of the apparatus. The cell was then sealed off under vacuum and transferred into the spectrophotometer furnace. The upper portion of the filtration apparatus 


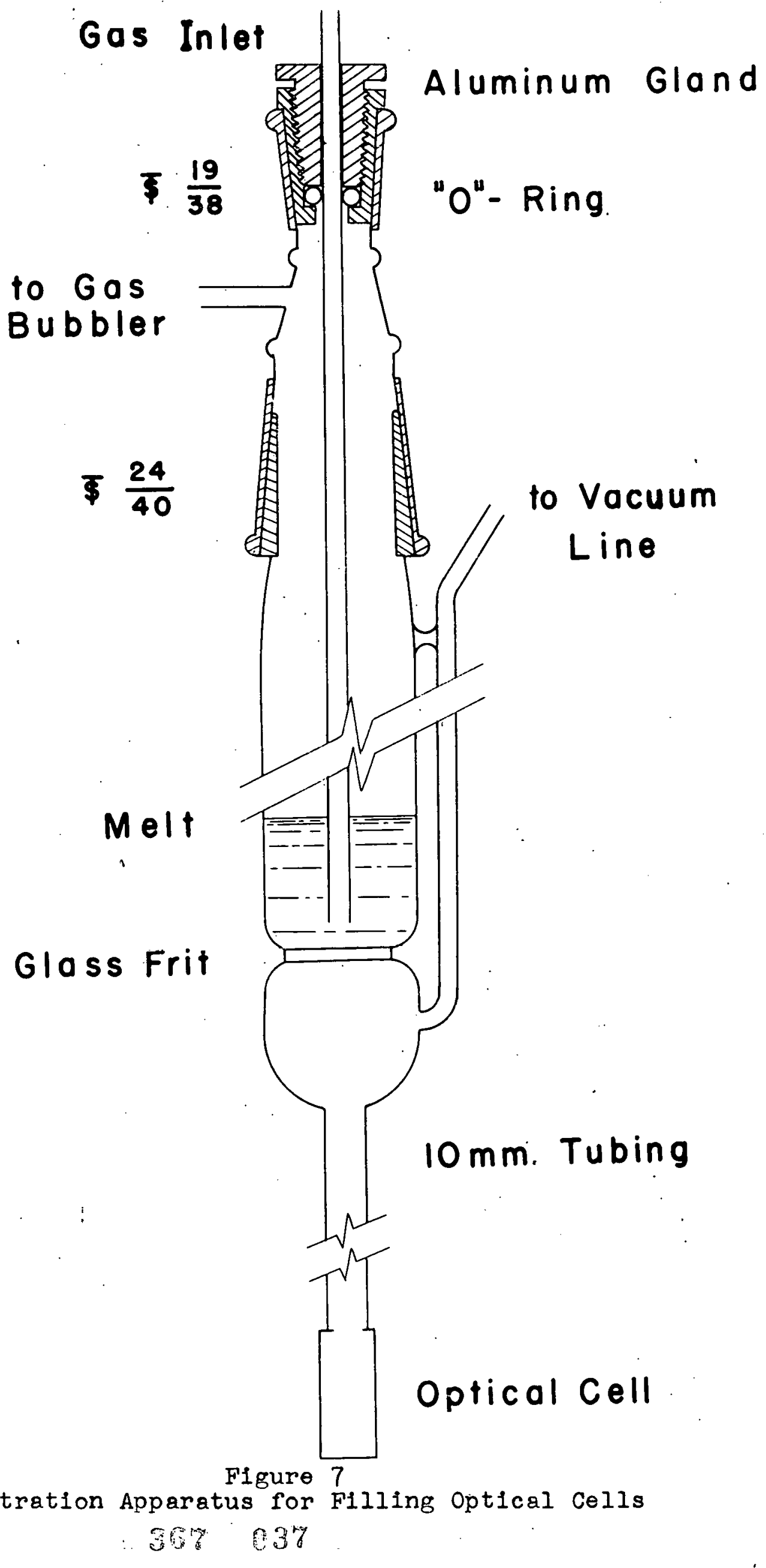


was inside a tubular furnece while the optical cell was maintained at the desired temperature in a Cenco crucible furnace. A gas between the tubular furnace and the crucible furnace was kept small until the sealing off of the cell was desired.

(b) Filtration of Gross Amounts of Salts.- Figure 8 shows the essential parts of the filtration unit which would filter approximately $400 \mathrm{~g}$. of molten salts. Appropriate gasses were bubbled through the salts while molten. The temperature of the filtration unit was maintained by a tubular furnace which surrounded the upper portion of the unit. Evacuation of the apparatus below the frit resulted in filtration of the melt into the Pyrex crucible where it solidified.

4. Reaction Vessel.- In the course of the investigation, it was found necessary to add reagents to an evacuated vessel to permit measurement of the pressures of gases evolved during the reaction. Figure 9 shows the reaction vessel used. Addition of reagents into the evacuated reaction vessel was effected by swiveling the tube to a vertical position. Gas pressures were measured in a static vacuum system by reading a mercury manometer with a cathetometer capable of reading tenths of a millimeter.

\section{Mass Spectrometer.- A Consolidated Electrodynamics} Model 21-620 mass spectrometer, with a modified amplifier circuit, was used to analyze gases produced in this study. Standard mass spectral analys is tubes were used. 


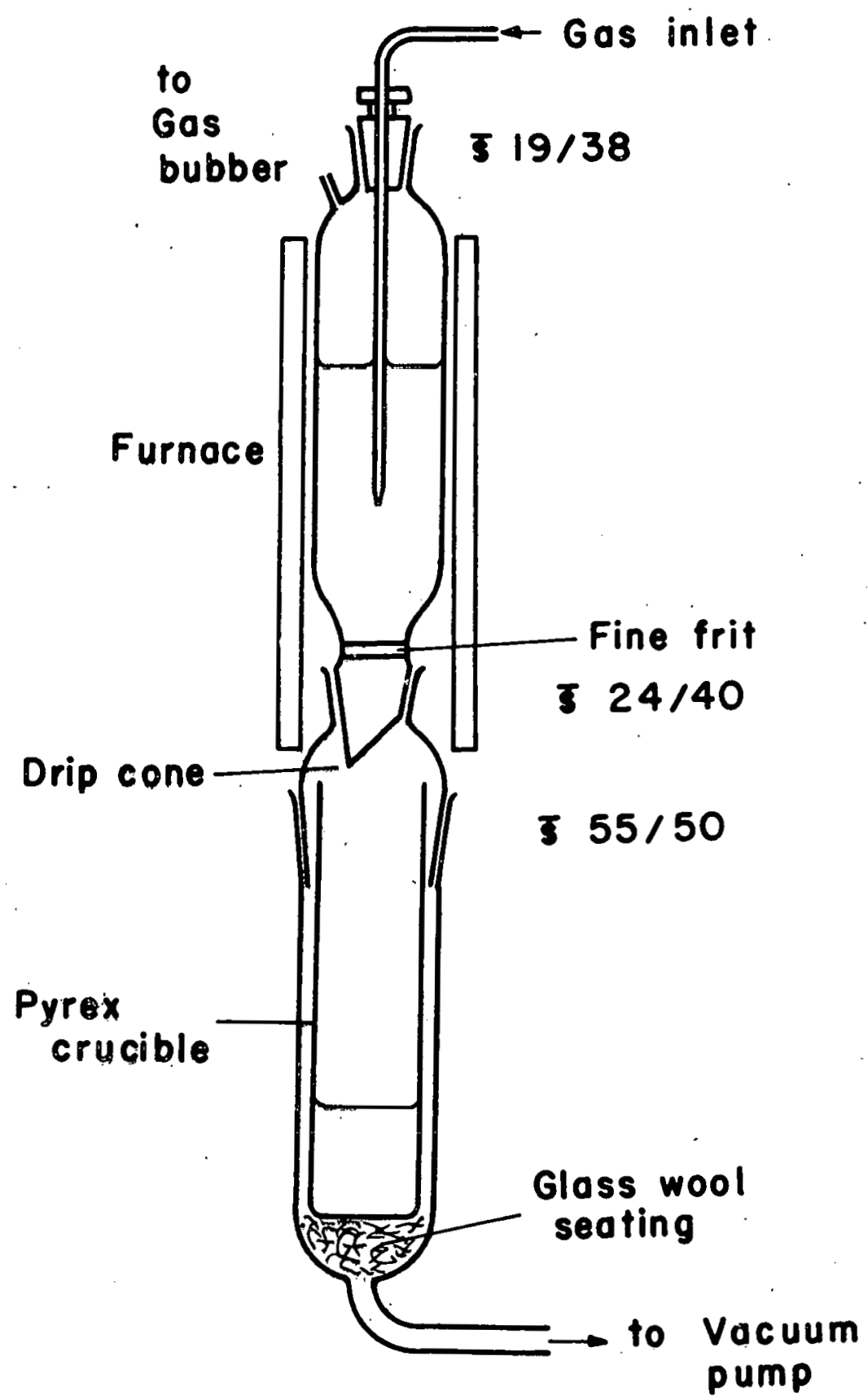

F1 gure' 8

Filtration Apparatus for Gross Amounts of Salts 


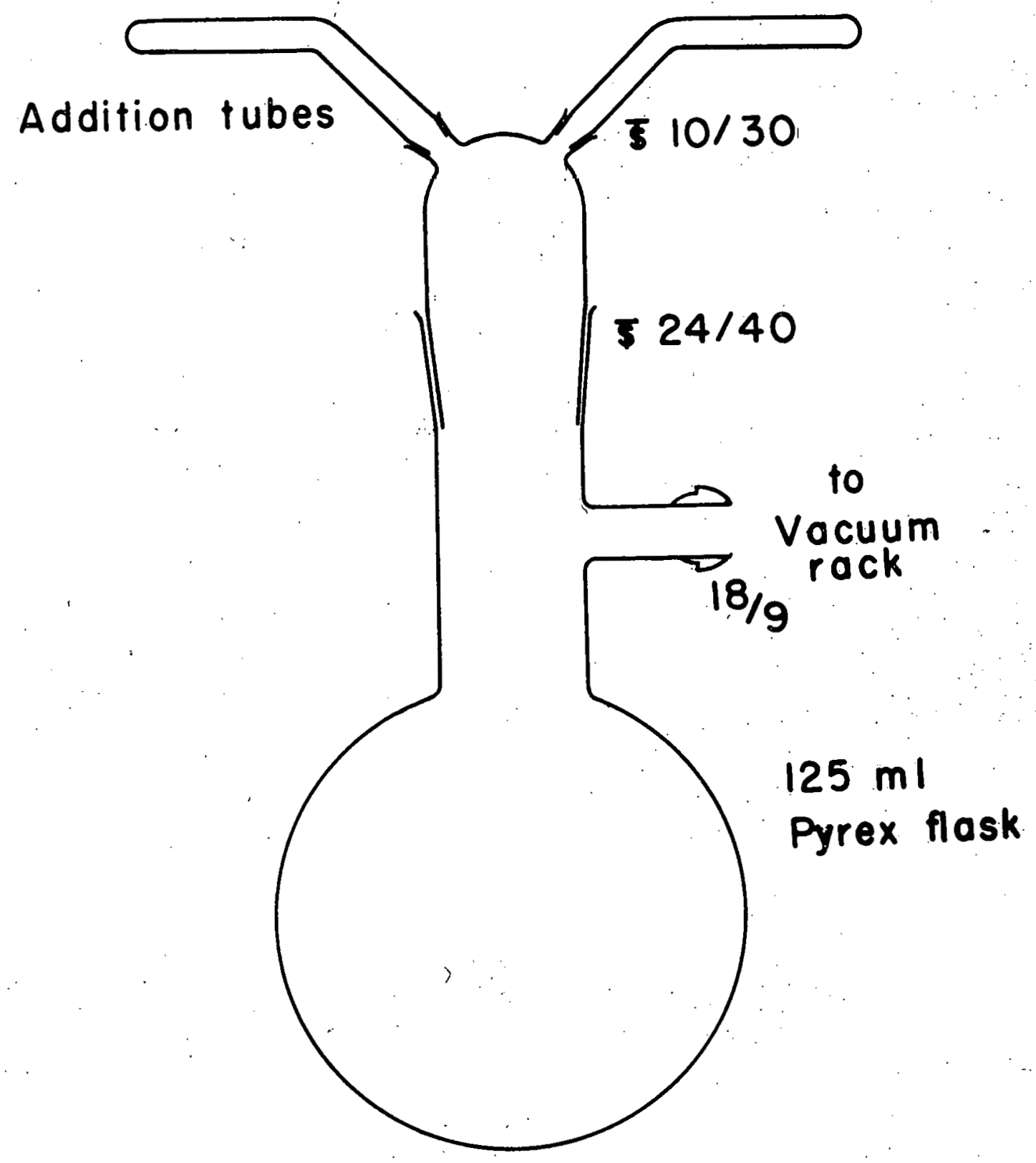

Figure 9

Reaction Vessel 
6. Miscellaneous Apparatus.- The furnaces for the preparation and filtration of salts were constructed by wrapping Vycor tubing with asbestos paper and winding Nichrome wire on the layer of paper. The winding was then covered with a thick layer of alundum refractory cement and a final layer of asbeștos paper.

Cenco crucible furnaces were used for general heating purposes. The vacuum drying oven used was a Labline vacuum oven, No.3620. The ball mill used for crushing and mixing salts was manufactured by the U.S. Stoneware Company, provided with balls and jars of porcelain. 


\section{EXPERTMENTAL PROCEDURES}

\section{A. Preparation and Purification of Salts}

1. $\mathrm{LiNO}_{3}-\mathrm{KNO}_{3}$ Eutectic.- The lithium nitrate-potassium nitrate eutectic was prepared from the separate reagent grade salts. The salts were individually dried at $110^{\circ} \mathrm{C}$ in a vacuum oven for 12 or more hours. The eutectic mixture, consisting of 38.5 mole percent $\mathrm{LiNO}_{3}{ }^{30}$ was then made up by weighing the appropriate amounts of $\mathrm{IiNO}_{3}$ and $\mathrm{KNO}_{3}$ on a triple beam balance and mixing in a ball-mill jar. The ratio of $\mathrm{LiNO}_{3}$ to $\mathrm{KNO}_{3}$, by weight, was $1: 2.336$. The eutectic melts at $139^{\circ} \mathrm{C}$.

The mixture of salts was then fused in the filtration apparatus, Fig. 8, and argon gas bubbled through the melt for 1 hour to remove any water in the salts. The molten eutectic was then filtered and collected in the Pyrex crucible. In general, a black carbonaceous material remained on the glass frit when filtration was complete. The melt solidified in the crucible, was removed by cracking the crucible, crushed with a large mortar and pestle, and stored in screw cap jars.

2. $\mathrm{KNO}_{3}-\mathrm{NaNO}_{3}$ Eutectic.- The potassium nitrate-godium nitrate eutectic, melting at $222^{\circ} \mathrm{C}$, consisted of 50 mole percent $\mathrm{NaNO}_{3}$ or a ratio of $\mathrm{NaNO}_{3}$ to $\mathrm{KNO}_{3}$ of $1: 1.19$ by weight. ${ }^{31}$ The eutectic was prepared and filtered in the manner described above. 
3. LiCl-KCl Eutectic.- The LiCl-KCl eutectic consisted of 58.8 mole percent $\mathrm{LiCl}$ or a ratio of $\mathrm{LiCl}$ to $\mathrm{KCl}$ of $1: 1.23$ by weight. This eutectic melts at approximately $352^{\circ} \mathrm{C} .^{32}$. The salts were individually dried in a vacuum oven at $110^{\circ} \mathrm{C}$, and quickly weighed on a triple beam balance to minimize absorption of water by the LiCl. The salts were mixed thoroughly in the ball mill. The mixture was then placed in the filtration apparatus, Fig. 8, and dry HCl passed over the surface of the powdered salts while the temperature was raised to $400^{\circ} \mathrm{C}$ over a period of 2 hours. Considerable amounts of water were removed as evidenced by the formation of water in the gas outlet tubes.

Once the salts were molten, HCl was passed at a vigorous rate until no more water appeared to be evolved. The passage of HCl was then continued for $I$ hour, followed by a purge with argon to remove traces of $\mathrm{HCl}$ from the melt. The eutectic was then filtered, cooled, crushed and stored in screw-cap jars. As in the case of the $\mathrm{IiNO}_{3}-\mathrm{KNO}_{3}$ eutectic, considerable amounts of black carbonaceous material remained on the glass frit following filtration. The eutectic was then used for the experiments by taking the necessary amount of the eutectic and treating it for a short period of time with $\mathrm{HCl}$ to remove any water absorbed on the surface of the eutectic.

4. $\mathrm{AgNO}_{3}{ }^{-}-$Reagent grade silver nitrate, melting point $212^{\circ} \mathrm{C}$, was used without further purification. 


\section{B. Spectrophotometric Investigations}

\section{Cobalt-Chloro Complexes in $\mathrm{LiNO}_{3}-\mathrm{KNO}_{3}$ Eutectic.-}

The procedure for the preparation of a solution of cobalt nitrate in $\mathrm{LiNO}_{3}-\mathrm{KNO}_{3}$ for spectrophotometric study was comparable to that used in aqueous solutions. The cobalt nitrate was vacuum dried at room temperature followed by vacuum drying at $110^{\circ} \mathrm{C}$. A weighed amount of the cobalt nitrate was mixed in a ball mill with a known amount of eutectic and ground for 12 hours to insure complete mixing. This formed a master mixture whose cobalt content was well known. The cobalt content in the master mixture was checked by electro-analysis. A concentrated master mixture of $\mathrm{KCl}$ in the eutectic was made up in a similar way with the chloride content checked by analysis.

The procedure in making solutions of cobalt ion and chloride ion in the eutectic was straightforward. Calculated amounts of each master mixture were weighed out and these were fused with enough pure eutectic to bring the sample to the proper weight. The weight of the cobalt nitrate and the potassium chloride in the eutectic was taken as negligible for purposes of calculation of concentrations, as each were less than $3 \%$ of the total weight. The mixtures were then fused in $50 \mathrm{ml}$. beakers and poured into preheated optical cells and placed in the spectrophotometer. One half hour was allowed for the solutions to reach temperature equilibrium, at $160^{\circ} \mathrm{C}$. $\overline{\mathrm{L}}_{\mathrm{iNO}}-\mathrm{KNNO}_{3}$ eutectic was used as a blank for the spectrâl measurements. 
Measurements were taken by adjusting the absorbance of the blank to 0.000 and then finding the absorbance of the sample in comparison. When the spectral measurements on the sample were completed, the cells were removed from the spectrophotometer furnace and quickly inverted to drain out the molten salts from the flat optical portion of the cells. If this were not done, the cells very of ten would be cracked when the eutectic solidified. The cells were cleaned with hot distilled water followed either by concentrated nitric acid or hot cleaning solution, potassium dichromate in concentrated sulfuric acid.

Using the above procedure, two techniques were used to obtain information on the cobalt-chloro complexes. The first method used was the method of Continuous Variation while the second method used was that of McConnell and Davidson. Both methods have been described in Part II.

2. Spectral Studies of Chromium Salts in Nitrate Melts.Essentially the same procedure was used to obtain the spectra of $\mathrm{CrCl}_{3}, \mathrm{~K}_{2} \mathrm{CrO}_{4}$ and $\mathrm{K}_{2} \mathrm{Cr}_{2} \mathrm{O}_{7}$ in $\mathrm{LiNO}_{3}-\mathrm{KNO}_{3}$ eutectic, $\mathrm{KNO}_{3}-\mathrm{NaNO}_{3}$ eutectic and $\mathrm{AgNO}_{3}$ as was used for the study of cobalt-chloro complexes in $\mathrm{LiNO}_{3}-\mathrm{KNO}_{3}$ eutectic. In the case of the $\mathrm{IiNO}_{3}-\mathrm{KNO}_{3}$ eutectic and the $\mathrm{AgNO}_{3}$ as solvents, the chromium salts were weighéd on an analytical balance and added directly to a known amount of solvent. A master solution of $\mathrm{K}_{2} \mathrm{Cr}_{2} \mathrm{O}_{7}$ in the $\mathrm{KNO}_{3}-\mathrm{NaNO}_{3}$ eutectic was made up by fusing a known amount of potassium dichromate with a known amount of eutectic 
and filtering the solution. The fusion and filtration ensure homogeneity. A calculated amount of this master mixture was then fused with the appropriate amount of the pure eutectic to give a solution of known concentration of dichromate. In each of the above cases, the samples were fused in a beaker and poured into a preheated optical cell. One half hour was allowed after transference to the spectrophotometer for temperature equilibration. In this manner, both qualitative and quantitative measurements were obtained for the chromium salts in the nitrate melts.

\section{Spectral Studies of Chromium Salts in LiCl-KCI}

Eutectic.- Qualitative measurements were obtained for the spectral characteristics of various chromium salts in the LiCl-KCl eutectic. Because this eutectic absorbs water so strongly, the mixturies were handled in a closed system. $^{33}$ Hydrogen chloride was passed over the surface of prepurified eutectic in the filtration cell, Fig. 7, while the apparatus was slowly heated to the melting point of the eutectic. Two procedures were used to add the chromium salts to the eutectic. In the first, a weighed amount of the chromium salt was added to a known amount of eutectic before HCl treatment and fusion. In the second, the chromium salt was added after HCl treatment and argon purging. In both procedures, HCl was bubbled through the prepurifled melt for at least $1 / 2$ hour after fusion, followed by a $1 / 2$ hour purge with argon. A vacuum was then applied below the frit and the molten salt solution filtered directly into the optical cell. 
The cell was then sealed off under vacuum and transferred to the spectrophotometer furnace. One half hour was allowed for temperature equilibration. A blank of the LiCl-KCl eutectic was used for the spectral measurements. When measurements were complete, the cells were removed from the spectrophotometer and inverted. The molten salts solidified in the Pyrex portion of the optical cell (see Fig. 4). The Pyrex was then cut off and the salts leached out of the optical cell with hot distilled water. The cells were then cleaned as previously described. In normal usage the cells remained unetched unless large amounts of water were present in the salts. Etched cells were discarded and the remaining cells were periodically checked against each other using either the pure eutectic or the same solution in each cell. The cells were matched within the limits of measurement, except where etching had occurred.

4. Spectral Studies of Lead-Halide Complexes in $\mathrm{KNO}_{3}-$ $\mathrm{NaNO}_{3} \cdot-$ In this study, lead chromate was equilibrated with Iiquid $\mathrm{KNO}_{3}-\mathrm{NaNO}_{3}$ eutectic containing halide ion, at $275^{\circ} \mathrm{C}$. A series of known concentrations of halide ion was prepared by direct addition of known amounts of the potassium halide salt to the eutectic solvent. The lead chromate was added to these solutions and the solutions equilibrated for 4 hours at a temperature slightly above $275^{\circ} \mathrm{C}$. The solutions were transferred to the preheated optical cells and placed in the spectrophotometer furnace and held at $275^{\circ} \mathrm{C}$ for 2 hours before measurements were taken. A slight precipitate of lead chromate 
was generally formed in the solution and on the optical surfaces. Corrections were made for the absorbances of the solid lead chromate by measuring the absorbances of the solutions at a wavelength at which chromate ion does not absorb. The $\mathrm{KNO}_{3}-\mathrm{NaNO}_{3}$ eutectic was used as a blank in all cases. In this way the solubility of lead chromate was evaluated as a function of halide ion concentration.

At the temperature of this study, the solubility of lead chromate was such that the absorbance reading obtained for a sample containing no halide ion was approximately 0.50 . A second set of experiments was performed with excess lead ion added to the lead chromate solutions. The excess lead ion repressed the concentration of chromate ion in solution to a point where the absorbance readings could be made over a wider range. The excess lead ion was added by adding weighed amounts of lead nitrate to the eutectic. The concentration of chromate ion was then evaluated as a function of added halide ion.

\section{Gas Evolution Investigations}

1. Mass Spectral Studies of the Gaseous Products of the Dichromate-Nitrate Reaction in Fused $\mathrm{KNO}_{3}-\mathrm{NaNO}_{3}$ Eutectic.- As it has been noted that gases are evolved from a nitrate melt containing dichromate ion, if barium ions are present, an attempt was made to identify these gaseous products. A weighed amount of prepurified $\mathrm{KNO}_{3}-\mathrm{NaNO}_{3}$ eutectic was placed in a reaction vessel, Fig. 9, fused

$$
30 \text { ing }
$$


while under vacuum and brought to $300^{\circ} \pm 5^{\circ} \mathrm{C}$. The system was closed off and potassium dichromate and barium nitrate added, in vacuo, by rotating the addition tubes to a vertical position. The gases evolved were collected in the static system and a sample taken after 30 minutes by closing off a sample tube from the remainder of the system. The system was quickly evacuated, closed off and another sample of the gases taken after a second 30 minute period.

The sample tubes were then used to introduce samples of the gas to the mass spectrometer and the mass spectra of the gases obtained. Standard patterns were taken for $\mathrm{NO}, \mathrm{N}_{2} \mathrm{O}, \mathrm{NO}_{2}$ and $\mathrm{O}_{2}$ on the same instrument. Using these standard patterns and the mass spectra for the gaseous products, the products were identified and the relative amounts of each product determined.

\section{Determination of Acidic Oxy-anions by $\mathrm{CO}_{2}$ Evolution--}

(a) Determination of $\mathrm{K}_{2} \mathrm{Cr}_{2} \mathrm{O}_{2}$ in $\mathrm{KNO}_{3}-\mathrm{NaNO}_{3}$ Eutectic.- The reaction of sodium carbonate with dichromate ion in the $\mathrm{KNO}_{3}-\mathrm{NaNO}_{3}$ eutectic was investigated quantitatively. The reaction flask used was the same as used for the identification of the gaseous products of the dichromate-nitrate reaction, Fig. 9. The volume of the system was calibrated with argon gas, with the reaction vessel at the temperature to be used in the actual reaction. The pressures were measured from a mercury manulieter by a oathetometer capable of reading tenths of a millimeter.

Determinations were performed in the following manner. A weighed amount of eutectic was placed in the reaction vessel 
and fused under vacuum. The system was opened and a carefully weighed amount of $\mathrm{K}_{2} \mathrm{Cr}_{2} \mathrm{O}_{7}$ added and in some cases weighed amounts of $\mathrm{K}_{2} \mathrm{CrO}_{4}$ were also added. $\mathrm{Na}_{2} \mathrm{CO}_{3}$ was placed in one of the addition tubes and the system evacuated and closed off. The $\mathrm{Na}_{2} \mathrm{CO}_{3}$ was then added to the melt, in vacuo, and the pressure of the evolved gas was measured. Knowing the volume of the system, the volume of the melt, the pressure of the system and the temperature of the static system, the number of moles of gas given off was calculated from the ideal gas law. A blank was run, adding $\mathrm{Na}_{2} \mathrm{CO}_{3}$ to the pure eutectic and measuring the pressure of the gas given off. A mass spectral analysis of the evolved gas was performed as described previously. Determinations of $\mathrm{NaPO}_{3}$ and $\mathrm{K}_{2} \mathrm{~S}_{2} \mathrm{O}_{7}$ were attempted in the same manner.

(b) Determination of $\mathrm{K}_{2} \mathrm{Cr}_{2} \mathrm{O}_{7}, \mathrm{NaPO}_{3}$ and $\mathrm{NaVO}_{3}$ in $\mathrm{LiCl}-\mathrm{KCCl}$ Eutectic:- The procedure for determining acidic oxy-anions in LiCl-KCl eutectic was the same as that in the $\mathrm{NaNO}_{3}-\mathrm{KNO}_{3}$ eutectic, except for the drying procedure. In this case, a weighed amount of LiCl-KCl eutectic, predried and prepurified, was added to the reaction vessel. Hydrogen chloride was passed over the surface of the eutectic while the temperature was slowly rajsed to the melting point of the eutectic, over a period of 2 hours. Hydrogen chloride was bubbled for $1 / 2$ hour after the eutectic became molten. The system was maintained at $400^{\circ} \pm 5^{\circ} \mathrm{C}$ and evacuated for 1 hour to remove all dissolved HCl in the melt. The system was then opened, the sample 
added and the system re-evacuated. The length of time the system was open to the atmosphere was less than 2 minutes.

Once the system was evacuated, sodium carbonate was added from an addition tube and the pressure of the evolved gas measured. Dichromate ion, metaphosphate ion and metavanadate ion were determined in this manner. An attempt was also made to determine pyrosulfate ion. The amount of each acidic species present was determined by the number of moles of $\mathrm{CO}_{2}$ given off. Blanks were run on the addition of $\mathrm{Na}_{2} \mathrm{CO}_{3}$ to the chloride eutectic as well as on the addition of each oxy-anion to the chloride eutectic. 


\section{EXPERTMENTAL RESULTS}

\section{A. Spectrophotometric Investigations}

1. Spectral Studies of the Cobalt-Halide Complexes in $\mathrm{LiNO}_{3}-\mathrm{KNO}_{3}$ Eutectic.- (a) Cobalt-Chloro Complexes.- When solutions of cobalt nitrate were made in the $\mathrm{LiNO}_{3}-\mathrm{KNO}_{3}$ eutectic which had been dried at $110^{\circ} \mathrm{C}$, a black precipitate formed upon fusion of the salts. In an effort to identify the precipitate, $x$-ray analysis was performed on the black precipitate. The radiation used was the $\mathrm{K}_{\mathrm{a}}$ of chromium with a vanadium oxide filter. The chromium $\mathrm{x}$-ray tube was contaminated with small amounts of iron. Table II gives the results of the $x$-ray analys is.

Table II

$X$-ray Pattern of Cobalt Precipitate

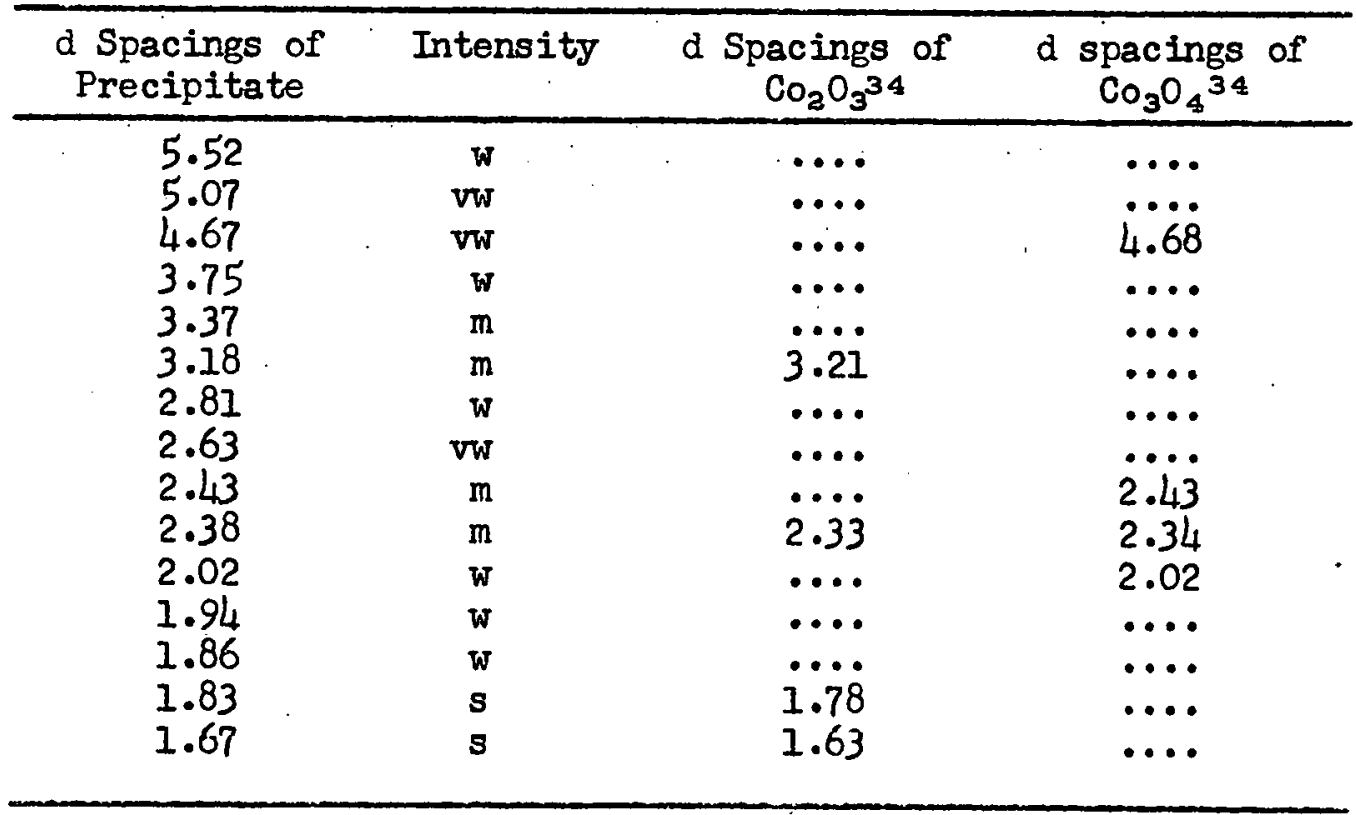


'ine extra lines reported are due to the iron radiation arising from the contamination. The relative intensities of the lines indicate a preponderance of $\mathrm{CO}_{2} \mathrm{O}_{3}$ with small amounts of $\mathrm{Co}_{3} \mathrm{O}_{4}$. It was found that drying the melts at $110^{\circ} \mathrm{C}$ and fusing slowly under vacuum slowed the precipitation process considerably.

The master mixtures of cobalt nitrate and potassium chloride in the $\mathrm{IiNO}_{3}-\mathrm{KNO}_{3}$ eutectic were analyzed for content and homogeneity. Cobalt was determined by electrolys is and found to be constant, in three samples taken, at $7.42 \mathrm{mg}$. of cobalt per gram of eutectic. The chloricle mixture was analyzed by argentometric methods and found to contain $3.96 \mathrm{mg}$. of chloride ion per gram of eutectic.

- The method of continuous variation was utilized by holding the summation of the cobalt ion and chloride ion concentrations constant at $1.94 \times 10^{-2}$ moles per liter while varying the ratio of the cobalt ion to the chloride ion. Measurements were taken for cobalt to chloride ratios of $1: 0,4: 1,3: 2,1: 1,2: 3,1: 4$ and $0: 1$. The temperature of the solutions was held constant at $160^{\circ} \mathrm{C}$ and the density of the eutectic at this temperature was taken as 1.942 , $^{35}$ for calculations of concentrations. Figure 10 shows the spectra obtained for the mixtures of cobalt and chloride ions in the eutectic, two millimeter cells being used. The absorbance of the solutions minus the absorbance of a solution with no reaction, $A_{0}-A_{\text {, was }}$ plotted against mole fraction of chloride, the mole fraction of chloride being the number of moles of chloride ion divided by the sum of the moles of chloride ion and cobalt ion. Figure 11 gives the results of such a plot. 


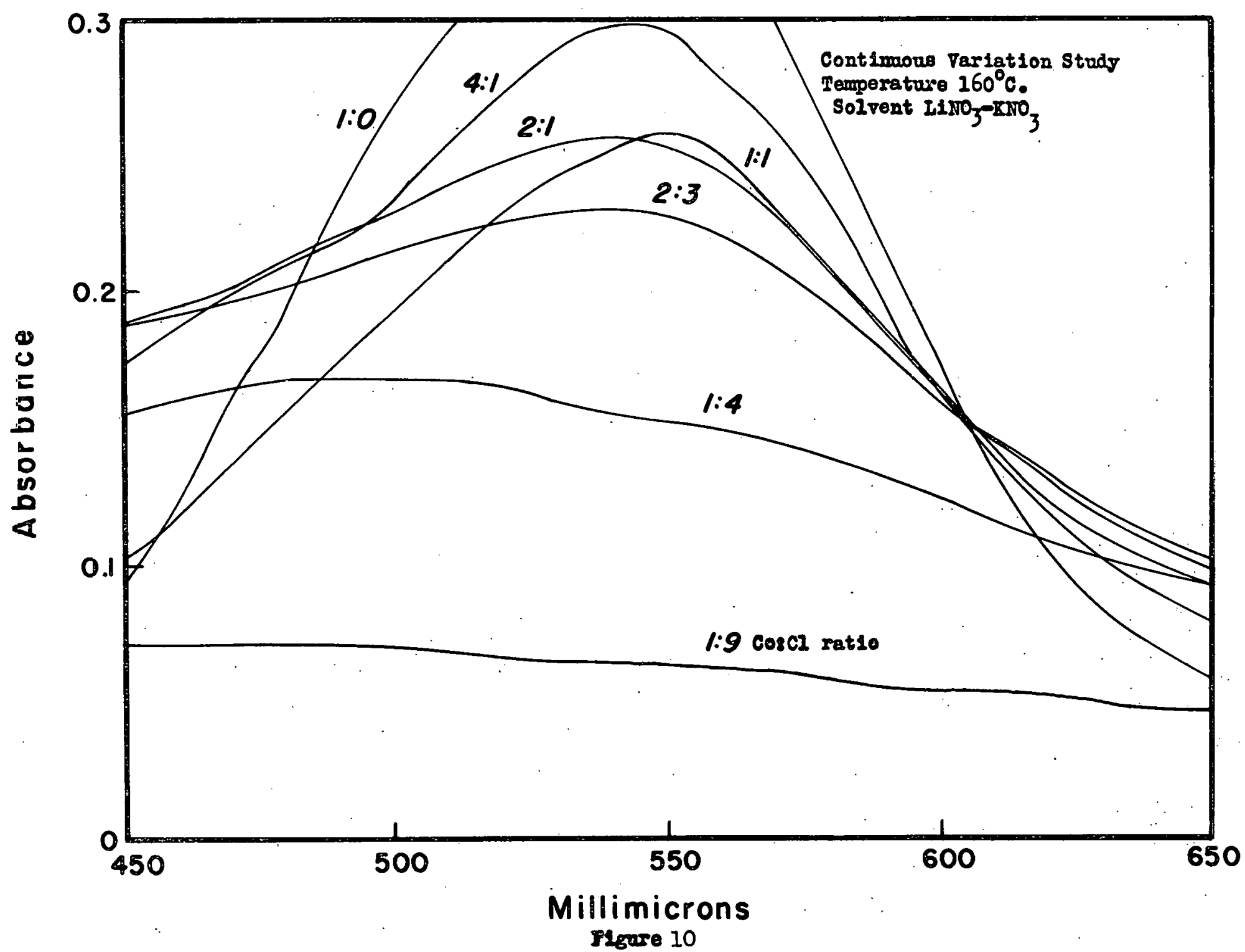

Spectra of Cobalt-Chloride Mixtures 


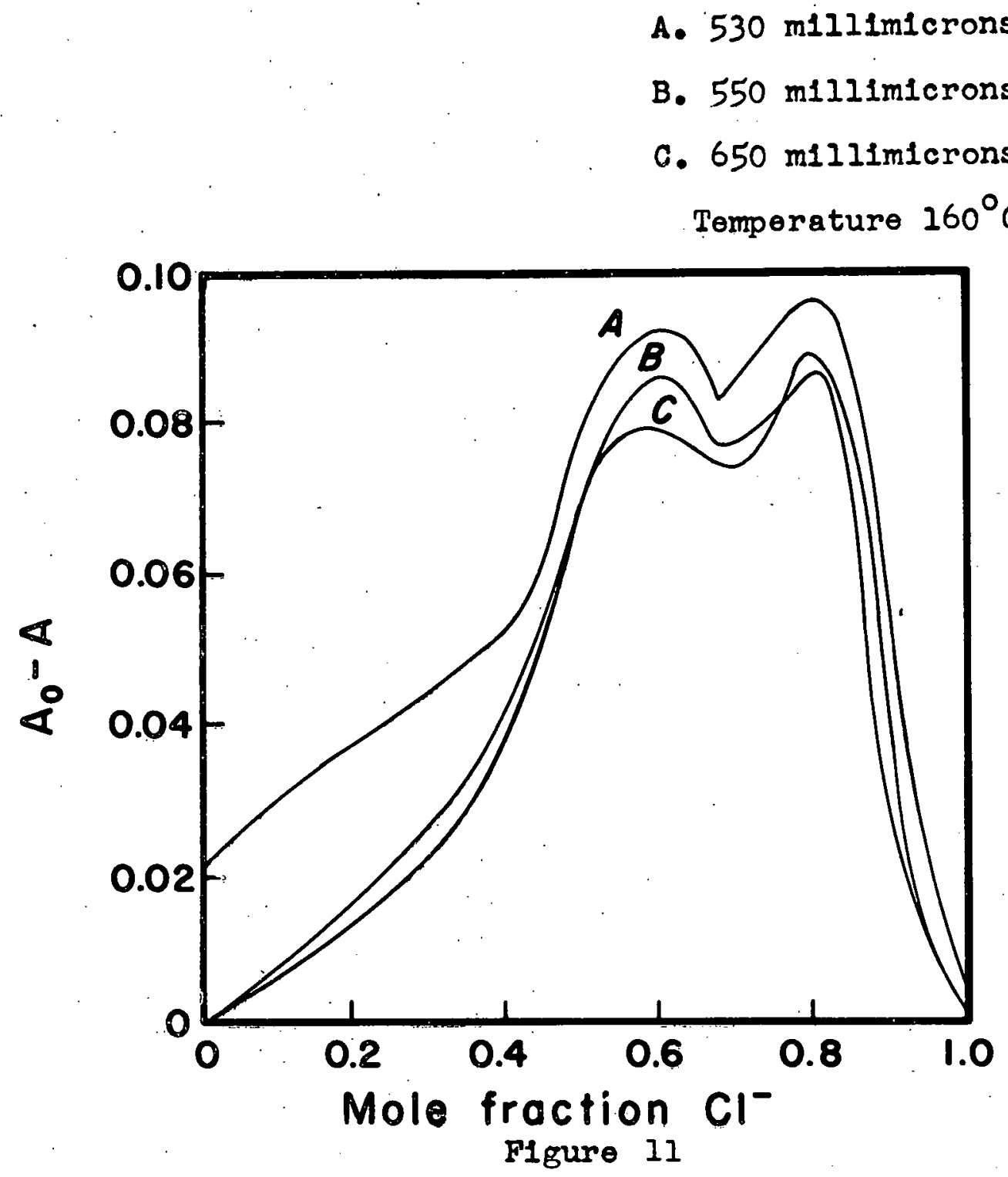

Continuous Varlation Study, Co-CI System 
The McConnell-Davidson technique was utilized in an attempt to evaluate the formation constant of the first cobaltchloro complex, $\mathrm{CoCl}^{+}$. In this experiment, the chloride ion concentration was held constant at $3.9 \times 10^{-3}$ moles per liter while the cobalt ion concentration was varied from $9.7 \times 10^{-3}$ to $1.94 \times 10^{-2}$ moles per liter. Figure 12 shows spectra obtained by this procedure. The temperature was $160^{\circ} \mathrm{C}$ and the density was taken as previously stated. The spectrum of cobalt with no added chloride is also included. In this technique the evaluation of the formation constant of the first cobalt-chloro complex is performed by a graphical method. A plot of $\mathrm{C}_{\mathrm{Co}_{0}} \times \mathrm{C}_{\mathrm{Cl}} /\left(\mathrm{A}_{\mathrm{O}}-\mathrm{A}\right)$ versus $\mathrm{C}_{\mathrm{Co}_{\mathrm{O}}}$ is shown in $\mathrm{Fig} .13$. The ratio of the slope of the straight line to the intercept of the straight line is equal to $k_{2}$. Various straight lines drawn through the point obtained give a range of $k_{1}$ from 40 to over 300 .

(b) Spectral Studies of Cobalt-Bromo Complexes.- The spectra of cobalt nitrate in $\mathrm{LiNO}_{3}-\mathrm{KNO}_{3}$ eutectic with added bromide ion are show in Fig. 14. As the spectral shifts were no more pronounced than with added chloride ion, no further studies were carried out.

2. Spectral Studies of Chromium Salts in Various Nitrate Melts.- (a) $\mathrm{IiNO}_{3}-\mathrm{KNO}_{3}$ Eutectic.- The spectra of $\mathrm{CrCl}_{3}, \mathrm{~K}_{2} \mathrm{CrO}_{4}$ were obtained in the $\mathrm{IiNO}_{3}-\mathrm{KNO}_{3}$ eutectic, at $160^{\circ} \mathrm{C}$, by adding small weighed amounts of each salt to a known amount of eutectic. In all cases, a blank of the eutectic was used. The spectrum of the nitrate molt itself was obtained using an empty 2-mm. cell as a reference, 


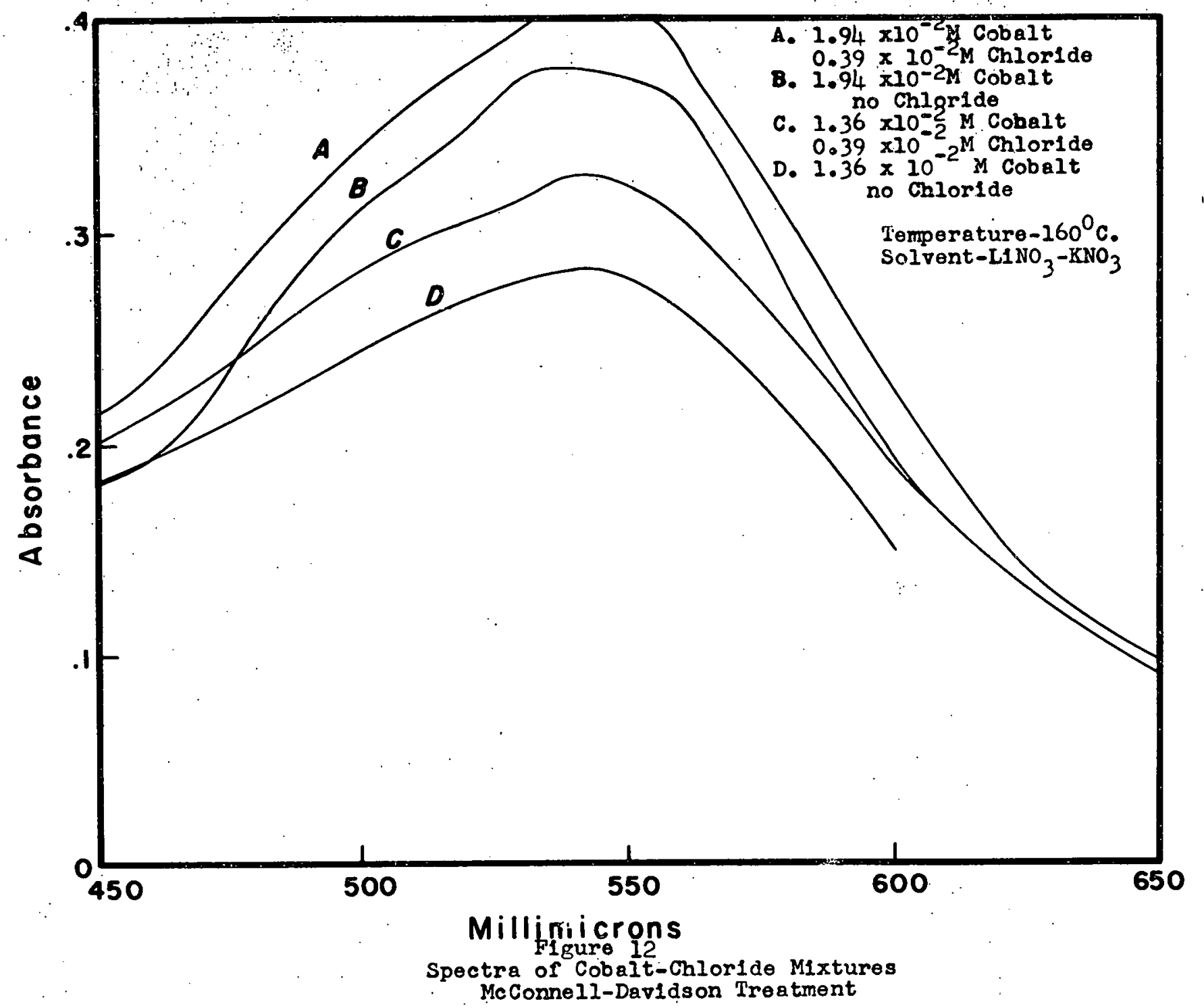

$30 \% \quad 05 \%$ 


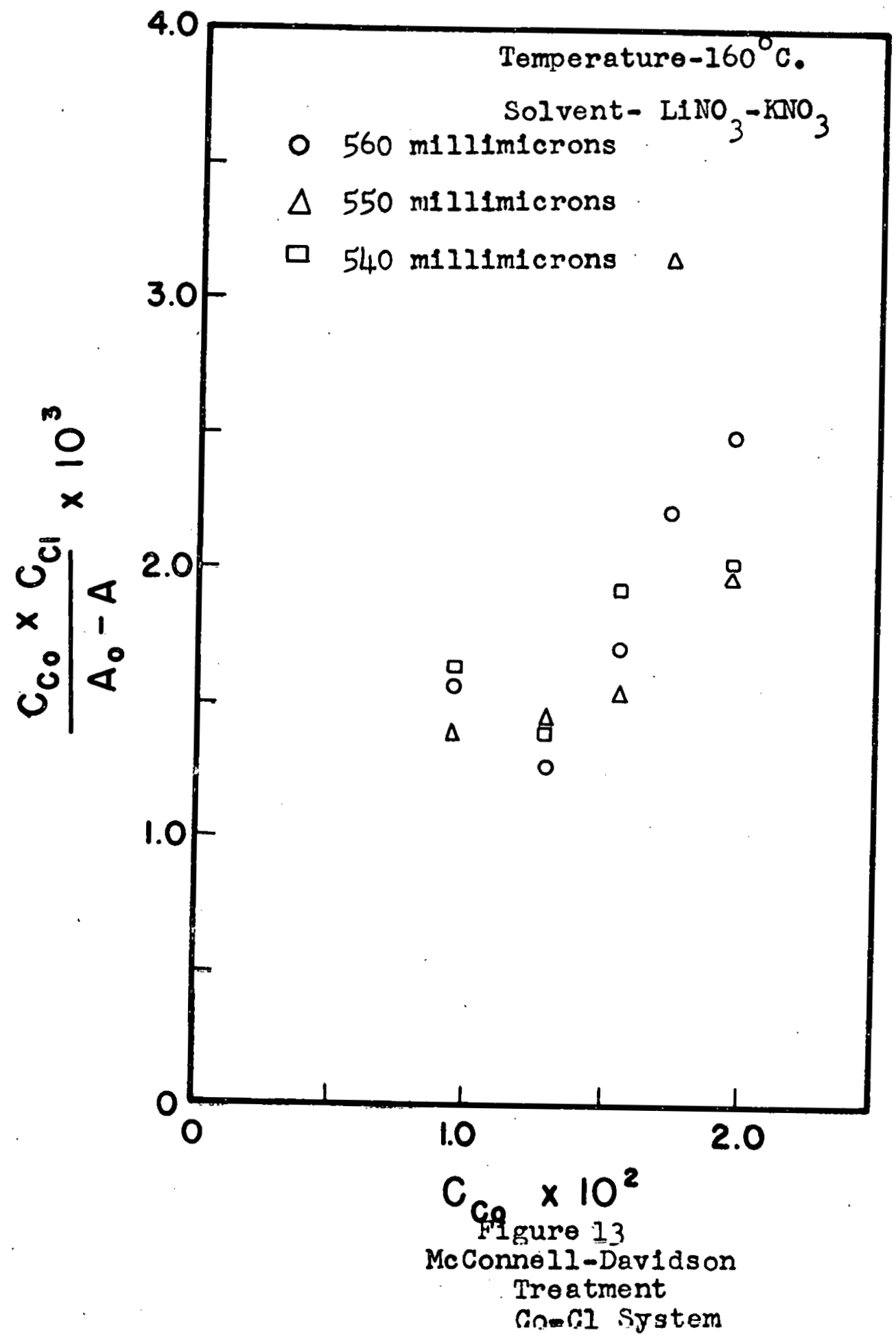




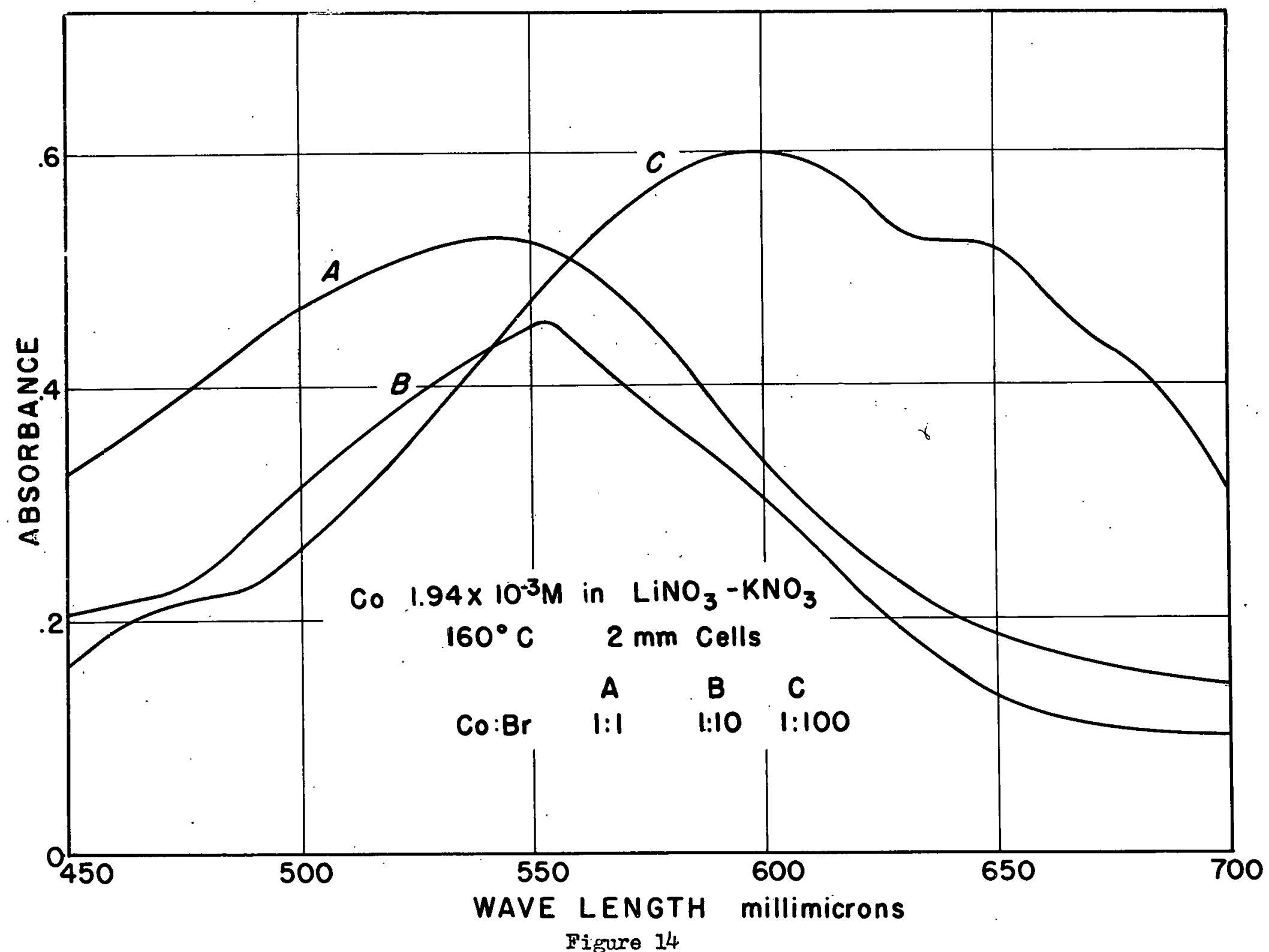

Spectra of Cobailt-Bromide Mixtures 
Fig. 15. Figure 16 shows the spectra obtained from the various chromium salts in the $\mathrm{LiNO}_{3}-\mathrm{KNO}_{3}$ eutectic. It was noted that addition of $\mathrm{CrCl}_{3}$ to the melt resulted in an initial green color which rapidly changed to yellow with evolution of oxides of nitrogen. The addition of excess chloride to the nitrate melt in an attempt to stabilize the $\operatorname{Cr}($ III) species proved unsuccessful.

The spectrum of $\mathrm{K}_{2} \mathrm{CrO}_{4}$ in basic aqueous solution was taken as a means of comparison to the spectra obtained for the chromium salts in the nitrate eutectic. Figure 17 shows the spectrum of $\mathrm{K}_{2} \mathrm{CrO}_{4}$ in aqueous solution, $\mathrm{pH} 10.0$, in a $1 \mathrm{~cm}$. cell. The solution had a distinct yellow color. It was noted that in the fused nitrate eutectic, large amounts of $\mathrm{K}_{2} \mathrm{Cr}_{2} \mathrm{O}_{7}$ retained the characteristic orange color of acidic aqueous solutions of dichromate. Accordingly, an attempt to obtain the spectra of the dichromate ion in the nitrate. melt by a differential technique was made. Two melts containing comparitively large amounts of $\mathrm{K}_{2} \mathrm{Cr}_{2} \mathrm{O}_{7}$ were used to obtain the differen-tial spectrum. The more dilute solution $\left(30 \mathrm{mg} \cdot\right.$ of $\mathrm{K}_{2} \mathrm{Cr}_{2} \mathrm{O}_{7}$ in $20 \mathrm{~g}$. eutectic) was placed in the reference compartment. The more concentrated solution ( $40 \mathrm{mg}$. of $\mathrm{K}_{2} \mathrm{Cr}_{2} \mathrm{O}_{7}$ in $20 \mathrm{~g}$. eutectic) was placed in the sample compartment. The resulting spectrum obtained at $160^{\circ} \mathrm{C}$ is shown in Fig. 18 . 


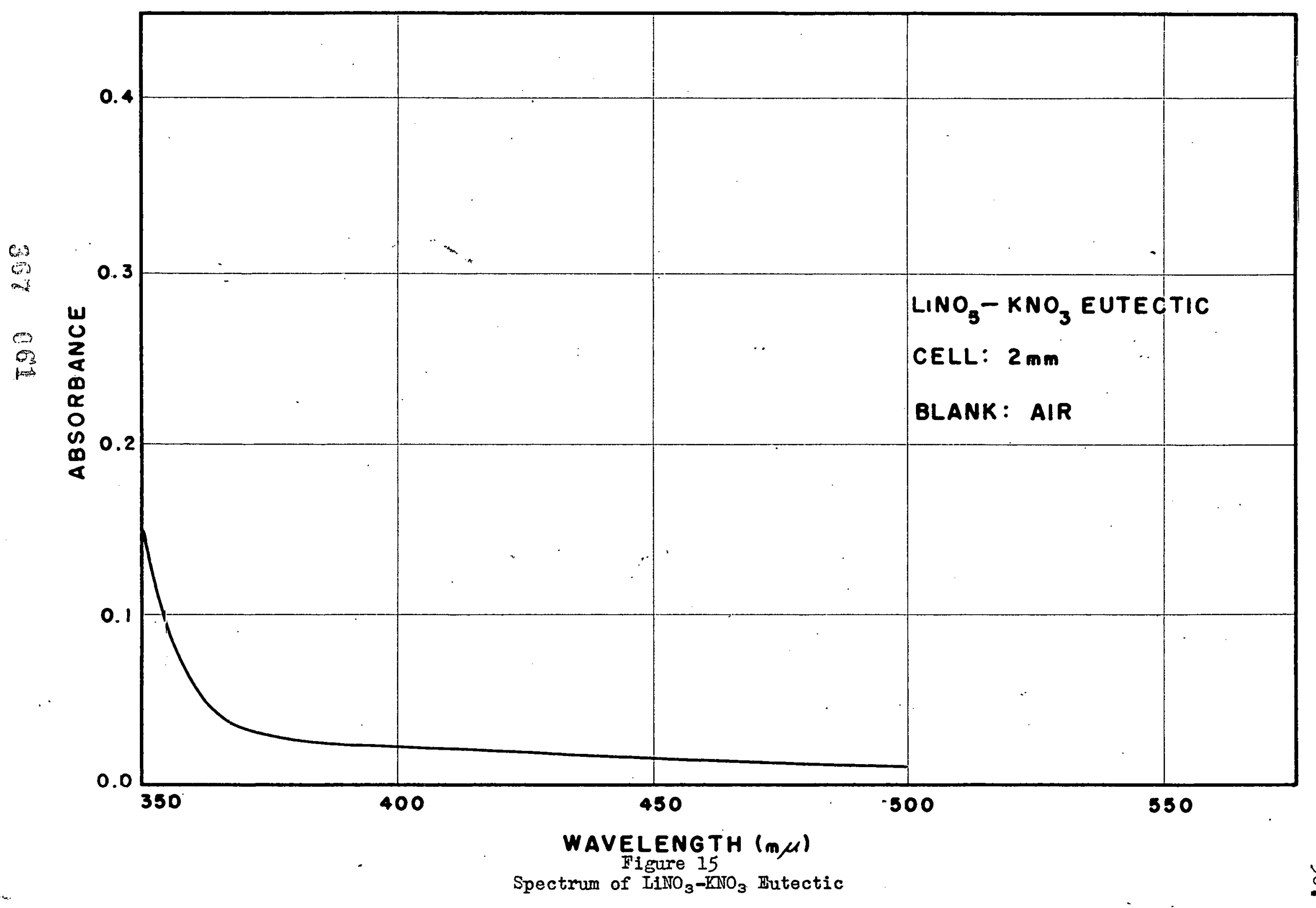




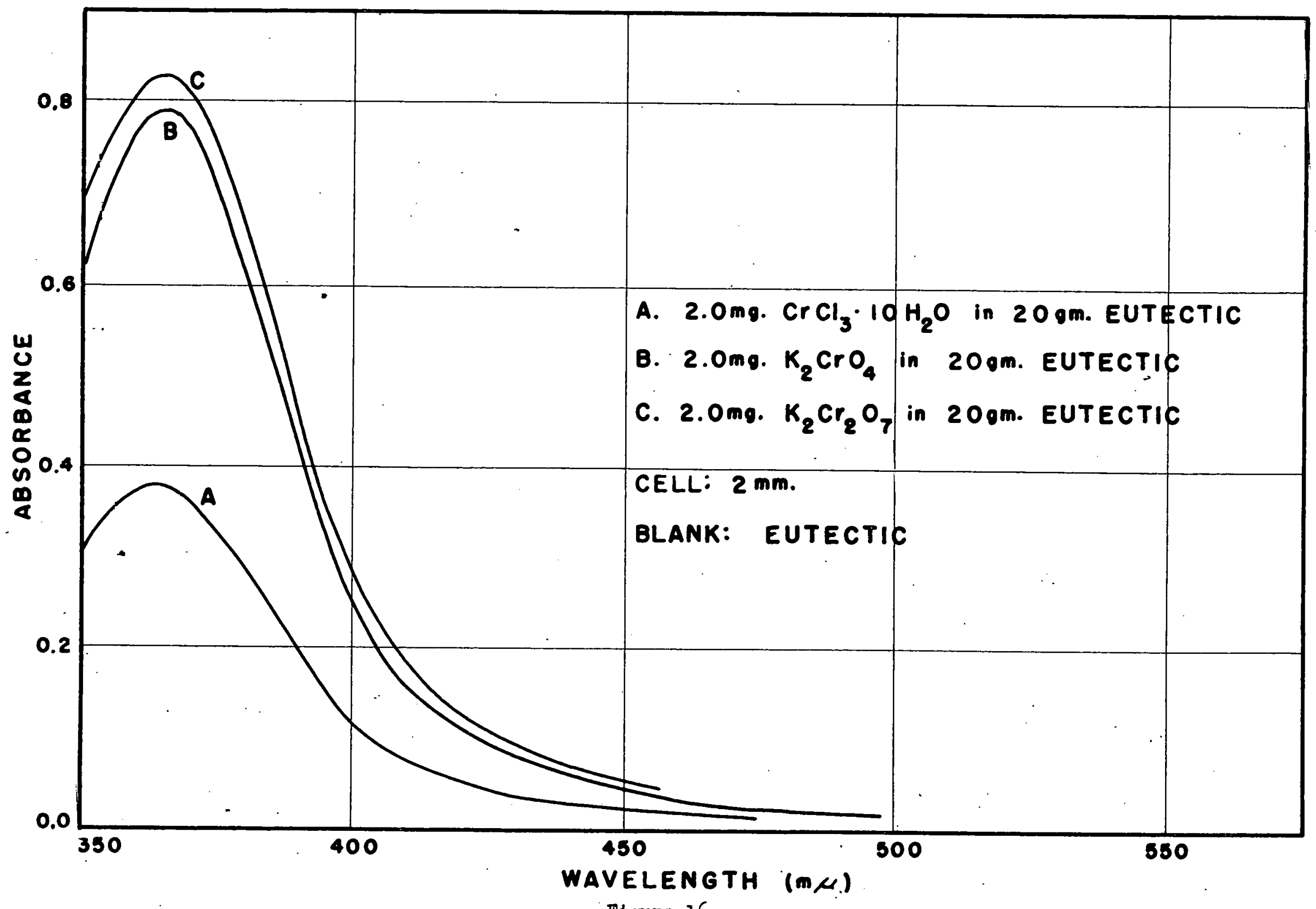

F'igure 16

Spectra of Chromium Salts in LiNO $3-\mathrm{KNO}_{3}$ 


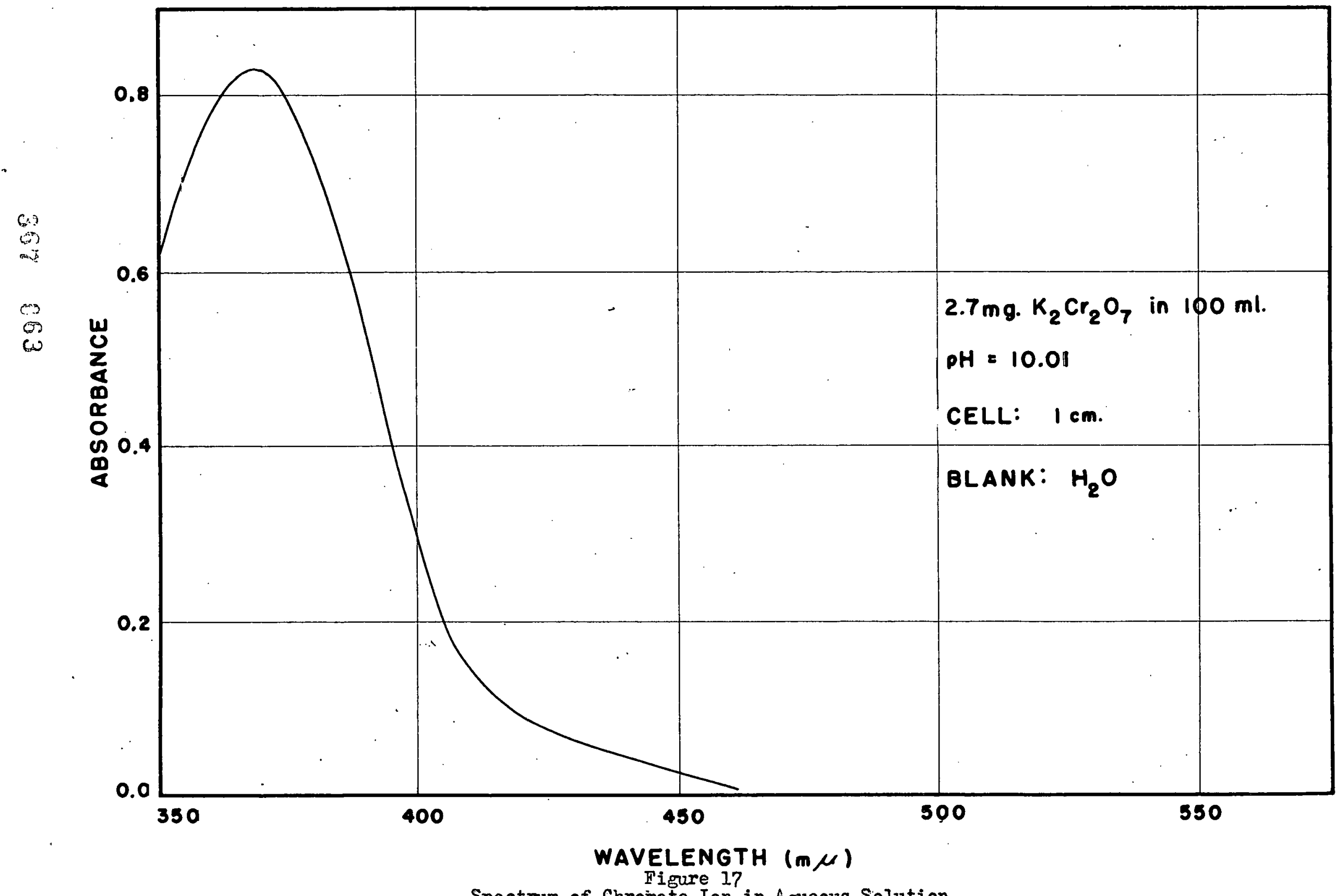

Spectrum of Chromate Ion in Aqueous Solution 


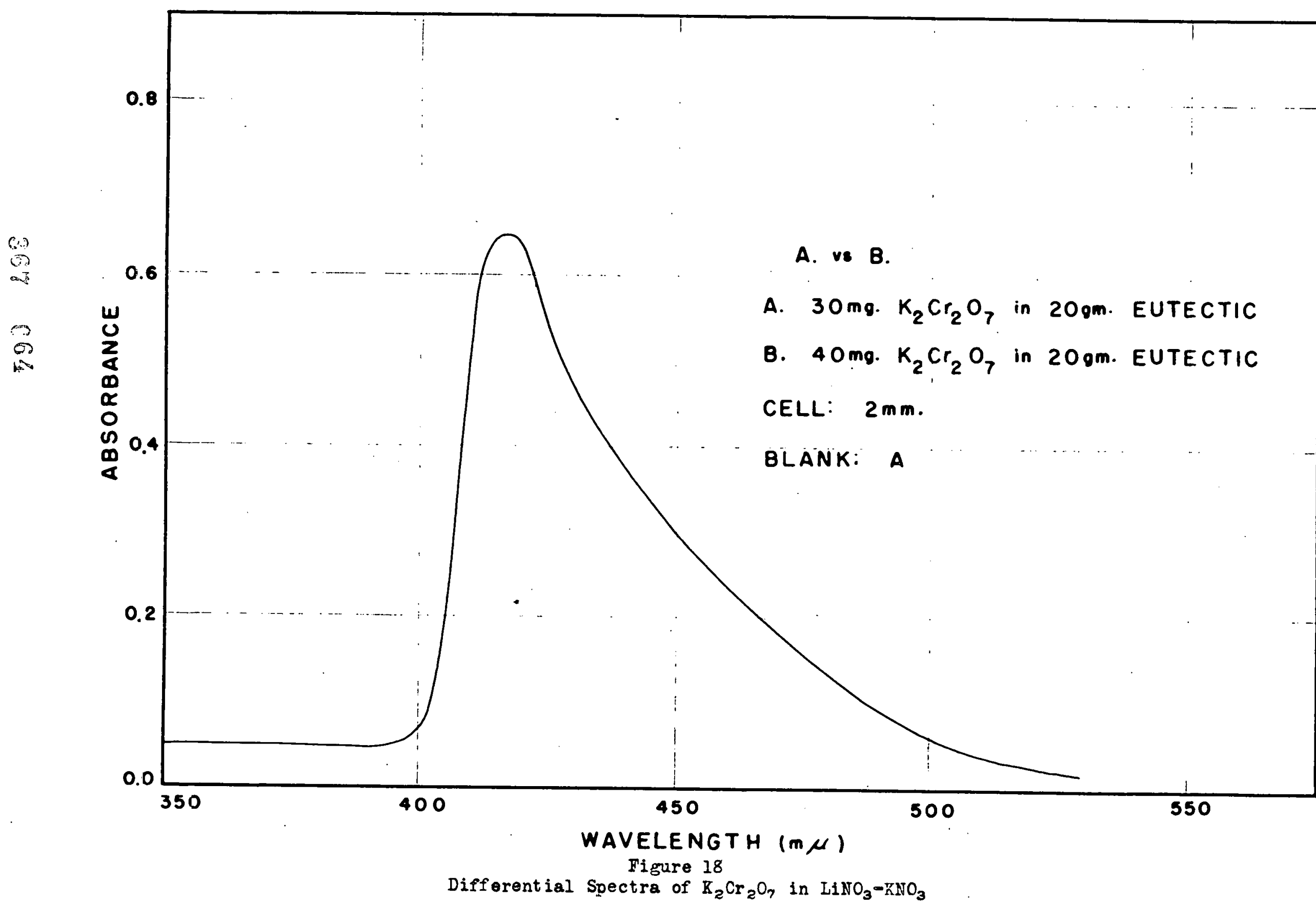

Differential spectra of $\mathrm{K}_{2} \mathrm{Cr}_{2} \mathrm{O}_{7}$ in $\mathrm{LiNO}_{3}-\mathrm{KNO}_{3}$

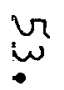


It was noted that the addition of aluminum nitrate to the nitrate melt containing potassium chromate resulted in a color change of yellow to orange. Addition of sodium carbonate to a dichromate melt resulted in a color change of orange to yellow and evolution of carbon dioxide.

(b) Silver Nitrate.- Silver nitrate was used as a solvent for the various chromiun salts being investigated. The spectrum of silver nitrate itself was taken, Fig. 19 showing that obtained at $250^{\circ} \mathrm{C}$. The spectra obtained for solutions of $\mathrm{CrCl}_{3}, \mathrm{~K}_{2} \mathrm{Cr}_{3} \mathrm{O}_{7}$ and $\mathrm{K}_{2} \mathrm{CrO}_{4}$ in silver nitrate are shown in Fig. 20, with silver nitrate used as a blank. The addition of $\mathrm{CrCl}_{3}$ to the molten silver nitrate resulted in evolution of oxides of nitrogen.

A Beer's Law plot of concentration of $\mathrm{K}_{2} \mathrm{Cr}_{2} \mathrm{O}_{7}$ versus absorbance, in silver nitrate, is given in Fig. 21. The temperature was $300^{\circ} \mathrm{C}$. The molar extinction coefficients at various wavelengths were calculated and plotted in Fig. 22.

(c) $\mathrm{KNO}_{3}-\mathrm{NaNO}_{3}$ Eutectic.- The spectrum of $\mathrm{KNO}_{3}-\mathrm{NaNO}_{3}$ eutectic was taken using an empty cell as a blank and was found to be similar to that found for the $\mathrm{LiNO}_{3}-\mathrm{KNO}_{3}$ eutectic. Figure 23 shows the spectra obtained of solutions of $\mathrm{CrCl}_{3}, \mathrm{~K}_{2} \mathrm{CrO}_{4}$ and $\mathrm{K}_{2} \mathrm{Cr}_{2} \mathrm{O}_{7}$ in this eutectic at $300^{\circ} \mathrm{C}$. The addition of $\mathrm{CrCl}_{3}$ to this nitrate melt age in resulted in the evolution of nitrogen oxidcs. To obtain the epectra of the diohromate species in this melt, vartous procedures were attempted. 


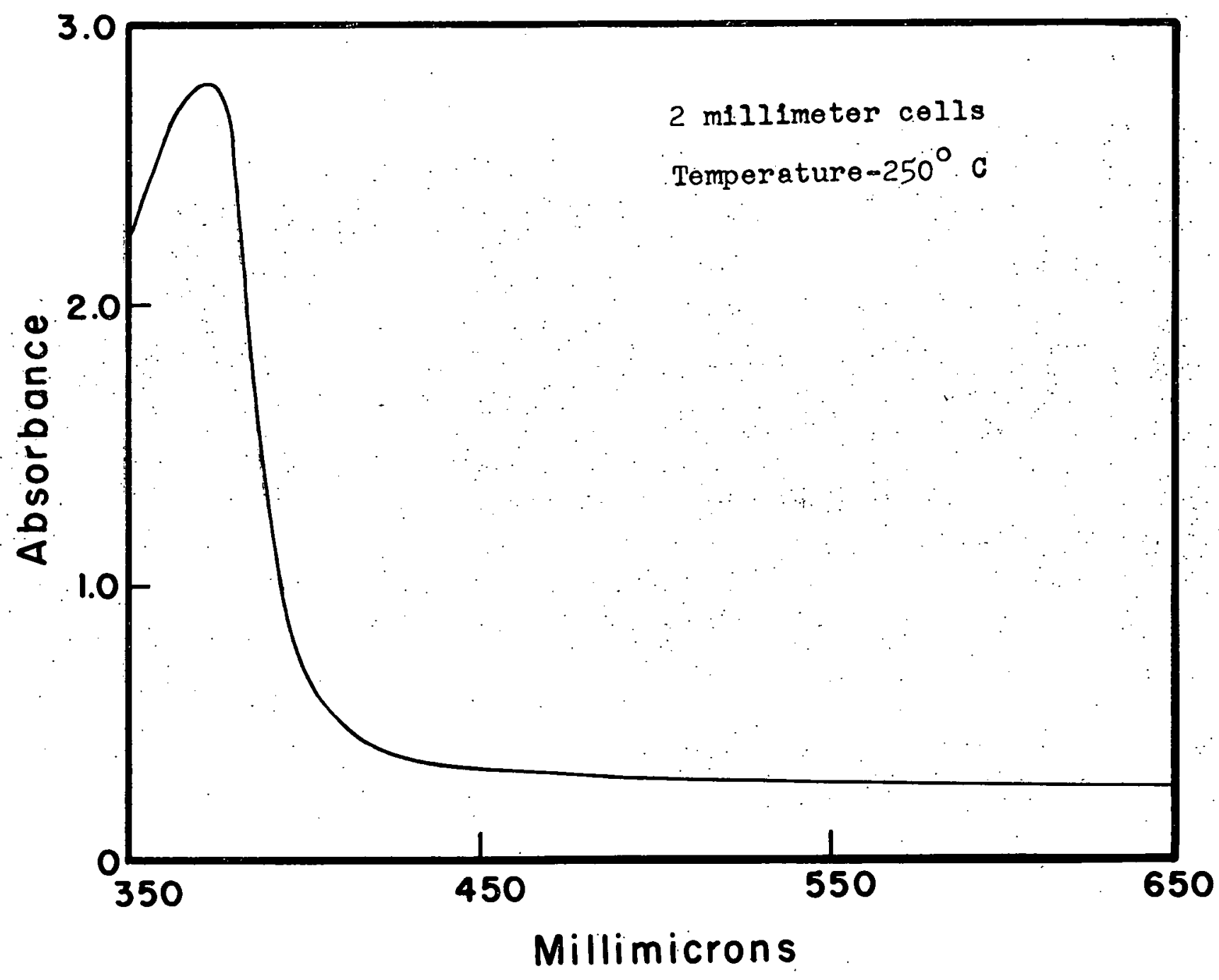

Figure 19

Spectra of Silver Nitrate 
A. 0.6 milligrams $\mathrm{K}_{2} \mathrm{Cr}_{2} \mathrm{O}_{7}$ in 20 grams

B. 0.6 m1lilgrams $\mathrm{K}_{2} \mathrm{CrO}_{4}$ in 20 grams

c. 0.6 milligrams $\mathrm{CrCl}_{3}$ in 20 grams 2 millimeter cells, $\mathrm{AgNO}_{3}$ as Solvent

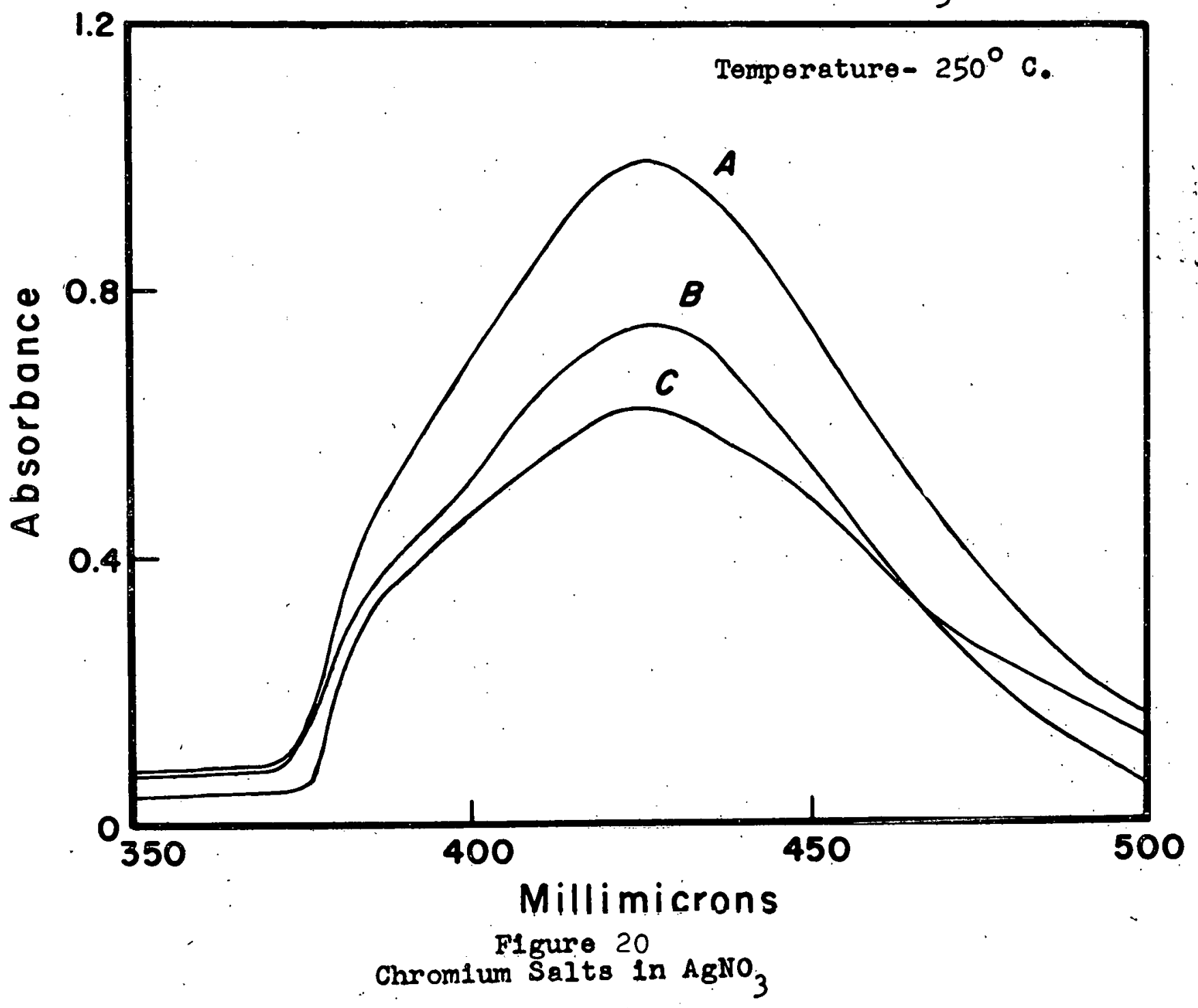




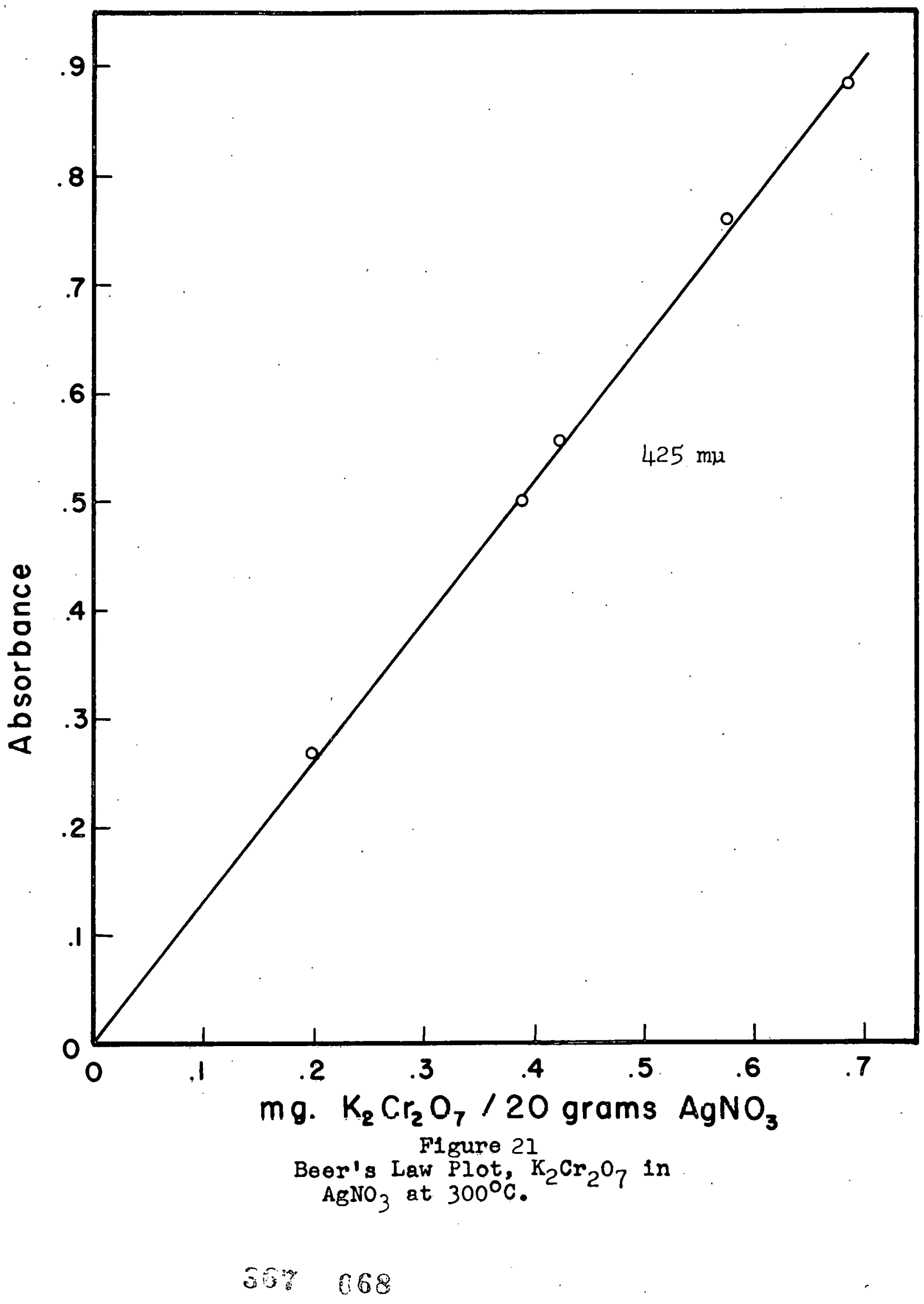




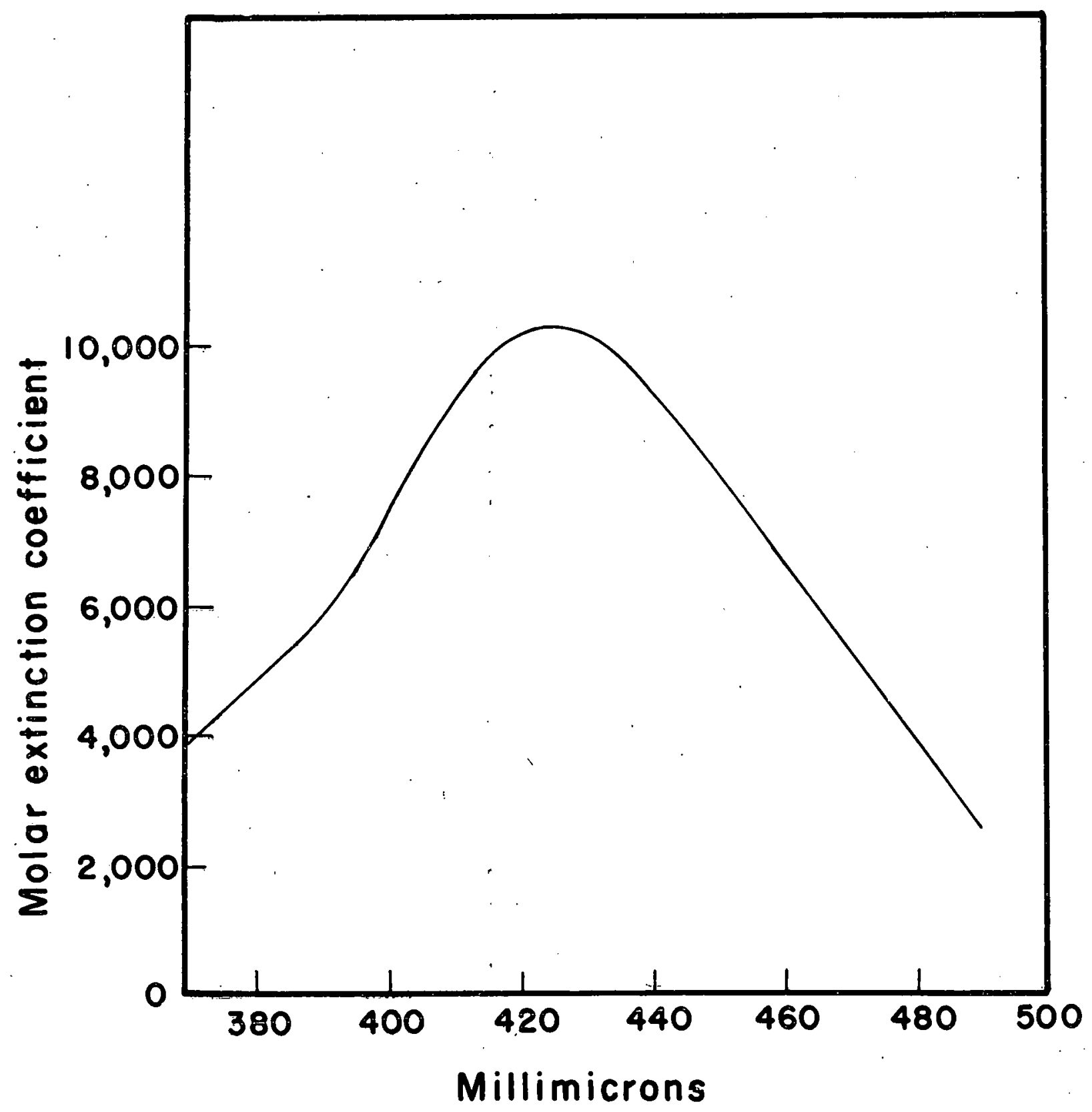

Figure 22

Molar Extinction Coefficients

$\mathrm{K}_{2} \mathrm{Cr}_{2} \mathrm{O}_{7}$ in $\mathrm{AgNO}_{3}$ at $300^{\circ} \mathrm{C}$. 


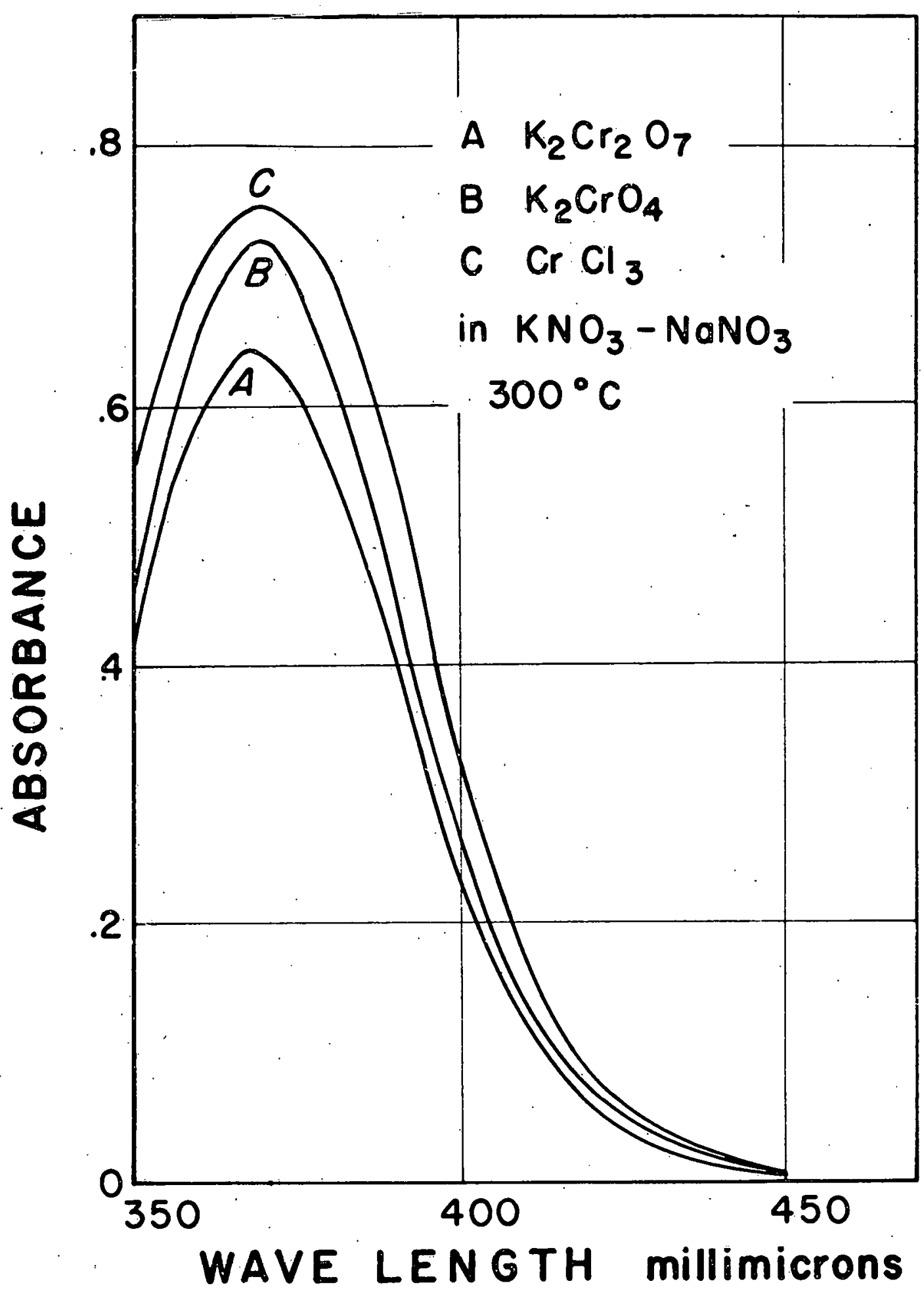

\footnotetext{
Figure 23

Spectra of Chromium Salts in $\mathrm{KNO}_{3}-\mathrm{NaNO}_{3}$
} 
The addition of harium nitrate to this melt to precipitate the chromate form proved fruitless, since the process was a continuous one, and the formation of the barium chromate precipitate interfered with the measurements. The addition of silver nitrate to this melt to acidify it was unsuccessful since a deep red precipitate formed, which, upon redissolving, gave the spectrum associated with the chromate form. Sodium metaphosphate was added to the melt in an attempt to acidify the melt. In large concentrations of chromate ion, addition of metaphosphate ion resulted in a conversion of the color from yellow to orange, subsequent addition of carbonate Ion reconverting the orange color to yellow. Figure 24 is a color picture taken of a similar process starting with dichromate melts. In small concentrations of chromate ion, addition of metaphosphate resulted in a yellow-green precipitate which redissolved to give the yellow color of the chromate ion, oxides of nitrogen being evolved.

Figure 25 gives the Beer's Law plot of concentration of chromate ion versus absorbance of the solution at $300^{\circ} \mathrm{C}$. The molar extinction coefficients were calculated from the spectra obtained, assuming a density of the melt at $300^{\circ} \mathrm{C}$ of $2.00 ;^{36}$ the values obtained are shown in Fig. 26. A series of differential spectra of solutions containing dichromate are shown in Fig. 27 .

3. Spectral Studies of Chromium Salts in IICl-KCl Eutectic.Spectral studies of chromium salts in the LiCl-KCl eutectic at $400^{\circ} \mathrm{C}$ were obtained. The spectra of the chloride melt itself showed no 
61.

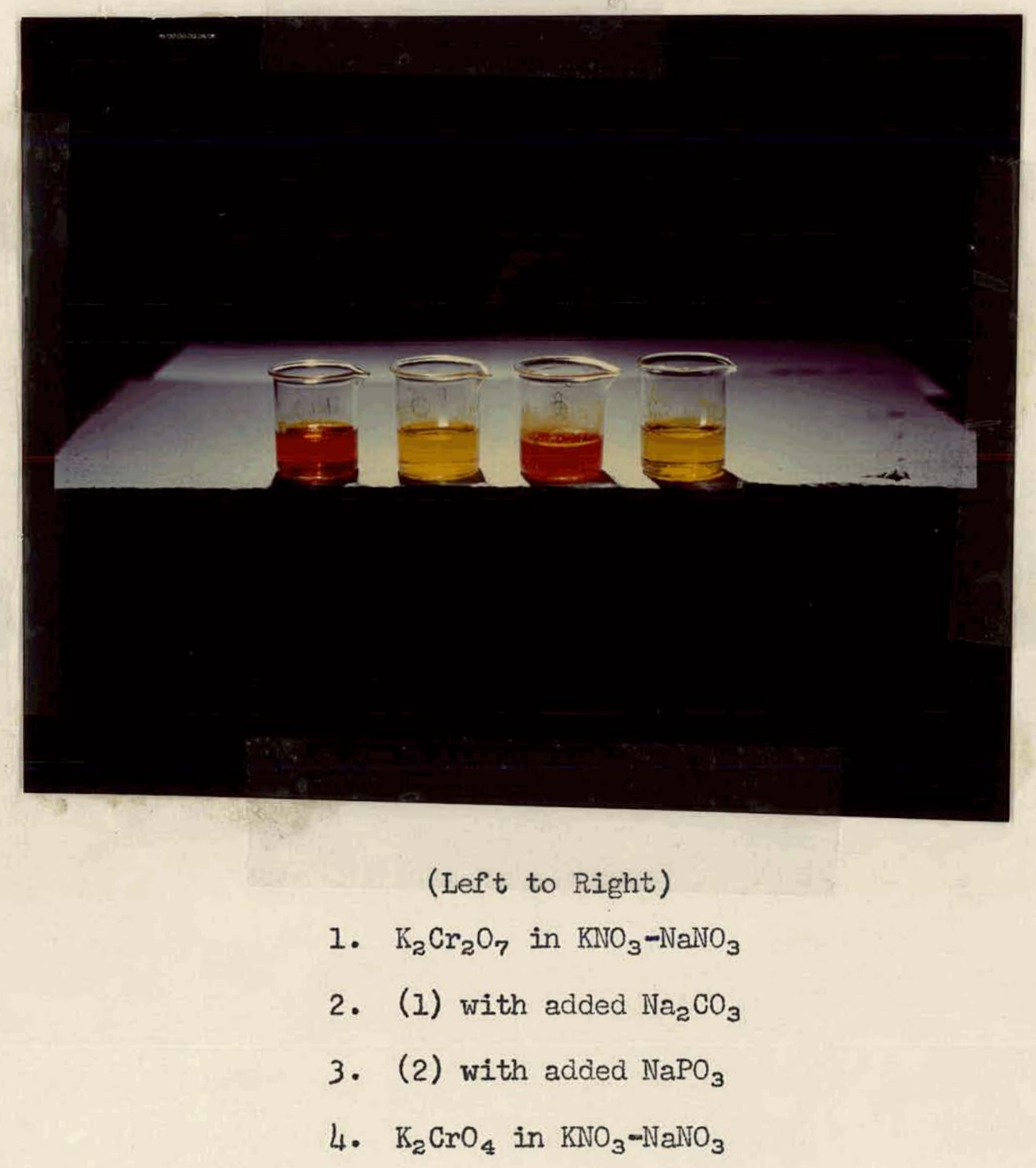

Figure 24

$\mathrm{K}_{2} \mathrm{Cr}_{2} \mathrm{O}_{7}$ and $\mathrm{K}_{2.2} \mathrm{CrO}_{4}$ Solutions in $\mathrm{KNO}_{3}-\mathrm{NaNO}_{3}$ 


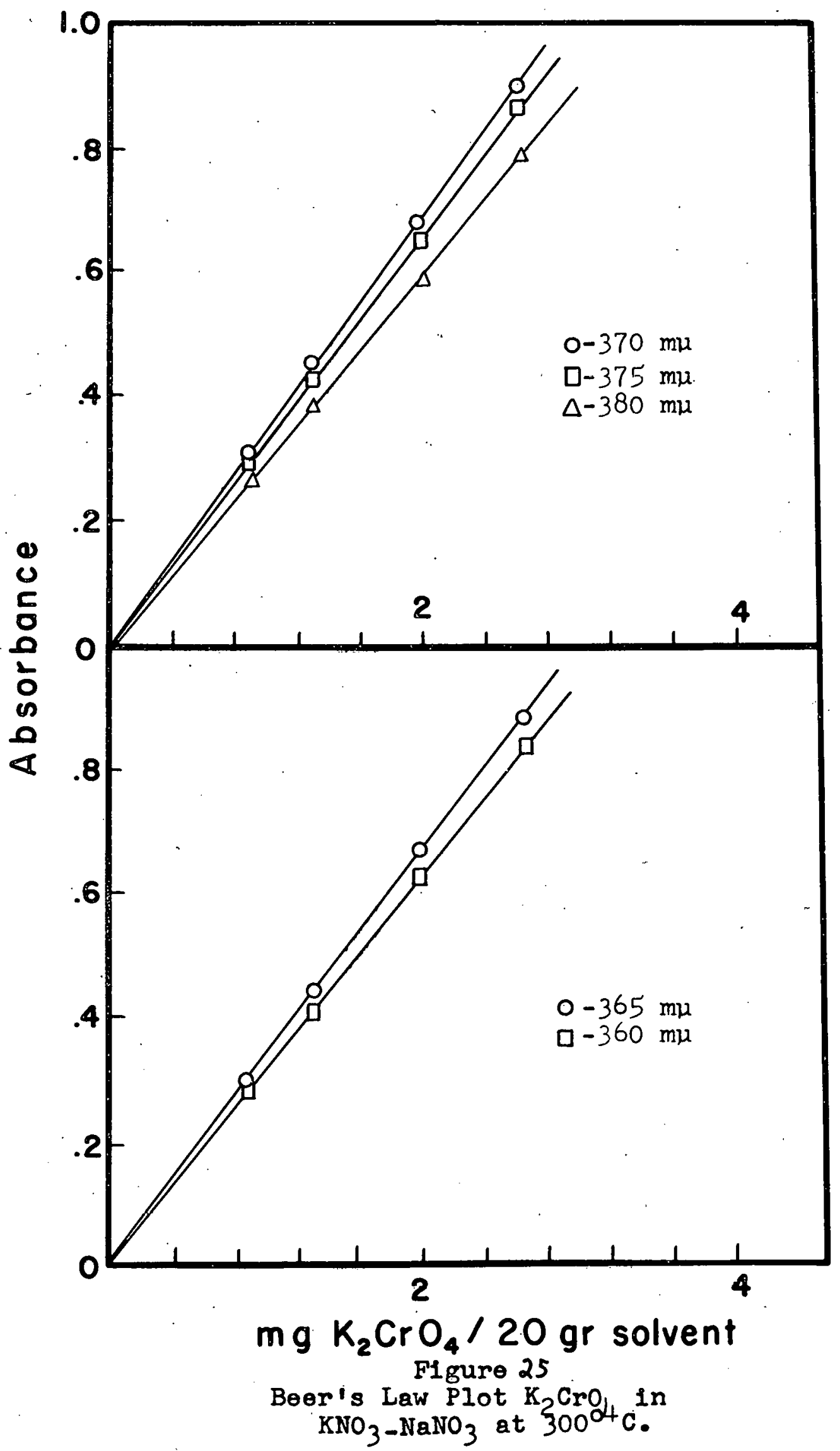




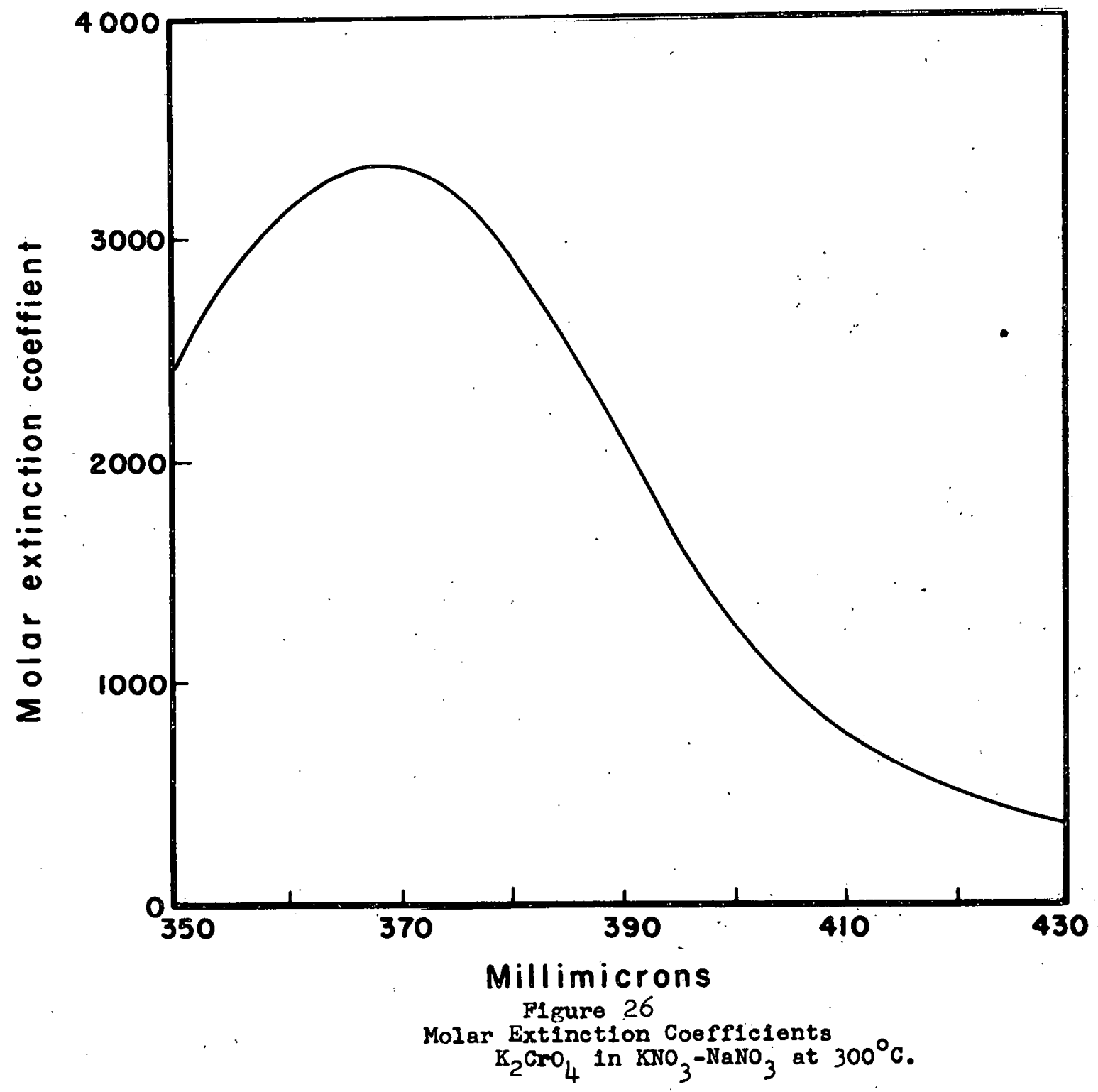

36 ory 


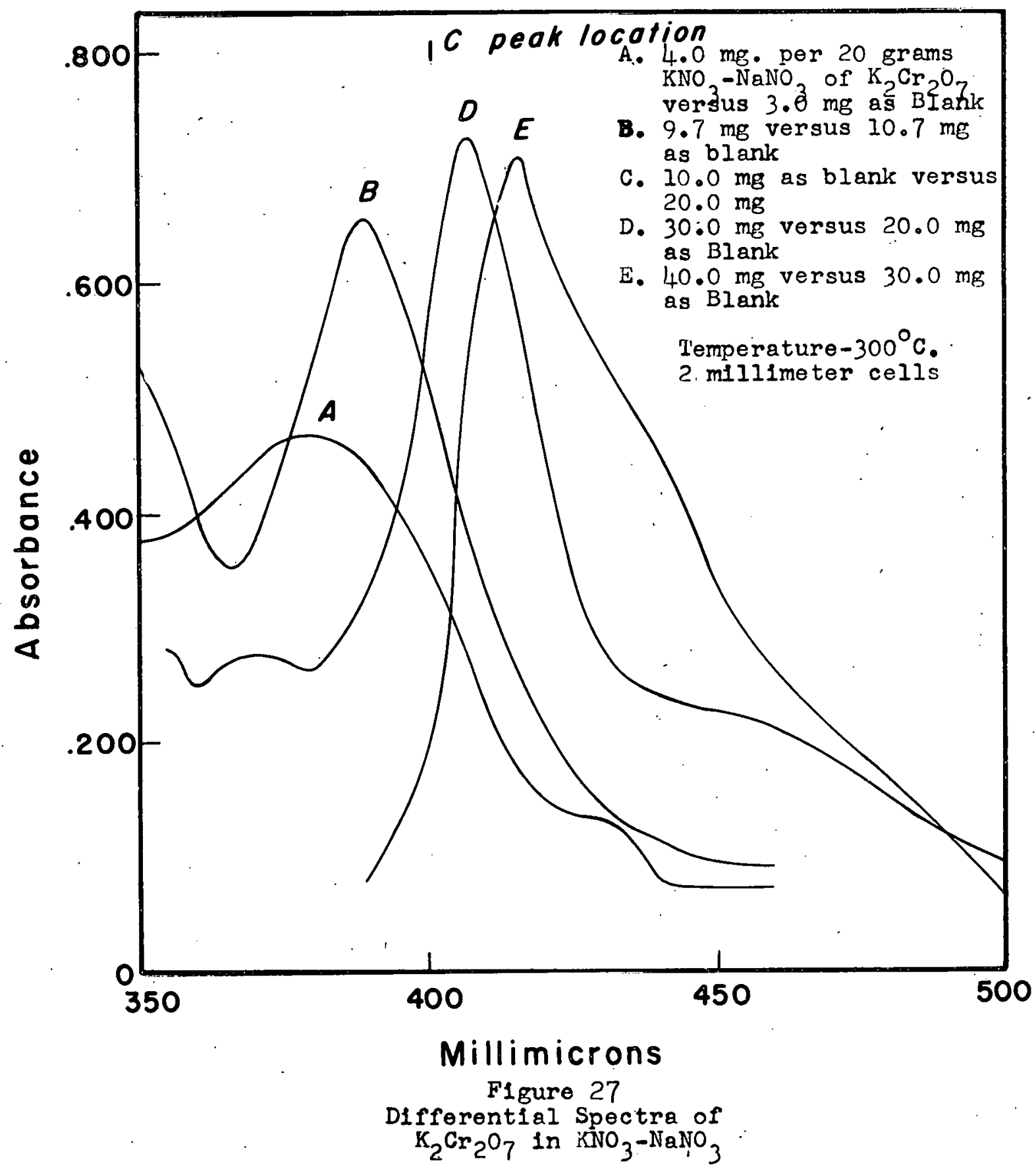


aboorption in the region $350-750 \mathrm{mp}$. The spectra of $\mathrm{K}_{2} \mathrm{Cr}_{2} \mathrm{U}_{7}$ and $\mathrm{K}_{2} \mathrm{CrO}_{4}$ in the chloride eutectic were obtained. Figure 28 shows that the spectra obtained for both species are identical. The spectrum of $\mathrm{CrCl}_{3}$ in the chloride melt was obtained and is shown in $\mathrm{Fig} .29$. The melt containing the chromic chloride resembled the purple color of an aqueous permanganate solution. When $\mathrm{K}_{2} \mathrm{Cr}_{2} \mathrm{O}_{7}$ was dissolved in the chloride melt and dry HCl passed through the melt, chlorine gas was evolved and the melt became distinctly purple in color. The spectrum of this melt ras taken; Fig. 30 shows that this spectrum is identical with that of $\mathrm{CrCl}_{3}, \mathrm{Fig} .29$.

Attempts to acidify the chloride melt containing dichromate ion by addition of sodium metaphosphate resulted in spectra exhibiting absorption edges at approximately $355 \mathrm{m \mu}$. No structure was found in the spectra that could be attributed to either dichromate or chromate ion.

4. Spectrophotometric Determination of Formation Constants of Lead-Chloro and Lead-Bromo Complexes in $\mathrm{KNO}_{3}-\mathrm{NaNO}_{3}$ Eutectic.-

(a) Lead=ChIoro Complexes.- In Section II,F, the use of determinations of the increase in solubility of sparingly soluble salts, with increasing halide ion concentration, as a means of evaluating formation constants of complex ions is discussed. The increase in the solubility of lead chromate as a function of added chloride ion, with excess lead ion present, was followed spectrophotometrically. The concentrations of chromate lon in the fused nitrate melt were 


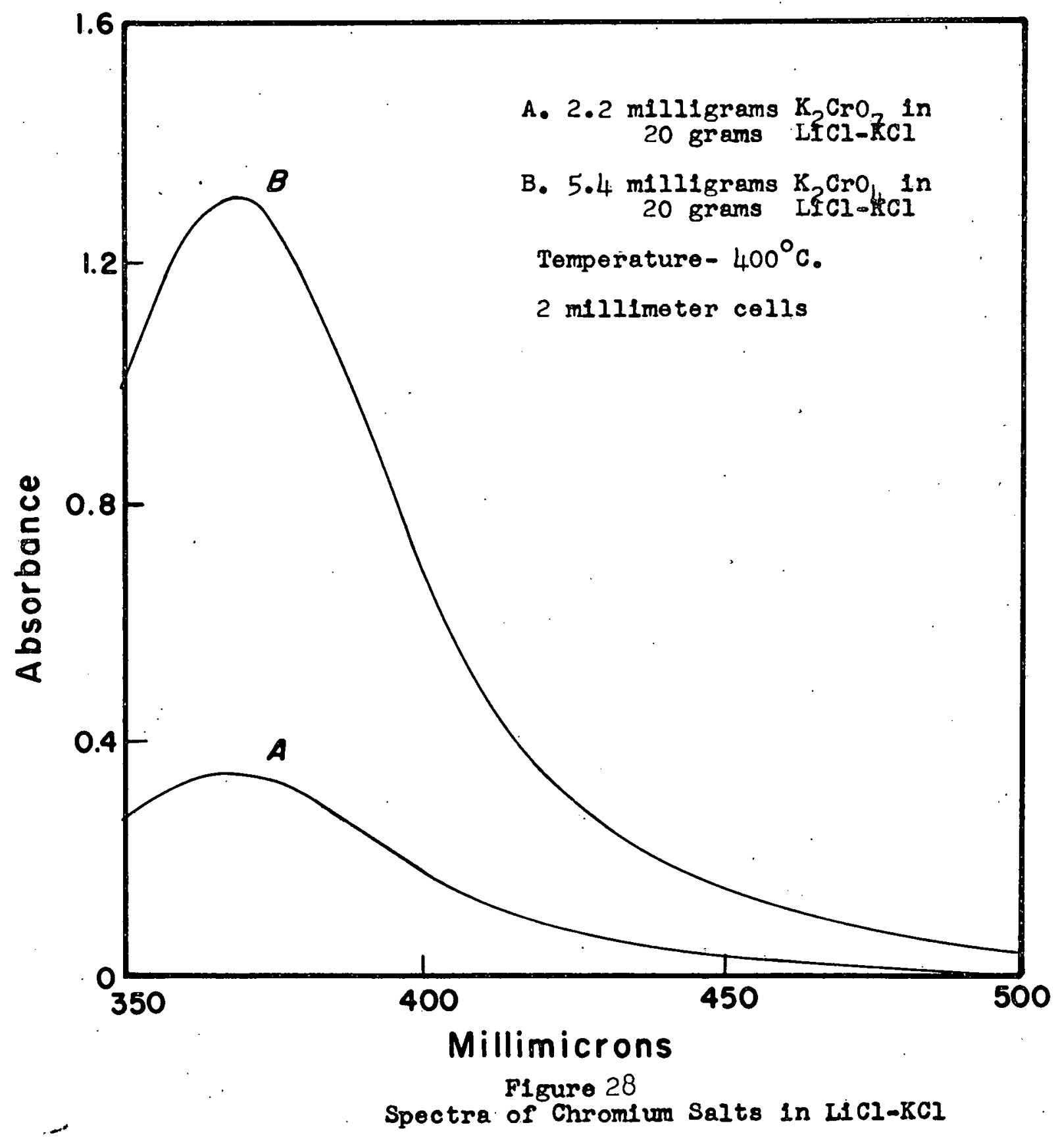




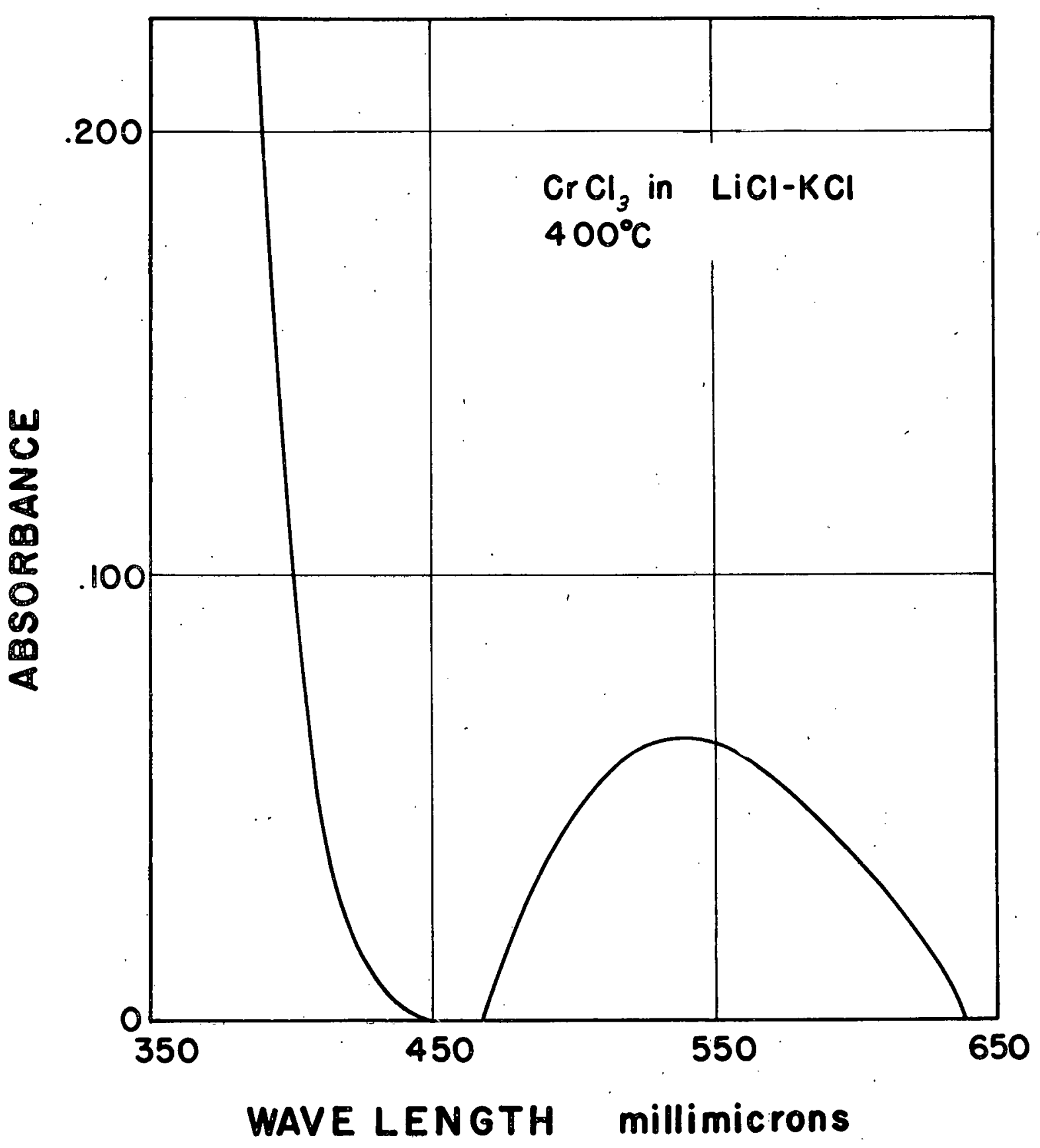

Figure 29

Spectrum of $\mathrm{OrOl}_{3}$ in $\mathrm{LICl-KOI}$ 


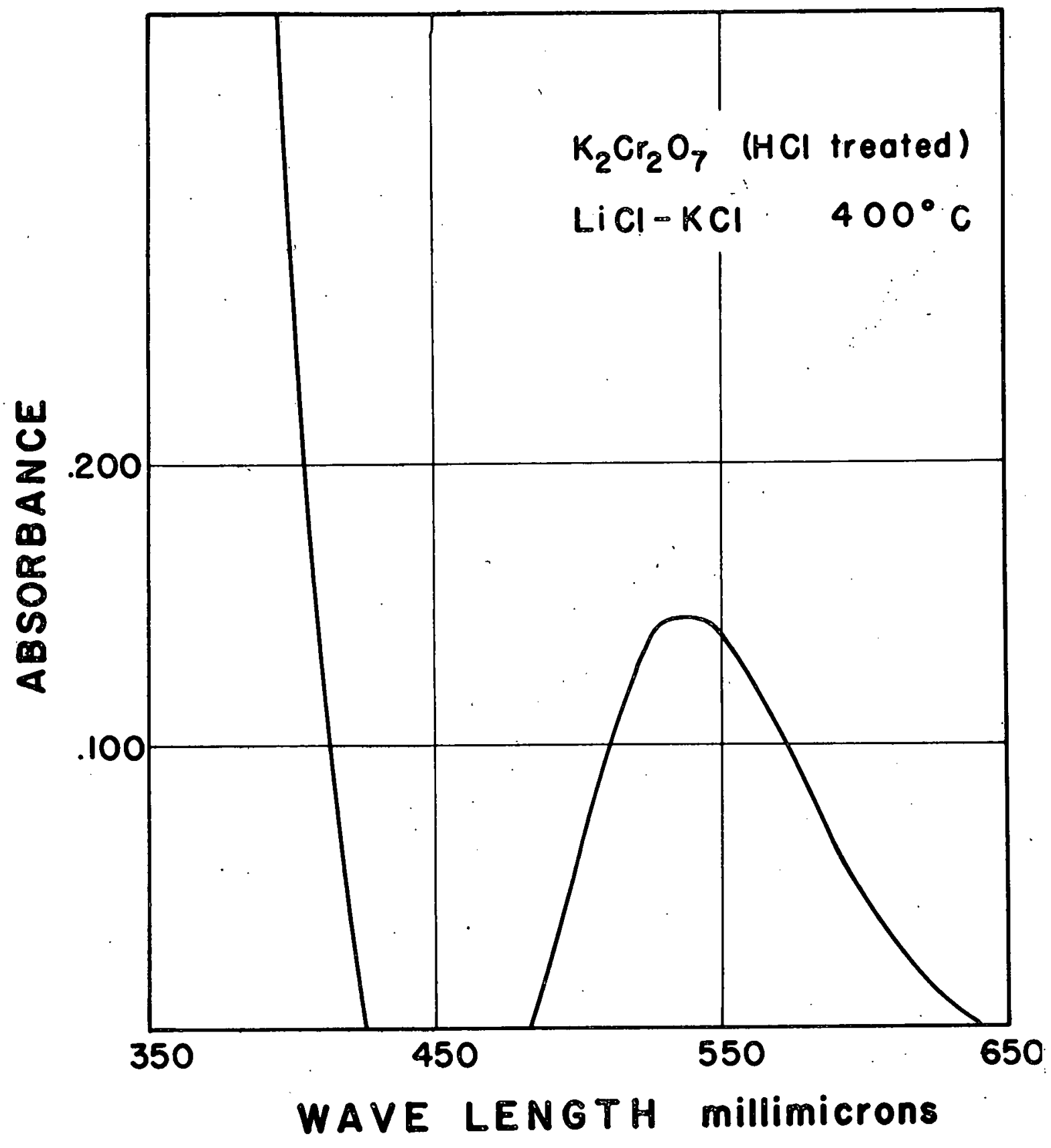

Figure 30

$$
\begin{gathered}
\text { Spectrum of } \mathrm{K}_{2} \mathrm{Cr}_{2} \mathrm{O}_{7}, \mathrm{HCl} \text { treated, } \\
\text { in LiCl-KCl }
\end{gathered}
$$


calculated using a molar extinction coefficient of 3300 at $370 \mathrm{mp}$, at $275^{\circ} \mathrm{C}$. The lead concentrations were calculated from the original chromate ion concentration assuming $a K_{\mathrm{gp}}$ of $1.62 \times 10^{-7}$ at $275^{\circ} \mathrm{C}$. This solubility product was checked using varying concentrations of lead ion; over four runs the solubility product determined was $1.62 \pm 0.02 \times 10^{-7}$. Table III gives the experimental values obtained, the calculated $F$ functions and the values of $k_{1}, k_{2}$ and $k_{3}$ found from the graphs.

Table III

Determinations of Formation Constants for Lead-Chloro Complexes in $\mathrm{KaVO}_{3}-\mathrm{NaNO}_{3}$

\begin{tabular}{|c|c|c|c|c|c|c|c|}
\hline $\begin{array}{l}\text { Moles } \mathrm{Cl}^{-} \\
/ 1000 \mathrm{~g} \text {. }\end{array}$ & $\begin{array}{l}\text { Absorbance } \\
\text { at } 370 \mathrm{~mm}\end{array}$ & {$\left[\begin{array}{c}\mathrm{CrO}_{4} \\
\mathrm{xlO}_{4}\end{array}\right]$} & {$\left[\begin{array}{c}\left.\mathrm{Pb}_{\text {total }}\right] \\
\mathrm{x}+104\end{array}\right.$} & $\mathrm{K}_{\mathrm{sp}} / \mathrm{K}_{\mathrm{sp}}$ & $\mathrm{F}_{1}$ & $\mathrm{~F}_{2}$ & $F_{3}$ \\
\hline Run 1 & & & Run I & & & & \\
\hline $\begin{array}{l}0.000 \\
0.050 \\
0.102 \\
0.147 \\
0.206\end{array}$ & $\begin{array}{c}0.225 \\
0.343 \\
0.489 \\
0.665 \\
0.999 \\
k_{1}=11.5\end{array}$ & $\begin{array}{l}1.72 \\
2.61 \\
3.72 \\
5.05 \\
7.56 \\
k_{3}=3.0\end{array}$ & $\begin{array}{r}9.41 \\
10.30 \\
11.41 \\
12.74 \\
15.23 \\
z_{2}=2.5\end{array}$ & $\begin{array}{l}1 \\
1.66 \\
2.62 \\
3.98 \\
7.12\end{array}$ & $\begin{array}{l}13 . . \\
13.5 \\
16.1 \\
20.4 \\
29.6\end{array}$ & $\begin{array}{l}40 . \\
45 \\
60 \\
86\end{array}$ & $\begin{array}{l}\ddot{110} \\
106 \\
173 \\
250\end{array}$ \\
\hline $\begin{array}{l}\frac{\text { Bun 2 }}{0.000} \\
0.040 \\
0.080 \\
0.131 \\
0.173 \\
0.204\end{array}$ & $\begin{array}{c}0.215 \\
0.293 \\
0.410 \\
0.623 \\
0.788 \\
0.923 \\
k_{1}=9.7\end{array}$ & $\begin{array}{l}1.63 \\
2.22 \\
3.11 \\
4.73 \\
5.98 \\
7.00 \\
k_{2}=3.5\end{array}$ & $\begin{array}{r}9.95 \\
10.60 \\
11.45 \\
13.05 \\
14.32 \\
15.32 \\
k_{3}=13.2\end{array}$ & $\begin{array}{l}1 \\
1.47 \\
2.21 \\
3.78 \\
5.28 \\
6.65\end{array}$ & $\begin{array}{l}11.8 \\
15.2 \\
21.2 \\
24.8 \\
27.4\end{array}$ & $\begin{array}{l}52 \\
69 \\
95 \\
87 \\
89\end{array}$ & $\begin{array}{l}450 \\
440 \\
460 \\
300 \\
270\end{array}$ \\
\hline $\begin{array}{l}\text { Run } 3 \\
0.000 \\
0.040 \\
0.080 \\
0.120 \\
0.158\end{array}$ & $\begin{array}{c}0.169 \\
0.252 \\
0.353 \\
0.468 \\
0.576 \\
k_{1}=12.6\end{array}$ & $\begin{array}{c}1.27 \\
1.91 \\
2.68 \\
3.56 \\
4.38 \\
k_{2}=4.4 .4\end{array}$ & $\begin{array}{l}12.7 \\
13.4 \\
14.1 \\
114.9 \\
15.8 \\
k_{3}=0\end{array}$ & $\begin{array}{l}1 \\
1.59 \\
2.34 \\
3.27 \\
4.28\end{array}$ & $\begin{array}{l}\ddot{1} 4.0 \\
16.8 \\
18.7 \\
20.6\end{array}$ & $\begin{array}{l}\ddot{53} \\
53 \\
51 \\
53\end{array}$ & $\begin{array}{l}\ddot{0} \\
0 \\
0 \\
0\end{array}$ \\
\hline
\end{tabular}


The absorbance readings listed in the above table have been corrected for light absorbance of solid lead chromate by subtracting the absorbance found at $500 \mathrm{mp}$. A sample of the graphical procedure is illustrated in Fig. 31.

(b) Lead-Bromo Complexes.- The solubilities of lead chromate as a function of added bromide ion, in the absence of excess lead ion, was determined spectrophotometrically at $275^{\circ} \mathrm{C}$. Table IV gives the results of these determinations.

Table IV

Solubilities of Lead Chromate as a Function of Added Bromide

\begin{tabular}{lll}
$\begin{array}{l}\text { Moles } \mathrm{Br}^{-} \\
/ 1000 \mathrm{~g} \cdot\end{array}$ & $\begin{array}{l}\text { Absorbance } \\
\text { at } 370 \mathrm{mp}\end{array}$ & $\begin{array}{l}\text { Solubility } \\
\text { of } \mathrm{PbCrO} \\
\text { in } \mathrm{mg} \cdot / \mathrm{g} .\end{array}$ \\
\hline 0.000 & 0.502 & 0.130 \\
0.0505 & 0.746 & 0.180 \\
0.0995 & 0.827 & 0.214 \\
0.152 & 1.045 & 0.256 \\
0.202 & 1.246 & 0.300 \\
0.225 & 1.550 & 0.380 \\
\hline
\end{tabular}

The solubilities of lead chromate, in the presence of excess lead ion were determined spectrophotometrically, the F functions calculated and $k_{1}$ and $k_{2}$ determined graphically in the same manner as for the lead-chloro complexes. Table $\nabla$ summarizes these results. 


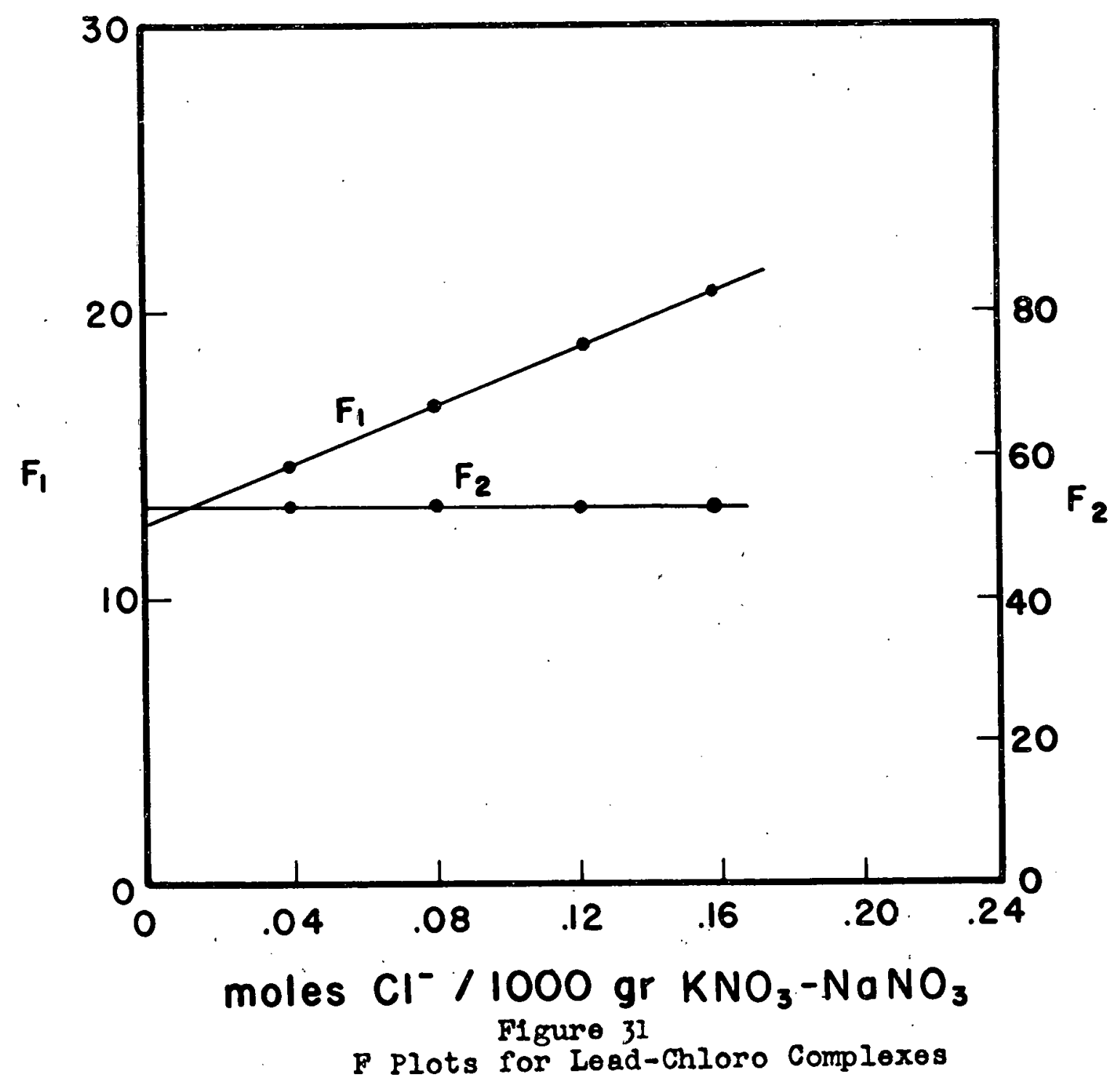


Table V

Determination of Formation Constants

for Lead-Bromo Complexes

\begin{tabular}{|c|c|c|c|c|c|c|}
\hline $\begin{array}{l}\text { Moles } \mathrm{Br}^{-} \\
/ 1000 \mathrm{~g} \text {. }\end{array}$ & $\begin{array}{l}\text { Absorbance } \\
\text { at } 370 \mathrm{m \mu}\end{array}$ & {$\left[\begin{array}{c}\left.\mathrm{CrO}_{4}=\right] \\
\left.\mathrm{Cb}_{\text {total }}=\right]\end{array}\right.$} & $\mathrm{K}_{\mathrm{sp}}^{\prime} / \mathrm{K}_{\mathrm{sp}}$ & $F_{1}$ & $\mathrm{~F}_{2}$ & $\mathrm{~F}_{3}$ \\
\hline
\end{tabular}

Run 1

$\begin{array}{llllllll}0.000 & 0.064 & 0.488 & 33.4 & 1 & \ldots . .9 & \ldots \ddot{1} & 30 \\ 0.040 & 0.106 & 0.805 & 33.7 & 1.68 & 16.9 & 96 & 388 \\ 0.080 & 0.172 & 1.31 & 34.2 & 2.76 & 22.1 & 114 & 420 \\ 0.120 & 0.274 & 2.08 & 35.0 & 4.49 & 29.0 & 133 & 436 \\ 0.160 & 0.412 & 3.14 & 36.1 & 7.00 & 37.5 & 154 & 460 \\ 0.200 & 0.560 & 4.25 & 37.1 & 9.76 & 43.6 & 150 & 340 \\ & k_{1}=13.0 & k_{2}=6.2 & k_{3}=4.7 & & & & \end{array}$

Run 2

0.000

$$
0.132
$$

1.00

16.2

$1.60 \quad 16.8$

1

0.040

0.211

0.000

0.324

0.120

0.472

2.46

17.7

3.59

18.8

1.66

2.69

4.16

$4.96 \quad 20.2$

6.18

$6.15 \quad 22.4$

0.200

0.652

$k_{2}=5.9 \quad k_{3}=3.9$

8.51

$\mathrm{k}_{1}=1.30$

Run 3

$\begin{array}{llllllll}0.000 & 0.133 & 1.01 & 16.0 & 1 & \ldots . . & \ldots .3 & \ldots \\ 0.040 & 0.218 & 1.66 & 16.7 & 1.70 & 17.5 & 88 & 150 \\ 0.080 & 0.330 & 2.51 & 17.5 & 2.71 & 21.4 & 93 & 138 \\ 0.120 & 0.485 & 3.69 & 18.7 & 4.26 & 27.2 & 109 & 220 \\ 0.160 & 0.650 & 4.94 & 19.9 & 6.08 & 31.8 & 112 & 186 \\ 0.200 & 0.836 & 6.36 & 21.4 & 8.40 & 37.0 & 115 & 164 \\ & k_{1}=14.0 & k_{2}=5.9 & k_{3}=1.9 & & & & \end{array}$

Figure 32 provides an example of the graphical determination of $k_{1}$ and $k_{2}$.

5. Lead-Iodo Complexes -- The use of the method previously described for the determination of the formation constants of the leadbromo and lead-chloro complexes is not valid for the lead-iodo complexes, 


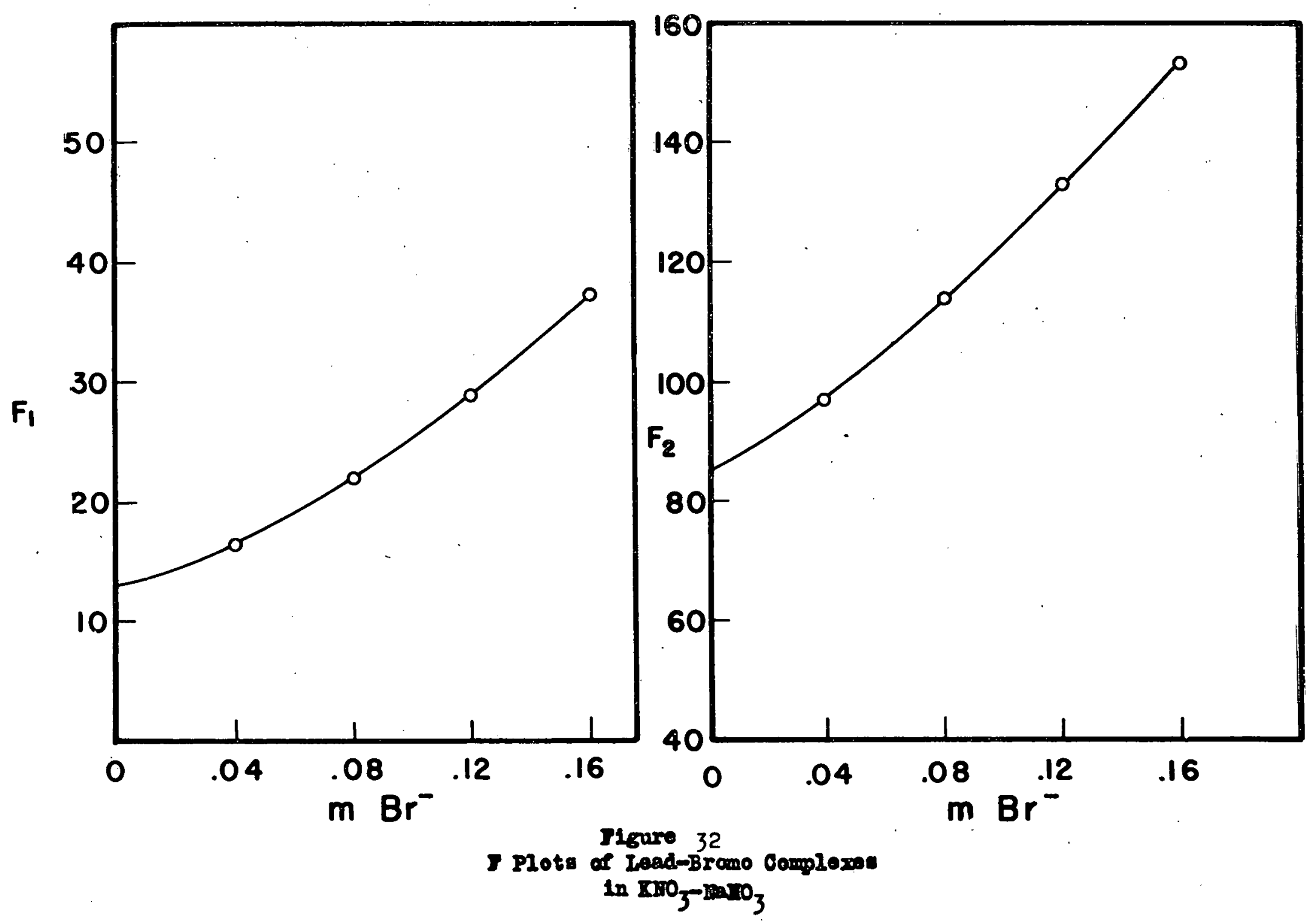


because the color of lead-iodide mixtures in the nitrate melt is yellow, and interfers with the determination of the yellow chromate ion. It was further found that the melt slowly oxidizes the iodide ion to form iodine, and the study of this system was therefore discontinued.

\section{B. Gas Evolution Investigations}

1. Mass Spectral Studies of the Products of the Dichromate-Nitrate Reaction in Fused $\mathrm{KNO}_{3}-\mathrm{NaNO}_{3} \cdot-$ The gaseous products of the reaction of dichromate ion with nitrate ion, in the presence of barium ion, were examined for constituents and relative amounts of each constituent. Standard patterns for $\mathrm{NO}, \mathrm{N}_{2} \mathrm{O}, \mathrm{NO}_{2}$ and $\mathrm{O}_{2}$ were taken on the mass spectrometer used and the patterns calculated on a basis cf the percentage of the reference peak. Table VI gives the patterns obtained, and the sensitivity of the reference peak. The sensitivity of the reference peak is defined as the height of the reference peak in arbitrary units, in this case millimeters on the recording chart, per micron of pressure of the gas. Therreference peak and the sensitivity were used for calculations of amounts of gas.

The products of the reaction were analyzed in two separatte runs; in each case the initial products and the products after 30 mimutes were analyzed. The sampling technique has been previously described. Table VII gives the mass spectral patterns obtained, corrected for background. 
Table VI

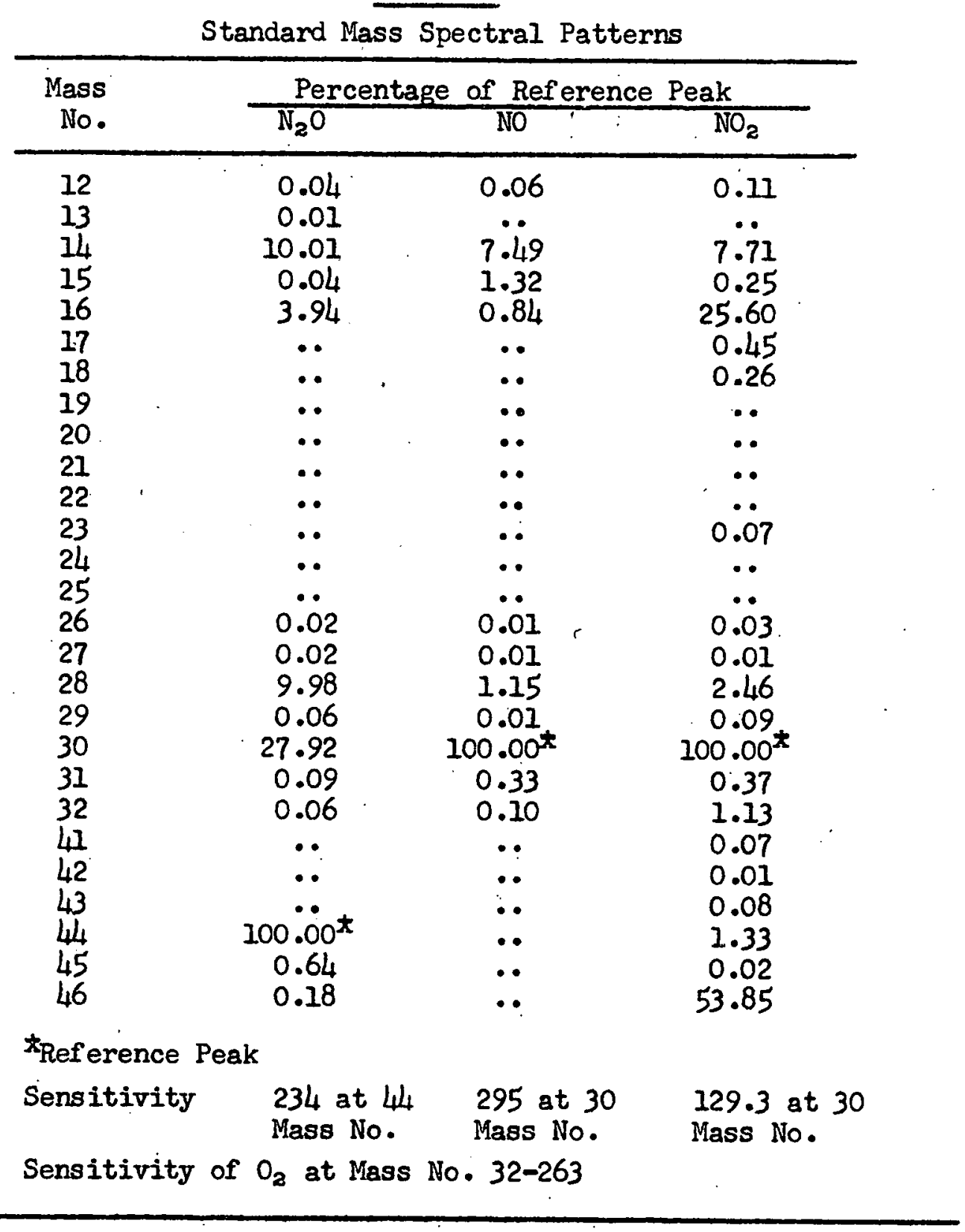


Table VII

Mass Spectral Patterns of Reaction Products ${ }^{\star}$.

\begin{tabular}{|c|c|c|c|c|}
\hline \multirow[b]{2}{*}{$\begin{array}{l}\text { Mass } \\
\text { No. }\end{array}$} & \multicolumn{2}{|c|}{ Run 1} & \multicolumn{2}{|c|}{ Run 2} \\
\hline & $\begin{array}{l}\text { Initial } \\
\text { Products }\end{array}$ & $\begin{array}{l}\text { After } 30 \\
\text { min. }\end{array}$ & $\begin{array}{l}\text { Initial } \\
\text { Products }\end{array}$ & $\begin{array}{c}\text { After } 30 \\
\text { min. }\end{array}$ \\
\hline $\begin{array}{l}12 \\
14 \\
16 \\
17 \\
18 \\
22 \\
23 \\
28 \\
30 \\
32 \\
44 \\
46\end{array}$ & $\begin{array}{c}60.4 \\
733 \\
2450 \\
323 \\
992 \\
10.5 \\
5.0 \\
469 \\
9879 \\
3698 \\
962 \\
4070\end{array}$ & $\begin{array}{c}10.5 \\
732 \\
2900 \\
84 \\
160 \\
\ddot{6.1} \\
261 \\
9509 \\
5117 \\
68 \\
4990\end{array}$ & $\begin{array}{c}31 \\
700 \\
2684 \\
212 \\
595 \\
5.0 \\
5.4 \\
533 \\
9188 \\
4661 \\
490 \\
4410\end{array}$ & $\begin{array}{c}12 \\
714 \\
2885 \\
100 \\
303 \\
.0 .0 \\
349 \\
9448 \\
5251 \\
100 \\
4860\end{array}$ \\
\hline
\end{tabular}

Table III lists the results of the interpretation of the mass spectral patterns, giving the mole percent of each gas present and the calculated $0: N$ ratios.

Table VIII

Analysis of Reaction Products

\begin{tabular}{cccccc}
\hline Mole $\%$ & \multicolumn{2}{c}{ Initial Products } & & \multicolumn{2}{c}{$\begin{array}{c}\text { Products af ter } \\
30 \text { min. }\end{array}$} \\
\cline { 2 - 3 } & Melt 1 & Melt 2 & & Melt I & Melt 2 \\
\hline $\mathrm{N}_{2} \mathrm{O}$ & 4.4 & 1.9 & $\ldots$ & $\ldots$ \\
$\mathrm{NO}$ & 8.6 & 3.5 & & 1.3 & 1.2 \\
$\mathrm{NO}_{2}$ & 70.5 & 74.2 & & 77.9 & 77.2 \\
$\mathrm{O}_{2}$ & 16.5 & 20.4 & & 20.8 & 21.6 \\
$0: \mathrm{N}$ ratin & $1.24: 2$ & $4.78: 2$ & $5.02: 2$ & $5.06: 2$ \\
\hline
\end{tabular}


As can be seen from the analysis, the final $0: N$ ratios are 5:2, within the limits of measurements of the instrument used. Small amounts of water vapor were detected (Iess than $1 \%$ total pressure) and were ignored for purposes of calculation of the $0: N$ ratios.

2. Determination of Acidic Oxy-Anions in Fused Salts by $\mathrm{CO}_{2}$ Evolution.- (a) Determination of $\mathrm{K}_{2} \mathrm{Cr}_{2} \mathrm{O}_{7}$ in $\mathrm{KNO}_{3}-\mathrm{NaNO}_{3}$ - The volume of the system was calibrated by expansion of argon at a known volume and pressure into the static system. Known amounts of $\mathrm{K}_{2} \mathrm{Cr}_{2} \mathrm{O}_{7}$, and in some cases $\mathrm{K}_{2} \mathrm{CrO}_{4}$, were added to a known amount of $\mathrm{KNO}_{3}-\mathrm{NaNO}_{3}$ eutectic in the manner previously described. Sodium carbonate was added to the molten salts while the static system was evacuated. The number of moles of $\mathrm{CO}_{2}$ evolved was calculated from the ideal gas law. A correction was applied for the volume of the melt. Mass spectral analys is showed only $\mathrm{CO}_{2}$ in the evolved gas. Addition of $\mathrm{Na}_{2} \mathrm{CO}_{3}$ to the pure eutectic melt caused no pressure change in the system. Table IX shows a sample calculation of the volume of the system and of the number of moles of $\mathrm{CO}_{2}$ evolved during a determination.

\section{Table IX}

Sample Calculations

\section{Calibration of System}

$\begin{array}{ll}\text { Volume of calibrated bulb } & -0.106 \text { liters } \\ \text { Pressure of calibrated bulb } & -607.4 \mathrm{~mm} . \mathrm{Hg} \\ \text { Pressure of system after expansion }-80.3 \mathrm{~mm} . \mathrm{Hg} \\ \text { Volume of system, calculated } & -0.802 \text { liters }\end{array}$

Evolution of $\mathrm{CO}_{2}$

$\begin{array}{ll}\text { Volume of system } & -0.802 \text { liters } \\ \text { Weight of melt } & -50 \mathrm{~g} \cdot \\ \text { Density of melt } & -2.0 \\ \text { Volume of melt } & -0.035 \text { liters } \\ \text { Correctid volume of system } & -0.777 \text { liters } \\ \text { Pressure of } \mathrm{CO}_{2} \text { evolved } & -66.2 \mathrm{~mm} . \mathrm{Hg} \\ \text { Temperature of static system } & -28^{\circ} \mathrm{C}\end{array}$

No. moles of $\mathrm{CO}_{2}=\mathrm{PV} / \mathrm{RT}=66.2 \times 0.777 / 760.0 \times 0.082 \times 301.7=2.74 \times 10^{-3}$ moles. 
Table X lists the results of six determinations of $\mathrm{K}_{2} \mathrm{Cr}_{2} \mathrm{O}_{7}$ in fused $\mathrm{KNO}_{3}-\mathrm{NaNO}_{3}$ eutectic at $300 \pm 5^{\circ} \mathrm{C}$.

Table X

Determination of $\mathrm{K}_{2} \mathrm{Cr}_{2} \mathrm{O}_{7}$ in $\mathrm{KNO}_{3}-\mathrm{NaNO}_{3}$ Eutectic

\begin{tabular}{ccccc}
$\begin{array}{c}\text { Sample } \\
\text { No. }\end{array}$ & $\begin{array}{c}\mathrm{K}_{2} \mathrm{CrO}_{4} \\
\text { mole taken }\end{array}$ & $\begin{array}{c}\mathrm{K}_{2} \mathrm{Cr}_{2} \mathrm{O}_{7} \\
\text { m mole taken }\end{array}$ & $\begin{array}{c}\mathrm{K}_{2} \mathrm{Cr}_{2} \mathrm{O}_{7} \\
\text { m mole } \\
\text { determined }\end{array}$ & $\begin{array}{c}\dot{\phi} \\
\text { Error }\end{array}$ \\
\hline 1 & $\cdots$ & 3.41 & 3.42 & 0.3 \\
2 & $\cdots$ & 3.49 & 3.49 & $\cdots$ \\
3 & $\ddot{4}$ & 4.20 & 4.21 & 0.3 \\
4 & 3.58 & 1.82 & 1.82 & $\cdots$ \\
5 & 1.19 & 2.72 & 2.72 & $\cdots$ \\
6 & 5.50 & 3.05 & 3.04 & -0.3 \\
\hline
\end{tabular}

In all cases the reactions were allowed to continue until no further pressure change could be detected. $\mathrm{NaPO}_{3}$ and $\mathrm{K}_{2} \mathrm{~S}_{2} \mathrm{O}_{7}$ were also considered for this type of determination but both react with the nitrate melt evolving oxides of nitrogen.

(b) Determination of $\mathrm{K}_{2} \mathrm{Cr}_{2} \mathrm{O}_{7}, \mathrm{NaPO}_{3}$ and $\mathrm{NaVO}_{3}$ in LiCl-KCl Eutectic.- Similar determirations of $\mathrm{K}_{2} \mathrm{Cr}_{2} \mathrm{O}_{7}, \mathrm{NaPO}_{3}$ and $\mathrm{NaVO}_{3}$ were made in the $\mathrm{LiCl}-\mathrm{KCl}$ eutectic at $400^{\circ} \mathrm{C}$. The procedure for these determinations has already been described. Table XI gives the results of these determinations. 
Tabie XI

Determinations of Acidic Oxy-Anions in $\mathrm{LiCl}-\mathrm{KCl}$ Eutectic

\begin{tabular}{|c|c|c|c|}
\hline $\begin{array}{l}\text { Sample } \\
\text { No. }\end{array}$ & $\begin{array}{l}\text { M-moles Acid } \\
\text { added }\end{array}$ & $\begin{array}{l}\text { M-moles Acid } \\
\text { Determined }\end{array}$ & \% Error \\
\hline \multicolumn{4}{|c|}{$\mathrm{K}_{2} \mathrm{Cr}_{2} \mathrm{O}_{7}$ Determinations } \\
\hline $\begin{array}{l}1 \\
2 \\
3\end{array}$ & $\begin{array}{l}1.92 \\
1.90 \\
2.53\end{array}$ & $\begin{array}{l}1.93 \\
1.91 \\
2.50\end{array}$ & $\begin{array}{r}0.5 \\
0.5 \\
-1.0\end{array}$ \\
\hline \multicolumn{4}{|c|}{$\mathrm{NaPO}_{3}$ Determinations } \\
\hline $\begin{array}{l}1 \\
2 \\
3\end{array}$ & $\begin{array}{l}3.16 \\
1.57 \\
3.07\end{array}$ & $\begin{array}{l}3.06 \\
1.52 \\
3.05\end{array}$ & $\begin{array}{l}-3 \\
-3 \\
-0.7\end{array}$ \\
\hline \multicolumn{4}{|c|}{$\mathrm{NaVO}_{3}$ Determinations } \\
\hline$\frac{1}{2}$ & $\begin{array}{l}3.32 \\
3.29\end{array}$ & $\begin{array}{l}3.31 \\
3.27\end{array}$ & $\begin{array}{l}-0.3 \\
-0.7\end{array}$ \\
\hline
\end{tabular}

An attempt was made to determine $\mathrm{K}_{2} \mathrm{~S}_{2} \mathrm{O}_{7}$ in the chloride melt but the reagent contained $\mathrm{KHSO}_{4}$ which reacted with the melt to yield $\mathrm{HCl}$ gas.

\section{Acid-Base Reactions in Fused Salts}

Various qualitative experiments were performed to investigate acid-base behavior in fused salts and the relation of acid-base reactions to oxidation-reduction processes in these melts. şimall amounts of the reagents used were added to the melts contained in test tubes and the results were observed visually. Table XII is a summary of such observations. 
Table XII

Qualitative Observations of Reactions in Fused Salts

\begin{tabular}{|c|c|c|c|}
\hline Solvent & & Reagents Added & Result \\
\hline \multicolumn{2}{|c|}{$\mathrm{KNO}_{3}-\mathrm{NaNO}_{3}$ Eutectic } & $\mathrm{KI}$ & no reaction \\
\hline \multirow{10}{*}{\multicolumn{2}{|c|}{ ' }} & $\mathrm{CoCl}_{2}$ & purple melt \\
\hline & & $\mathrm{KI}+\mathrm{CoCl}_{2}$ & $I_{2}$ evolved \\
\hline & & $\mathrm{NaPO}_{3}$ & $\begin{array}{l}\text { oxides of nitrogen } \\
\text { evolved }\end{array}$ \\
\hline & & $\mathrm{KI}+\mathrm{NaPO}_{3}$ & $\begin{array}{l}\mathrm{I}_{2} \text { and oxides of } \\
\text { nitrogen evolved }\end{array}$ \\
\hline & & $\mathrm{NaVO}_{3}$ & reagent insoluble \\
\hline & & $\mathrm{KI}+\mathrm{Na}_{2} \mathrm{CO}_{3}$ & no reaction \\
\hline & & $\mathrm{KI}+\mathrm{NiCl}_{2}$ & $I_{2}$ evolved \\
\hline & & $\mathrm{KBr}+\mathrm{NiCl}_{2}$ & $\mathrm{Br}_{2}$ evolved \\
\hline & & $\mathrm{MnCl}_{2}$ & brown $\mathrm{MnO}_{2}$ formed \\
\hline & & $\mathrm{MnCl}_{2}+\mathrm{NaPO}_{3}$ & $\begin{array}{l}\text { permanganate ion } \\
\text { formed }\end{array}$ \\
\hline \multirow[t]{7}{*}{$\mathrm{LiCl}-\mathrm{KCl}$} & Eutectic & $\mathrm{K}_{2} \mathrm{Cr}_{2} \mathrm{O}_{7}$ & no reaction \\
\hline & & $\mathrm{K}_{2} \mathrm{Cr}_{2} \mathrm{O}_{7}+\mathrm{NaPO}_{3}$ & $C I_{2}$ evolved \\
\hline & & $\mathrm{KMnO}_{4}+\mathrm{KI}$ & $I_{2}$ evolved slowly \\
\hline & & $\mathrm{KMnO}_{4}+\mathrm{KI}+\mathrm{NaPO}_{3}$ & $I_{2}$ evolved rapidly \\
\hline & & $\mathrm{KNO}_{3}$ & no reaction \\
\hline & r & $\mathrm{NaPO}_{3}+\mathrm{KNO}_{3}$ & $\begin{array}{l}\text { oxides of nitrogen } \\
\text { evolved }\end{array}$ \\
\hline & . & $\mathrm{K}_{2} \mathrm{Cr}_{2} \mathrm{O}_{7}+\mathrm{HCl}$ (gas) & $\begin{array}{l}\mathrm{Cl}_{2} \text { evolved and melt } \\
\text { turned purple }\end{array}$ \\
\hline
\end{tabular}




\section{DISCUSSION OF RESULTS}

\section{A. Spectrophotometric Investigations}

1. Spectral Studies of the Cobalt-Halide Complexes in $\mathrm{LiNO}_{3}-\mathrm{KNO}_{3}$ Eutectic.- (a) Cobalt-Chloro Complexes.- The method of continuous variation does not yield any conclusive information on the complex ions formed by chloride ions with cobalt(II) ions. In Fig. 11 , the maximum at 0.8 mole fraction of chloride Ion indicates a probability of a 4:I complex of chloride ions with cobalt(II) ions. This is calculated from the equation

$$
n=x /(1-x)
$$

where $\underline{n}$ is the number of ligands attached to the central ion, see Part II,D. This complex has been postulated by Gruen but has not been definitely established. The location of the other maximum is too variable to enable the postulation of any particular complex ion. The inadequacies of this method can be attributed to several factors. First, the formation constants of the cobalt-chloro complexes are too small to cause sufficiently large spectral shifts. Gruen has shown that a large excess of chloride ion is necessary to shift the spectral peaks of cobalt(II) solutions radically. Secondly, it is difficult to maintain accurately the concentrations of cobalt(II) in this eutectic, because $\mathrm{Co}_{2} \mathrm{O}_{3}$ is slowly precipitated from solution. The $\mathrm{LiNO}_{3}-\mathrm{KNO}_{3}$ eutectic absorbs water from the atmosphere rapidly, even when the eutectic is predried and fused under vacuum. Duke has 
found that lithium salts absorb water very rapidly. ${ }^{37}$ Thirdly, the concentration range that can be handled experimentally. with any degree of accuracy is fairly small, even using. $2 \mathrm{~mm}$. cells. The maximum concentration that could be measured was $1.94 \times 10^{-2}$ moles per liter. At this concentration the absorbance values are not considered accurate since the values obtained are above 1.0 .

The method of MeConnell and Davidson, as applied to the cobalt-chloro complexes, resulted in a large scattering of data. It can be seen from Fig. 13 that no single straight line can reasonably be drawn through the points obtained. The variation of $k_{1}$ from 40 to over $300^{\circ}$ can be explained by consideration of the effect of errors in composition or in measurement on the value of $k_{1}$. Error analysis shows that a $1 \%$ error in the estimate of the concentration of cobalt ion in solution results in an error in $k_{1}$ of 100 . An error of $1 \%$ in the absorbance reading causes an error of 50 in $k_{1}$. Since the concentration of cobalt ion changes due to precipitation of cobaltic oxides and because the spectrophotometric procedure has an inherent inaccuracy of rather more than $1 \%$, it is apparent that the present application of the McConnell-Davidson technique to cobalt-chloro complexes is too inaccurate to justify further work with this system. However, it is possible to get an ibrder of magnitude" value for the first formation constant. Successful application of this method to other complex ion systems is quite possible, but depends upon the type of couplex 1ons formed and their spectral characteristics. 
(b) Cobalt-Bromo Complexes.- The spectral shifts noted on the addition of bromide ion to cobalt(II) solutions are comparable to those encountered for cobalt-chloro complexes where any method tried would have the same inherent errors and difficulties as for the cobalt-chloro complexes.

\section{Spectral Studies of Chromium Salts in Various Nitrate}

Melts.- (a) Lithium Nitrate-Potassium Nitrate Eutectic.- The spectrum of pure $\mathrm{LiNO}_{3}-\mathrm{KNO}_{3}$ eutectic found in the present work is in agreement with that found by Greenberg and Sundheim. ${ }^{6}$ The spectra of $\mathrm{CrCl}_{3}, \mathrm{~K}_{2} \mathrm{CrO}_{4}$ and $\mathrm{K}_{2} \mathrm{Cr}_{2} \mathrm{O}_{7}$ are identical in this melt and must be attributed to the same species. The spectrum of chromate ion in basic aqueous solution is very similar to the spectra found in the eutectic, indicating that the species present is the chromate ion in all cases. There are several possible explanations for the occurrence of only one species. Small amounts of water in the nitrate melt could react with the melt to yield oxide ion which in turn would react with the dichromate ion giving two chromate ions, as in the following equations.

$$
\begin{aligned}
\mathrm{H}_{2} \mathrm{O}+2 \mathrm{LiNO}_{3} & \longrightarrow \mathrm{Li}_{2} \mathrm{O}+2 \mathrm{HNO}_{3}{ }^{-} \\
\mathrm{Li}_{2} \mathrm{O}+\mathrm{Cr}_{2} \mathrm{O}_{7}= & \longrightarrow 2 \mathrm{CrO}_{4}=+2 \mathrm{Li}^{+}
\end{aligned}
$$

The $\mathrm{CrCl}_{3}$ is oxidized to the chromate form, the following equation representing the reaction

$$
\mathrm{Cr}(\mathrm{III})+5 \mathrm{NO}_{3}-\longrightarrow \mathrm{CrO}_{4}=+3 \mathrm{NO}_{2}+\mathrm{N}_{2} \mathrm{O}_{5}
$$


Another possibility for the existence of only the chromate form in this melt is a possible equilibrium of chromate and dichromate with the nitrate ion in the following manner:

$$
\begin{aligned}
& \mathrm{Cr}_{2} \mathrm{O}_{7}=+\mathrm{NO}_{3}^{-} \rightleftarrows 2 \mathrm{CrO}_{4}=+\mathrm{NO}_{2}^{+} \\
& \mathrm{NO}_{2}^{+}+\mathrm{NO}_{3}^{-} \rightleftarrows \mathrm{N}_{2} \mathrm{O}_{5}
\end{aligned}
$$

Duke and Iverson have concluded that in the $\mathrm{KNO}_{3}-\mathrm{NaNO}_{3}$ eutectic at a higher temperature, the equilibrium. lies far to the left as barium ion is needed to force the reaction to the right by precipitating the chromate form. No experimental evidence was found in this investigation for the existence of such an equilibrium in the $\mathrm{LiNO}_{3}-\mathrm{KNO}_{3}$ eutectic. The difficulty arises in determining the existence of the $\mathrm{NO}_{2}^{+}$ion in the nitrate melt.

The differential spectrum is attributed to that of the dichromate ion as in high concentrations the solutions in the melt had the characteristic orange color of dichromate ion which sharply changed to yellow upon the addition of sodium carbonate. Evidently, some of the dichromate is converted to chromate, but not all, and by using the differential technique it is possible to obtain the spectra of the dichromate ion.

(b) Silver Nitrate.- The spectra found in silver nitrate for all three chromium salts, $\mathrm{CrCl}_{3}, \mathrm{~K}_{2} \mathrm{CrO}_{4}$ and $\mathrm{K}_{2} \mathrm{Cr}_{2} \mathrm{O}_{7}$, are identical and are attributed to the dichromate ion. The following reaction shows how chromate inn nnuld be convertod to diehromate iun.

$$
2 \mathrm{Ag}^{+}+2 \mathrm{CrO}_{4} \longrightarrow \mathrm{Cr}_{2} \mathrm{O}_{7}=+\mathrm{Ag}_{2} \mathrm{O}
$$


Korcies et al., using freezing point neasurements, demonstrated that the dichromate ion does indeed exist in silver nitrate. ${ }^{36}$ The spectral peak found for this dichromate form occurs at a wavelength very close to that found by the differential technique in $\mathrm{LiNO}_{3}-\mathrm{KNC}_{3}$.

The Beer's Law plot shows that the dichromate ion behaves in a manner predicted by theory. The extinction coefficients were calculated using a density for the melt of 3.86 and are considered to be accurate to within $\pm 5 \%$. $^{39}$

(c) Potassium Nitrate-Sodium Nitrate Eutectic.- The $\mathrm{KNO}_{3}-\mathrm{NaNO}_{3}$ eutectic exhibits properties closely similar to the $\mathrm{LiNO}_{3}-\mathrm{KNO}_{3}$ eutectic in that small concentrations of the chromium salts yield the spectra of the chromate ion while higher concentrations of dichromate ion show the color of the dichromate ion.

The concentrations of the chromium salts used for the spectrophotometric measurements were of the order of $10^{-4}$ moles per $1000 \mathrm{~g}$. of eutectic. The existence of concentrations of impurities such as oxide ion in the melts of this order of magnitude is quite possible and would be difficult to eliminate. An equilibrium constant for the reaction of dichromate ion with nitrate ion to give chromate ion and nitronium ion could not be evaluated because in no case could small amounts of chromate ion and dichromate ion be detected simultaneously, and the nitronium ion could not be detected directly. The peaks of the differential spectra show shifts toward longer. wavelengths. These shifts oan be explained by the following 
considerations. As the concentration of added dichromate ion is increased, the proportion of dichromate ion converted to chromate ion by impurities becomes smaller. Thus each successive spectrum would have proportionately more dichromate. ion contributing to the absorption, with a resultant movement of the peak of the differential spectrum to a wavelength more closely in agreement with that of the dichromate ion alone, e.g., as in silver nitrate.

The Beer!'s Law plots show that the chromate ion behaves in the manner predicted. The extinction coefficients calculated are believed to be within $5 \%$ of the true value and agree well with those found by Boston and Smith in $\mathrm{KNO}_{3}$ at $362^{\circ} \mathrm{C} .^{14}$ These workers obtained an extinction coefficient of 3380 at the maximum while the present investigation resulted in a value of 3295 . This agreement is considered to be good, in view of the differences in temperature and solvent.

3. Spectral Studies of Chromium Salts in LiCl-KCl Eutectic The spectra obtained for the chromate and dichromate ions in the chloride melt emphasize the problem of obtaining the spectrum of the dichromate ion. It is apparent that $\mathrm{HCl}$ reacts with the dichromate ion to give chromic ion and chlorine as shown by the following equation.

$$
\mathrm{Cr}_{2} \mathrm{O}_{7}=+\mathrm{I}_{4} \mathrm{HCl} \longrightarrow 2 \mathrm{Cr}^{+3}+7 \mathrm{H}_{2} \mathrm{O}+8 \mathrm{Cl}^{-}+3 \mathrm{Cl}_{2}
$$

The addition of sodium metaphosphate to the chloride melt in an attempt to acidify the melt resulted in decoloration of the orange 
solution and a spectrum of a species exhibiting an absorption edge at $355 \mathrm{mp}$, namely chlorine. The absorption edge found agrees well with that found for chlorine by Greenberg and Sundheim.' The reason that the dichromate ion does not react with the chloride melt except in the presence of a strong acid such as metaphosphate ion will be discussed later.

\section{Spectrophotometric Determination of Formation Constants} of Iead-ChIoro and Lead-Bromo Complexes in $\mathrm{KNO}_{3}-\mathrm{NaNO}_{3} \cdot-$ (a) LeadChloro Complexes.- The method used as previously described has the inherent advantage that analytical determinations are performed "in situ. The results obtained for the formation constants of the first, three lead-chloro complexes indicate that $k_{1}$ has an average value of 11.6, $k_{2}$ of 3.6 and $k_{3}$ of 5.2 . The values agree with those obtained by Duke using an indirect procedure. ${ }^{16}$ He obtained values of 8,3 , and $I$ for $\ddot{k}_{1}, k_{2}$ and $k_{3}$ respectively. Using the method of successive intercepts, any error in the first formation constant will cause a larger error in the second formation constant, and so on. For this reason, the limits of error placed on $k_{1}$ are $\pm 20 \%$, on $k_{2}$ $\pm 50 \%$ and on $k_{3} \pm 100 \%$. The solubility product used in all calculations was $1.62 \times 10^{-7}$.

While the results of this Investigation do not agree with those of Van Artsdalen who found by a cryoscopic investigation that $\mathrm{PbCl}^{+}$was "hot thermodynamically important", one can compare the formation constant for the resotion

$$
\mathrm{Pb}^{+2}+2 \mathrm{Cl}^{-} \rightleftharpoons \mathrm{PbCl}_{2}
$$


obtained by Van Artsdalen with that found in this investigation, $k_{1} k_{2} \cdot 40$ Van Artsdalen obtained a formation constant of 30 while the results of this investigation at a temperature $30^{\circ}$ lower and in a slightly different solvent indicates a formation constant of 42 . A possible explanation for this disagreement concerning the existence of a $\mathrm{PbCl}^{+}$species is that the cryoscopic measurements are not sufficiently sensitive to detect the formation of a $\mathrm{PbCl}^{+}$species.

(b) Lead-Bromo Complexes.- The results of the determination of the formation constants for the first three lead-bromo complexes yield an average value of $k_{1}$ of 13.3, an average of $k_{2}$ of 6.0 and of $k_{3}$ of 3.5. These values are in reasonable agreement with those found by Duke of 13,2 and $1 .^{16}$ The estimated errors in the formation constants are the same as quoted for the lead-chloro complexes. It can be seen that the application of this method is valid only for those cases in which the anion of a sparingly soluble salt can be determined spectrophotometrically. Extension of this method to other compounds of dichromate and permanganate ions is possible.

5. Investigation of Lead-Iodo Complexes in $\mathrm{KNO}_{3}-\mathrm{NaNO}_{3} .-$ The present work indicates that lead-iodo complexes exist, but that they would be difficult to examine quantitatively because lead iodide is rather insoluble in the nitrate melt, and in the presence of lead ion iodide ion is slowly oxidized to iodine by the nitrate melt. 


\section{B. Gas Evolution Investigations}

1. Mass Spectral Studies of the Products of the DichromateNitrate Reaction in $\mathrm{KNO}_{3}-\mathrm{NaNO}_{3}$ Eutectic.- The results of the analys is of the gaseous products of the reaction of dichromate ion with nitrate ion, in the presence of barium ion in fused $\mathrm{KNO}_{3}-\mathrm{NaNO}_{3}$ eutectic show that $\mathrm{N}_{2} \mathrm{O}_{5}$ or its decomposition products are evolved. The reactions that are written to explain these results are:

$$
\begin{aligned}
& 2 \mathrm{Ba}^{++}+\mathrm{Cr}_{2} \mathrm{O}_{7}=+\mathrm{NO}_{3}^{-} \longrightarrow 2 \mathrm{BaCrO}_{4}+\mathrm{NO}_{2}^{+} \\
& \mathrm{NO}_{2}{ }^{+}+\mathrm{NO}_{3}^{-} \longrightarrow\left[\mathrm{N}_{2} \mathrm{O}_{5}\right] \rightarrow \text { decomposition } \\
& \text { products }
\end{aligned}
$$

while the summation of these reactions is

$$
2 \mathrm{Ba}^{++}+\mathrm{Cr}_{2} \mathrm{O}_{7}=+2 \mathrm{NO}_{3}^{-} \longrightarrow 2 \mathrm{BaCrO}_{4}+\left[\mathrm{N}_{2} \mathrm{O}_{5}\right] \longrightarrow \begin{aligned}
& \text { decomposition } \\
& \text { products of } \\
& \mathrm{N}_{2} \mathrm{O}_{5}
\end{aligned}
$$

This is an acid-base reaction with the dichromate ion abstracting an oxide ion from the nitrate ion yielding a nitronium ion and two chromate ions. The $\mathrm{NO}_{2}{ }^{+}$ion exists in perchloric, selenic and pyrosulfuric acid solutions of nitric acid, as shown by Raman spectroscopy.41,42 This ion also exists in surfuric acid solutions containing nitric acid. ${ }^{43}$ The analogy which can be drawn between concentrated acid solutions and acidic fused salt melts is now apparent. The sulfuric acid abstracts a water molecule from two nitric acid molecules leaving $\mathrm{N}_{2} \mathrm{O}_{5}$ in solution, in the form of $\mathrm{NO}_{2}^{+}$ and $\mathrm{NO}_{3}{ }^{-}$. In the case of the dichromate ion in the nitrate melt, it is necessary to enhance the acidic nature of the dichromate ion by adding a presipitant for the ehromate ivil, su forcing the reaction 
toward the basic form at an appreciable rate. The addition of sodium metaphosphate or potassium pyrosulfate to the nitrate melt yielded the oxides of nitrogen without any such addition of precipitant. This would imply either that each of these acids are stronger than the dichromate ion or that the insolubility of the phosphate ion or the sulfate ion aids in the reaction. However, it has been previously shown that addition of metaphosphate ion to a nitrate melt containing yellow chromate ion results in a conversion of the chromate ion to the orange dichromate ion, thus implying that metaphosphate ion is a stronger acid than dichromate ion. The lower and somewhat more variable $0: \mathrm{N}$ ratios determined for the gaseous products given off can be attributed to the presence of impurities in the melts such as nitrite ion. It is well known that at somewhat higher temperatures potassium and sodium nitrate decompose to give nitrite ion. Since a calculation of the amount of impurity, in the form of nitrite ion, needed to produce the observed ratios of $0: \mathbb{N}$ showed that less than $10^{-4}$ moles per thousand grams of eutectic was needed, it is not unreasonable to postulate nitrite ion as being the impurity.

2. Determination of Acidic Oxy-Anions in Fused Salts by $\mathrm{CO}_{2}$ Evolution.- (a) Determination of $\mathrm{K}_{2} \mathrm{Cr}_{2} \mathrm{O}_{7}$ in $\mathrm{KNO}_{3}-\mathrm{NaNO}_{3}$ EutecticThe determinations of dichromate ion in the $\mathrm{KNO}_{3}-\mathrm{NaNO}_{3}$ eutectic by measuring the number of moles of $\mathrm{CO}_{2}$ evolved when excess sodium carbonste was added to the melt were within $\pm 2 \%$ of the true value. 
It can be concluded, therefore, that the use of this method for an "in situll analysis is feasible and accurate. An extension of this method could be used to evaluate the oxide ion concentration in this nitrate melt by the addition of excess dichromate ion, which would react with oxide ion, and subsequent "back titration" of the dichromate ion with carbonate. Flood and co-workers have used a method similar to this in determining by $\mathrm{CO}_{2}$ evolution the species formed when $\mathrm{B}_{2} \mathrm{O}_{3}$ was added to various carbonate melts ${ }^{22}$

(b) Determinations of Acidic OxyAnions in LiCl-KCI Eutectic.The determinations of $\mathrm{K}_{2} \mathrm{Cr}_{2} \mathrm{O}_{7}, \mathrm{NaPO}_{3}$ and $\mathrm{NaVO}_{3}$ in the chloride eutectic appear quantitative and are considered to be accurate to within $\pm 3 \%$. Care must be taken in each case to ensure that all HCl gas used for drying the melt has previously been removed. This method may also be extended to include the analysis for oxide ion in this melt as discussed above.

\section{Acid-Base Relationships in Fused Salts}

Some comments on the experimental observations regarding the interrelation of acid-base reactions and oxidation-reduction processes are of interest. Duke and Iverson have shown that dichromate ion is not the oxidizing species in the oxidation of bromide to bromine in the $\mathrm{KNO}_{3}-\mathrm{NaNO}_{3}$ eutectic containing bromide ion and dichromate ion, but such oxidation is due to the $\mathrm{NO}_{2}^{+}$ion. 44 The dichromate ion functions as a Iux-Flood acid, reacting with the nitrate 
ion to produce the $\mathrm{NO}_{2}^{+}$ion. They demonstrated that this was so by showing that barium ion was needed for the oxidation of the bromide ion, thus indicating an acid-base reaction. They further postulated the existence of an intermediate species $\mathrm{NO}_{2} \mathrm{Br}$.

Further observations in this vein have been made during this investigation. Potassium iodide is stable in the $\mathrm{KNO}_{3}-\mathrm{NaNO}_{3}$ eutectic, a fact which is surprising since $\mathrm{Cr}^{+3}$ and $\mathrm{Mn}^{+2}$ are oxidized spontaneously by the nitrate to $\mathrm{CrO}_{4}=$ and $\mathrm{MnO}_{2}$. Gruen has commented that "nitrate melts would exhibit oxidizing properties with the nitrate ions acting as oxidizing agents in the presence of strong oxide acceptors such as U(IV), $\mathrm{NP}(\mathrm{IV})$ and $\mathrm{Pu}(\mathrm{III})$ ". $^{9}$ He further notes that these species are oxidized to $U(V I), N p(\nabla)$ and Pu(VI), presumably as oxygen containing complex ions. The iodide ion is oxidized by the nitrate melt, however, if an acid such as metaphosphate ion, cobaltous ion, or nickelous ion is present. The same holds true for the bromide ion in these melts. It can be seen that a strong oxide ion acceptor is needed to enable the nitrate ion to act as an oxidizing agent.

In the case of the IICl-KCI eutectic solvent, the diohromate ion does not react with the chloride ion but will react with $\mathrm{HCl}$ dissolved in the melt, to evolve chlorine, or with the chloride ion of the melt when metaphosphate ion is present, again yielding chlorine. Once again, the oxidation process depends upon a preceding acid-base reaction. It is now apparent that oxygen containing oxidants 
such as nitrate ion, permanganate ion and dichromate ion function as such only in the presence of a Iux-Flood acid. In the cases where the reductant concerned is capable of accepting oxide ions by itself, such as $\mathrm{Cr}^{+3}, \mathrm{Mn}^{+2}$ and $\mathrm{U}(\mathrm{IV})$, no other acid is needed. Reductants such as halide ton are not capable of accepting oxide ions and are not oxidized unless an acid is present. The interrelation of acidbase reactions and oxidation-reduction processes is thus clearly apparent.

It is interesting to note that a similar interrelation has been mentioned by Duke for the case of oxidation-reduction reactions in aqueous solution. Duke states that "an oxidationreduction reaction is preceded by or is simultaneous with, a generalized acid-base reaction". ${ }^{45}$ This investigation has extended such a concept to fused salts and has shown that all the reactions cited here can be explained in this way. 
VII. CONCLUSIONS

1. Complex ions in fused salts have been studied by means of absomption spectroscopy. The method of Continuous Variation and the method of McConnell and Davidson have been applied to the cobaltchloride system with moderate success. Limitations found for these methods are that the complex ion formed must be strong, and that the spectral shifts resulting from complexation must be large. A new spectrophotometric method for the determination of the formation constants of lead-chloro and lead-bromo complexes has been devised. Identification of chromate and dichromate ions has been made spectrophotometrically, and the acid-base behavior of these ions examined and explained.

2. Using mass spectral techniques, the products of the reaction of dichromate ion with nitrate ion have been identified as chromate ion and $\mathrm{N}_{2} \mathrm{O}_{5}$ or its decomposition products. A new method using $\mathrm{CO}_{2}$ evolution has been developed for the direct determination of acidic oxy-anions in fused salts, and a possible method of analysis for oxide ion by this technique has been suggested.

3. It has been shown that in the case of oxygen-containing oxidants, the oxidation-reduction reaction has assoclated with it an acid-base reaction of the Lux-Flood type, i.e., an exchange of an oxide ion. 
VIII. IITERATURE CITED

1. Janz, G.J., Solomons, C., and Gardner, H.J., Chem. Revs., 58, 461 (1958).

2. Bockris, J.0'M., Modern Aspects of Electrochemistry, Vol. 2, Academic Press, New York (1959).

3. Janz, G.J., "Bibliography on Molten Salts, "Rensselaer Polytech. Inst., Troy, N. Y. (1958).

4. Charnoff, L., Master's Thesis", Washington Square College, New York University (1958).

5. Sakai, K., J. Phys. Chem., 6I, 1131 (1957).

6. Sundheim, B.R. and Greenberg, J., J. Chem. Phys., 28, 439 (1958).

7. Sundheim, B.R. and Greenberg, J., J. Chem. Phys., 29, 1029 (i958).

8. Sundheim, B.R., Paper presented at Conference on Molten Salts, New York Academy of Science, April 1959.

9. Gruen, D.M., J. Inorg and Nuclear Chem., 4, 74 (1957).

10. Gruen, D.M. and MacBeth, R.I., J. Phys. Chem., 63, 393 (1959).

11. Gruen, D.M., Proc. Sec. U.N. Intern. Conf. Peaceful Uses Atomic Energy, 28, 112 (1958).

12. Gruen, D.M., Paper presented at Conference of Molten Salts, New York Academy of Science, April 1959.

13. Boston, C.R. and Smith, G.P., J. Phys. Chem., 62, 409 (1958).

14. Boston, C.R. and Smith, G.P., Paper presented at Conference on Molten Salts, New York Academy of Sciences, April 1959.

15. Duke, F.R. and Iverson, M.I., J. Am. Chem. Soć., 80, 5061 (1958).

16. Duke, F.R. and Iverson, M.I., J. Phys. Chem., 62 477 (1958).

17. Temkin, M., Acta Physicochjm. U.R.S.S., 20, 411 (1945).

18. Bockeris, J.0'M., and Richards, Proc. Roy. Soc., 247, 44 (1957).

19. Iewis, F.N.; J. Franklin Inst., 226, 293 (1958).

20. Iux, H., Z. Elektrochem., 45, 303 (1939). 
21. Audrieth, L.F. and Moeller, T., J. Chem. Ed., 20, 219 (1943).

22. Flood, H., and Forland, T., Acta Chem. Scand., 1, 592 (1947).

23. Job, Ann. chim., 9, 113 (1928).

24. Vosburg, W.C. and Cooper, G.R., J. Am. Chem. Soc., 63, 437 (1947).

25. McConnell, H. and Davidson, N.J., J. Am. Chem. Soe., 72 , 3165 (1950).

26. Burns, E. and Hume, D.J., J. Am. Chem. Soc., 79, 2704 (1957).

27. Sundheim, B.R. and Greenberg, J.,Rev. Sci. Instruments, 27, 703 (1956).

28. Gmuen, D.M., Nature, 178, 1181 (1956).

29. Power, R. and Hackerman, N., J. Phys. Chem., 56, 187 (1952).

30. Int. Crit. Tables, lst Ed., Vol. IV, p.67, McGraw-Hill Book Company, New York (1928).

31. Int. Crit. Tables, Ist Ed., Vol. IV, p.69, McGraw-Hill Book Compainy, New York (1928).

32. Laitinen, H.A., Ferguson, W.S. and Osteryoung, R.A., J. Electrochem. Soc., 104, 516 (1957).

33. Burkhard; W.J. and Corbett, J.D.; J. Am. Chem. Soc., 79, 6361 (1957).

34. American Society for Testing Materials, Publication No.48-D (1954).

35. Gruen, D.M., private communication.

36. Smith, G.P., private communication.

37. Duke, F.R. and Doan, A.S., Iowa State College J. of Sci., 32, 451 (1958).

38. Kordes, E., Bergman, W. and Vogel, W., Z. Elektrochem., 55 , 600 (1951).

39. Int. Crit. Tables, lst Ed., Vol. II, D. 27, McGraweHill Book Company, New York (1928). 
40. Van Artsdalen, E.R., J. Phys. Chem., 60, 176 (1956).

41. Ingold, C.K., Millen, D.J. and Poole, H.G., J. Chem. Soc., $1950,2276$.

42. Millen, D.J., J. Chem. Soc., $1950,2589$.

43. Ingold, C.K., Millen, D.J. and Poole, D.J., Nature, 158, 480 (1946).

44. Duke, F.R. and Iverson, M.L., Anal. Chem., 31, 1233 (1959).

45. Duke, F.R., Anal. Chem., 31, 527 (1959). 


\section{Part II \\ Polarographic Determination of Formation Constants of Complex Ions in Fused $\mathrm{LiNO}_{3}-\mathrm{KnO}_{3}$}


Introduction

The feasibility of using the dropping mercury electrode (d.m.e.) in fused nitrate melts was demonstrated several years ago by steinberg and Nachtrieb..$^{1}$ Their work indicated that in sufficiently low melting systems the d.m.e. could be utilized in much the same way that is is used in aqueous solutions. One use of the polarographic technique in aqueous solutions has been to study complex ions; in certain instances, formation constants for complex ionic species may be determined."

The existence of complex ions in fused salts has been demonstrated, most recently by Gruen ${ }^{3}$ and Van Norman, and data on the formation constants for various species have been obtained. $5,6,7,8$

It appears that the metal-halide oomplex ions formed in fused salts are characterized by rather weak formation constants. An aqueous polarographic technique for the study of such complexes was derived by DeFord and Hume. 9 The present work is an attempt to apply this method to the determination of formation constants of metal-halide complexes in a $\mathrm{LiNO}_{3}-\mathrm{KNO}_{3}$ fused salt system.

\section{Experimental}

Reagent grade chemicals were used in all cases. The $\mathrm{LiNO}_{3}$ $\mathrm{KNO}_{3}$ eutectic system $\left(38.56 \text { mole } \% \mathrm{LiNO}_{3}, \mathrm{~m} \cdot \mathrm{p} \cdot 139^{\circ} \mathrm{C}\right)^{10}$ was prepared from vacuum-oven dried material. In oll cases the eutectic material was mixed, fuocd and filtered through a fine sintered glass frit. Metal ions were added to this mixture as the metal nitrates driof under vacuum at $100^{\circ} \mathrm{C}$. Additions of chloride were made by adding weighed amounts of vacuum dried potassium chloride to the melts. 
The molt was containod in a $100 \mathrm{ml}$. beaker and was placed in a tubular furnace consisting of a Vycor core (58 mn dianeter) wound with Hichrome $\mathrm{V}$ wire and covered with insulating cement. A mercury thermonetcr was dipped into the nelt to neasure the terperature whtch was naintained a.t $180^{\circ} \mathrm{C}$ by means of a Variac.

The reference eloctrode corpartment consisted of a small pyrex tube, sealed at one end with a fine fritted glass disc. The twbe was placed in the relt and wa!s filled with $\mathrm{LiNO}_{3}-\mathrm{KNO}_{3}$ outocttc containing $3.86 \mathrm{ng}$. of $\mathrm{KCl}$ per gram of cutectric. The nelt in the fritted corrparticent was saturated with silver chloride and a silvor wire was imersed in the reforence corpartuent, giving al silver-silver chloride cloctrode.

The capillary for the d.a.e. was a $3-5$ second polarographic capillary, 2lch. long (E.H.Sargont and Co., Chicago Ill.). This was sufficiently long that while one end dipped into the nelt, the other end was well out of the furnace. Contact to a nercury reservoir was made with Tygon tubing attached to the capillary. A drop tine of about 4.5 seconds resulted at a head of $68 \mathrm{~cm}$. of nercury at -0.35 versus the Ag-AgCI refor ence electrode. All polarogrars were recorded in the conventional manncr with a Sargent Model XXI Recording Polarograph.

Potentials were chocked by stopping the polarograph at given intervals and noasuring the applied e.n.f. with a Rubican Pntent-r. tioneter (Cat. No. 2700). 
In making a man, a weighed amount of $\mathrm{LiNO}_{3}-\mathrm{KNO}_{3}$ eutectic was placed in the $100 \mathrm{ml}$ beaker, together with the filled reference electrode, and brought up to temperature in the furnace. A residual current was run and a weighed amount of metal nitrate was added. Polarograma were thon taken as weighed amounts of potassium chloride were added.

In the case of nickel, it was found that when nickel nitrate was mixed with the eutectic, a black precipitate, presumably nicke] oxide, formed. To forestall this, nickel nitrate. was mixed with the eutectic, fused and filtered through a sintered glass frit, removing the precipitated material. Thus, the concentration of the nickel was not known but it is estimated from the wave height that the concentration of nickel was of the order of millimolal(noles/ $1000 \mathrm{g.})$. A knowledge of the exact concentration of nickel in the nolt is not necessary in the following troatment, however.

\section{Results and Discussion:}

The residual currents obtained were linear over the useful range from about 0.0 . Volts (mercury dissolution) to 0.8 volts versus the $\mathrm{Ag}-\mathrm{AgCl}$ referencc electrode (reduction of alkali netal or nitrate iet). The maximun current obtained in this range was about 0.3 microamperes(at -0.8 volts). Normal polarograns with no maxima were obtailida fur the reduction of $\mathrm{Ni}(11)$, and $\mathrm{Ca}(11)$. 
The slopes of the plots of $E$ versus $\log \left[\left(i_{d}-i\right) / i\right]$ were $0.47,0.52$ and 0.52 for the reduction of $\mathrm{Ni}(\mathrm{II}), \mathrm{Cd}(\mathrm{II})$ and $\mathrm{Pb}(\mathrm{II})(2.303 \mathrm{RT} / \mathrm{F}=0.090$ at $180^{\circ} \mathrm{C}$ ) respectively. These reductions thus appear reversible. Shifts of the halfwave potentials to more negative values were noted as increasing amounts of chloride were added. The polarograms in Fig. I show the shifts in the wave relative to the uncomplexed material as KCl was added to the melt containing lead nitrate.

Table I indicates $i_{d}$ for the reduction of $\mathrm{Cd}(\mathrm{II})$ corrected for residual current and the slight dilution of the melt by added KCl as a function of added $\mathrm{KCl}$.

Table I

Cadmium Nitrate

\begin{tabular}{|c|c|c|c|c|c|c|c|c|}
\hline & I. & & & II & & & III & \\
\hline $\begin{array}{l}\text { moles/ } \\
1000 \mathrm{~g} .\end{array}$ & $\Delta E_{\frac{1}{2}}(\mathrm{mv})$ & $i_{d}(\mu a)$ & {$[\mathrm{KCl}]$} & $\triangle E^{\frac{1}{2}}(\mathrm{mv})$ & $i_{d}(\mu a)$ & {$[\mathrm{KCI}]$} & $\Delta E_{\frac{1}{2}}(\mathrm{mv})$ & $\dot{i}_{d}(\mu a)$ \\
\hline$\cdots$ & $\cdots$ & 9.76 & $\cdots$ & •..." & 10.84 & $\cdots$ & $\cdots$ & 18.1 \\
\hline 0.0208 & 39.6 & 9.70 & 0.0091 & 18.2 & 10.87 & 0.0116 & 24.8 & $17 \cdot 2$ \\
\hline 0.0386 & 55.7 & 9.46 & 0.0195 & 36.2 & 10.89 & 0.0264 & 42.9 & 17.4 \\
\hline 0.104 & 103.3 & 9.26 & 0.0325 & 55.6 & 11.18 & 0.042 & 59.3 & 18.8 \\
\hline 0.170 & 136.6 & 9.54 & 0.0465 & 72.0 & 11.39 & 0.0604 & 78.2 & 19.0 \\
\hline 0.230 & 151.2 & 9.54 & 0.0698 & 94.6 & 11.41 & 0.0801 & 84.4 & 18.5 \\
\hline 0.342 & 180.0 & 9.65 & 0.0101 & 112.2 & 11.14 & 0.102 & 106.4 & 18.5 \\
\hline \multirow[t]{5}{*}{0.458} & 201.6 & 9.50 & 0.134 & 124.2 & 11.60 & 0.161 & 124.8 & 18.0 \\
\hline & & & 0.218 & 157.2 & 10.68 & $0.24 n$ & 755.7 & 17.7 \\
\hline & & & 0.345 & 184.2 & 10.48 & 0.336 & 186.6 & 17.6 \\
\hline & & & 0.529 & 219.7 & 9.63 & 0.446 & 200.2 & 17.2 \\
\hline & & & & & & 0.590 & 217.2 & 17.0 \\
\hline
\end{tabular}

Table II indicates $1_{d}$ for the reduotion of $\mathrm{Pb}(\mathrm{II})$ corrected for residual current and the slight dilution of the melt by added KCI as a function of added $\mathrm{KCl}$. 
is

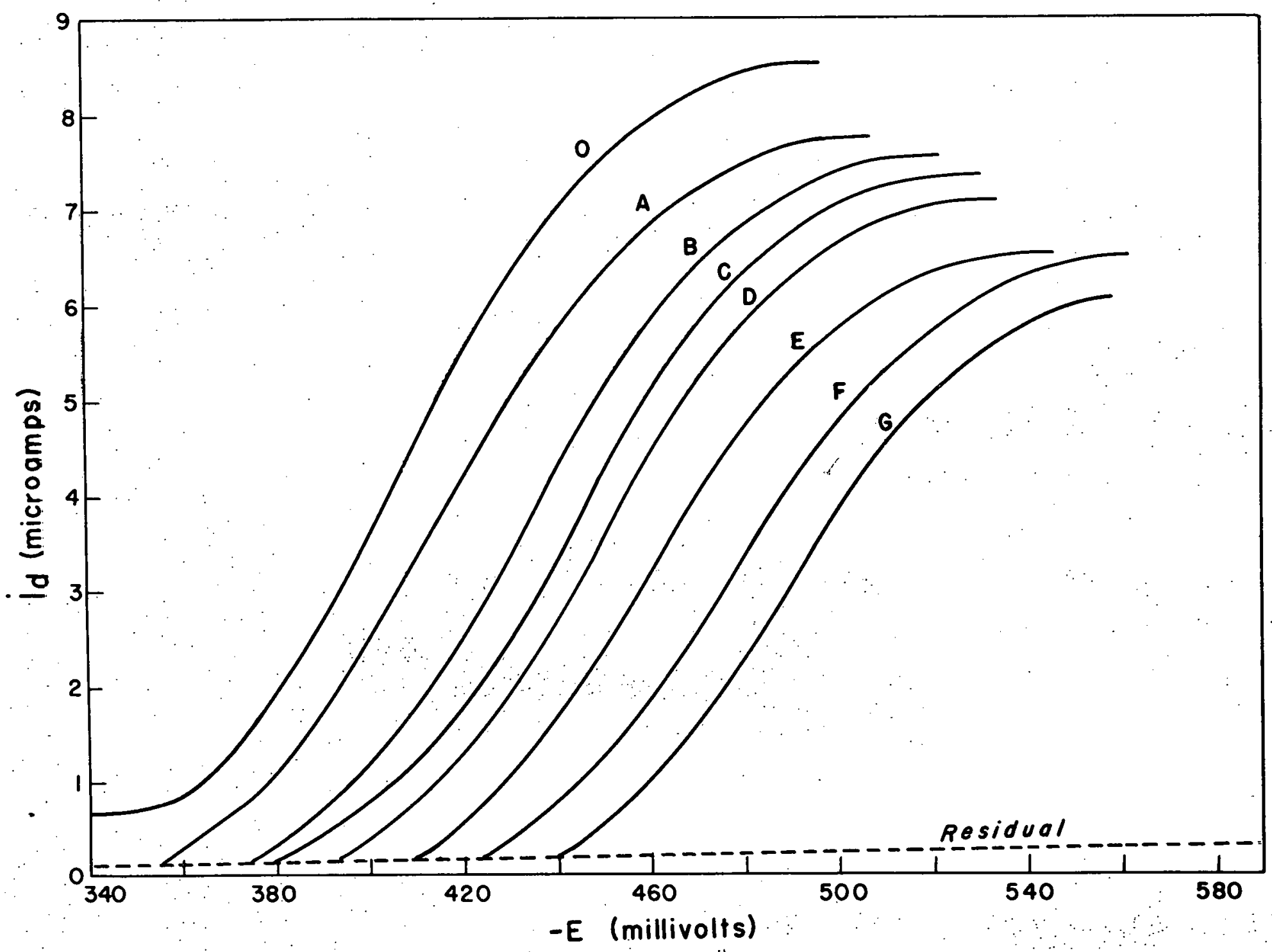

Figure 1 


\begin{tabular}{|c|c|c|c|c|c|}
\hline ECII & $\triangle E_{2}^{2}(\operatorname{mv})$ & $i_{d}(\mu a)$ & [KC] & $\Delta \mathrm{m}^{\frac{1}{2}}(\mathrm{nv})$ & $i_{d}\left(u_{3}\right)$ \\
\hline - & - & 8.64 & - & - & 18.88 \\
\hline 0.0248 & 10.9 & 8.08 & 0.119 & 29.4 & 17.26 \\
\hline 0.0607 & 25.5 & 7.79 & 0.238 & 55.5 & 16.15 \\
\hline 0.0975 & 34.0 & 7.64 & 0.351 & 65.6 & 15.00 \\
\hline 0.149 & 41.9 & 7.55 & 0.457 & 72.8 & 14.99 \\
\hline 0.225 & 46.5 & 6.91 & - & - & - \\
\hline 0.303 & 63.3 & 7.01 & 0.576 & 78.1 & 15.24 \\
\hline 0.372 & 65.3 & 7.05 & - & - & - \\
\hline 0.481 & 7.01 & 7.05 & 0.832 & 91.3 & 14.26 \\
\hline 0.743 & 8.45 & 6.84 & - & - & - \\
\hline
\end{tabular}

Table III indicates $i_{d}$ for the reduction of $\mathrm{Ni}(11)$, corrected for the residual current and the slight dilution of the melt by added KCl is $\therefore$ function of added $\mathrm{KCl}$.

Table III

Nickol Nitrate

\begin{tabular}{|c|c|c|c|c|c|}
\hline [KCI] & $\triangle E^{1}$ & $i_{d}(j a)$ & [ $\mathrm{KC}]$ & $\triangle^{111} \mathrm{E}_{2}^{1}(\mathrm{mv})$ & $i_{d}\left(\mu \varepsilon_{i}\right)$ \\
\hline - & - & 20.4 & - & - & 1.36 \\
\hline 0.0098 & 9.1 & 20.6 & 0.0101 & 3.4 & 1.30 \\
\hline 0.0296 & 12.8 & 20.5 & 0.0298 & 11.8 & 1.15 \\
\hline 0.0615 & 16.3 & 19.9 & 0.0612 & 17.8 & 1.04 \\
\hline 0.123 & 29.7 & 19.5 & 0.118 & 31.4 & $0.9 ! 4$ \\
\hline 0.244 & 48.9 & 19.4 & .0 .208 & 46.8 & 0.92 \\
\hline 0.416 & 70.0 & 18.7 & 0.305 & 58.2 & $0 . \dot{96}$ \\
\hline U.582 & 80.3 & 18.5 & 0.415 & 71.7 & 0.93 \\
\hline- & - & - & 0.502 & 80.0 & 0.90 \\
\hline - & - & - & 0.606 & 88.8 & 0.88 \\
\hline - & - & - & 0.707 & 94.0 & 0.86 \\
\hline
\end{tabular}


It is to be noted that the diffusion current decreases somewhat as the concentration of added chloride increases. This effect is most striking in the case of lead: in the case of nickel and cadmium, the effect is not so great, but the diffusion current does decrease at higher concentrations of added chloride. The slight increase in the diffusion current at lower concentrations of chloride may be due to the dissolution of a small amount of metal oxide in equilibrium with the metal ion in solution. This redissolution would tend to effect the slight decrease in the diffusion current due to the formation of complex ions. The decrease in the diffusion current is taken as an indication of the formation of a complex ion or a series of complex ions: it might be expected that as the size of the average species diffusing to, the electrode increases, the diffusion coefficients would decrease, resulting in a decrease in the diffusion limited current. To ascertain that the currents were indeed diffusion controlled, $i_{d}$ was determined at various heights of the mercury column and $\log i_{d}$ versus $\log h$ (height of mercury column) was plotted. A slope of 0.498 for the least squares line indicated a diffusion controlled current. 11 .

The $\triangle E \frac{1}{2}$ for each of the reductions are shown in Tables $I, I I$ and III. The $E_{\overline{2}}^{\frac{I}{2}}$ varied from one run to the next, probably due to variations in the reference electrode. This variation is not serious, however, as $\triangle E \frac{1}{2}$ is used in the treatment of data.

An attempt was made to treat the data by the method of DeFord and Hume. It was necessary to assume that the activity coefficients of the metal ions wore unity and that the reductions were polarographically reversible. For details, reference is made to the original paper by DeFord and Hume.

$$
\text { 6ु) }
$$


The plots of the F-functions for the chloro-complexes of cadmium are shown in Figs. 2,3 and 4, where:

$$
\begin{aligned}
& \left.F_{0}=\operatorname{antilog} \frac{I}{2.303} \frac{n F}{R T}\left[\left(E_{1 / 2}\right)_{S}-\left(E_{1 / 2}\right)_{c}\right]+\log \frac{(i d)}{I_{d}}\right)_{c}=\sum_{i=0}^{i} \beta_{1} c_{x}^{\prime} \\
& F_{1}=\frac{F_{0}-\beta_{0}}{c_{x}}=\sum_{i=1}^{i} \beta_{i} c_{x}^{i-1} \\
& F_{2}=\frac{F_{1}-\beta_{1}}{c_{x}}=\sum_{i=2}^{i} \beta_{i} c_{x}^{i-2} \\
& F_{3}=\frac{F_{2}-\beta_{2}}{c_{x}}=\sum_{i=3}^{i} \beta_{i} c_{x}
\end{aligned}
$$

$R, T, n$, and $F$ have their usual significance; $\left(E \frac{1}{2}\right)_{c}$ is the halfwave potential of the metal ion in the presence of the complexing species $\mathrm{X}$; $\left(E \frac{1}{2}\right)_{S}$ is the halfwave potential of the metal ion in the absence of the complexing agent $X ;\left(i_{d}\right)_{s} /\left(\dot{i}_{d}\right)_{c}$ is the ratio of the diffusion currents in the absence and presence of $x_{;} \beta_{i}$ is the formation constant for the ith species and $c_{x}^{i}$ is the concentration of the complexing agent $X$ raised to the ith power. Thus,

$$
\begin{aligned}
& \beta_{0}=1 \\
& \beta_{1}=K_{1}=\frac{\left[M X^{n-1}\right]}{\left[M^{+n}\right][X]} \\
& \beta_{2}=K_{1} K_{2}=\frac{\left[M X_{2}^{n-2}\right]}{\left[M^{+n}\right][X]^{2}} \\
& \beta_{3}=K_{1} K_{2} K_{3}=\frac{\left[M X_{3} n-39\right]}{[M+n]\left[X_{3}\right]^{3}}
\end{aligned}
$$


where the $K^{\prime}$ s are the successive formation constants for the complex series $\mathrm{MX}^{\mathrm{n}-1}, \mathrm{MX}_{2}{ }^{\mathrm{n}-2}$, etc. A plot of $\mathrm{F}_{0}$ versus the concentration of the complexing species yields a curve with intercept 1 and limiting slope of $\beta_{1}$. A plot of $F_{1}$ versus concentration of complexing agent has an intercept of $\beta_{2}$ and a limiting slope of $\beta_{2}$. The plot of the F-function for the next to last complex $\left(F_{n-1}\right)$ will be a straight line of slope $\beta_{i}$ and the plot of the F-function for the last complex will be a straight line parallel to the abscissa. It is to be noted that in Figs. 2,3 and 4 the $K^{\prime}$ s quoted are total formation constants and not successive formation constants. Figures 5 and 6 give the $F$ plots for load-chloro complexes while Figs. 7 and 8 give them for nickel-chloro complexes, the $\mathrm{K}^{\prime}$ 's being again the total formation constants.

Table IV gives the experimentally obtained values for the successive formation constants for the $\mathrm{Pb}(\mathrm{II}), \mathrm{Ni}$ (II) and $\mathrm{Cd}(\mathrm{II})$ chloro complexes. Each value shown is the average of two or three separate determinations. Estimated errors are $30 \%$ for $K_{1}$, and $K_{2}$ and $60 \%$ for $\mathrm{K}_{3}$ and $\mathrm{K}_{4}$

\section{Table IY}

Successive Formation Constants of Chloro Complexes in $\mathrm{LiNO}_{3}-\mathrm{KNO}_{3}$ Eutectic at $180^{\circ} \mathrm{C}$

\begin{tabular}{cccccc}
\hline Metal Ion & $\mathrm{K}_{2}$ & $\mathrm{~K}_{2}$ & $\mathrm{~K}_{3}$ & $\mathrm{~K}_{4}$ \\
\hline $\mathrm{Ni}(\mathrm{II})$ & 26 & 2 & 10 & - \\
$\mathrm{Cd}(\mathrm{II})$ & 200 & 15 & 40 & 5 & - \\
$\mathrm{Pb}(\mathrm{II})$ & 42 & 3 & - & - \\
\hline
\end{tabular}

The data for the $\mathrm{Pb}(\mathrm{II})$ and the $\mathrm{Cd}(\mathrm{II})$ complexes may be compared roughly with the data obtained by Duke and Iverson ${ }^{\top}$ shown in Table $\nabla$. 


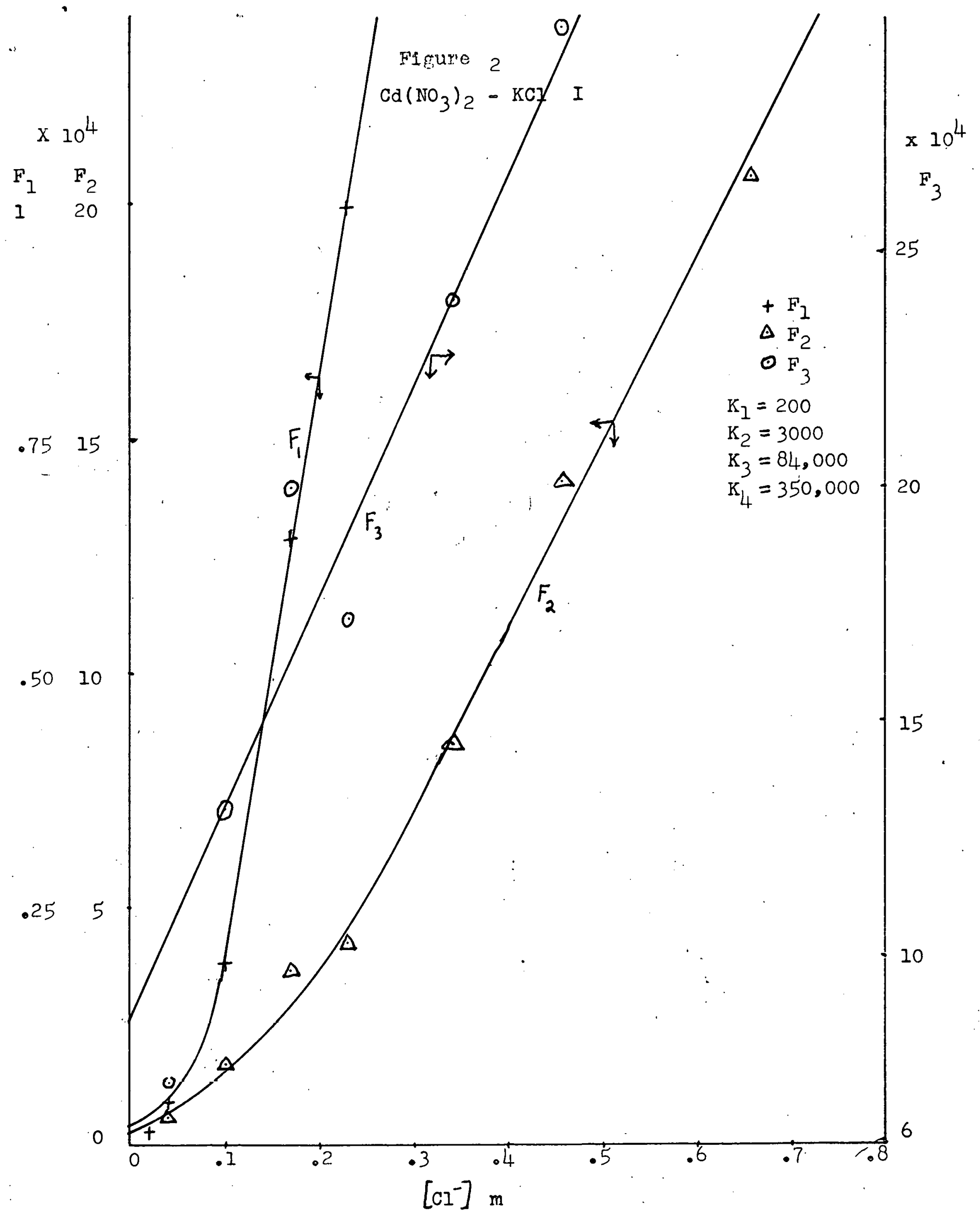




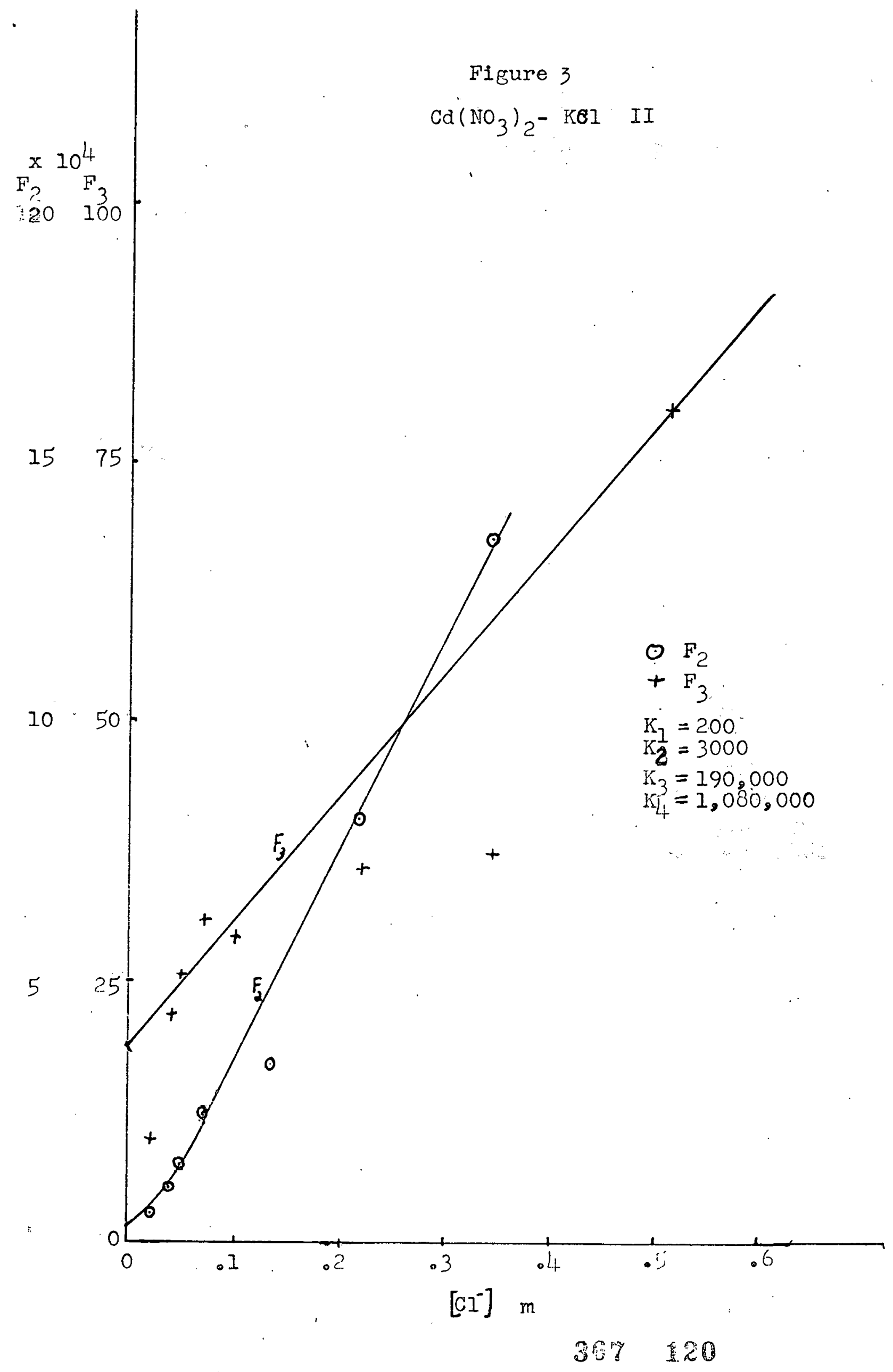


5

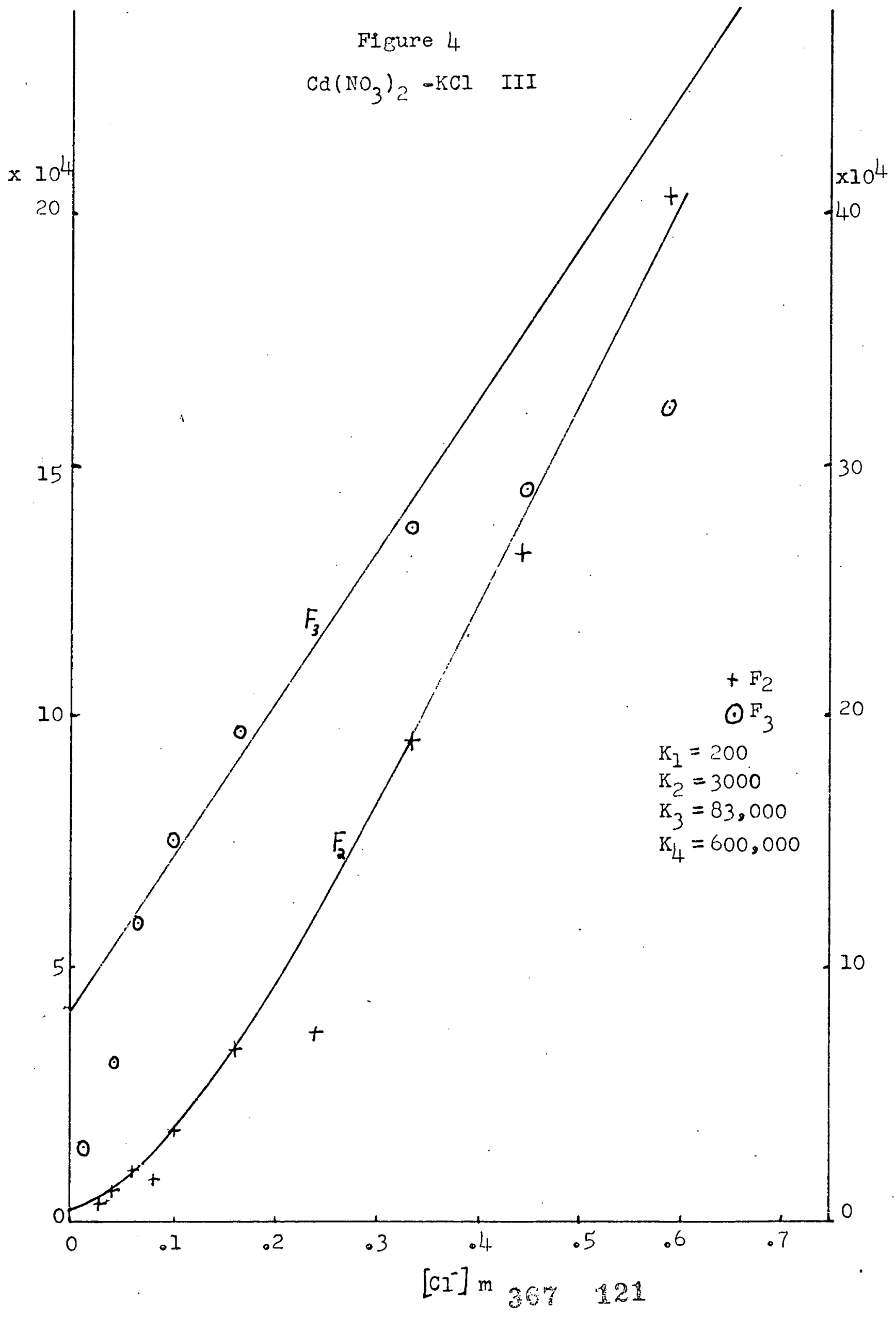




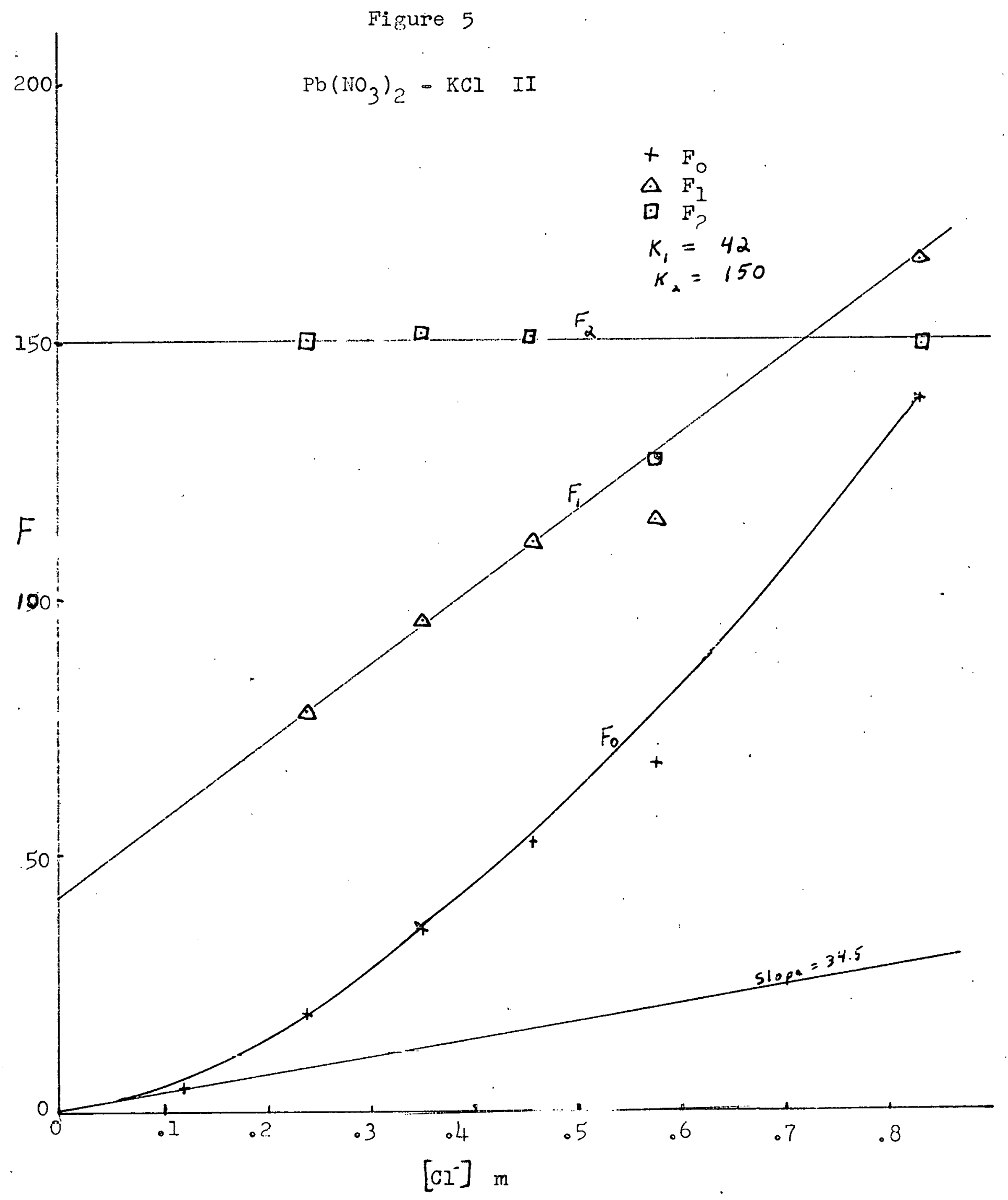

$36 \% \quad 122$ 
Flgure 6

$\mathrm{Pb}\left(\mathrm{NO}_{3}\right)_{2}-\mathrm{KCl}$ III

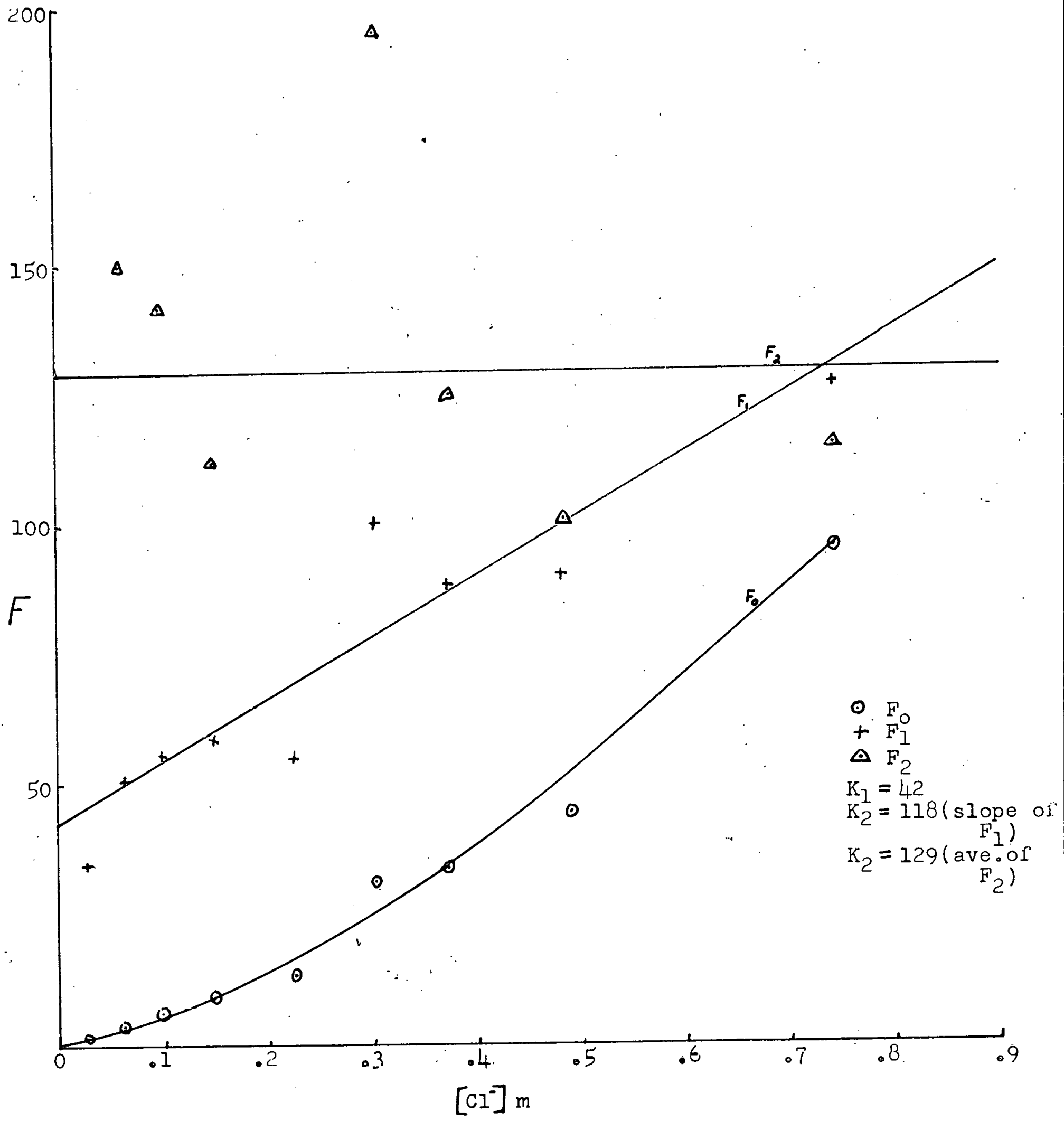




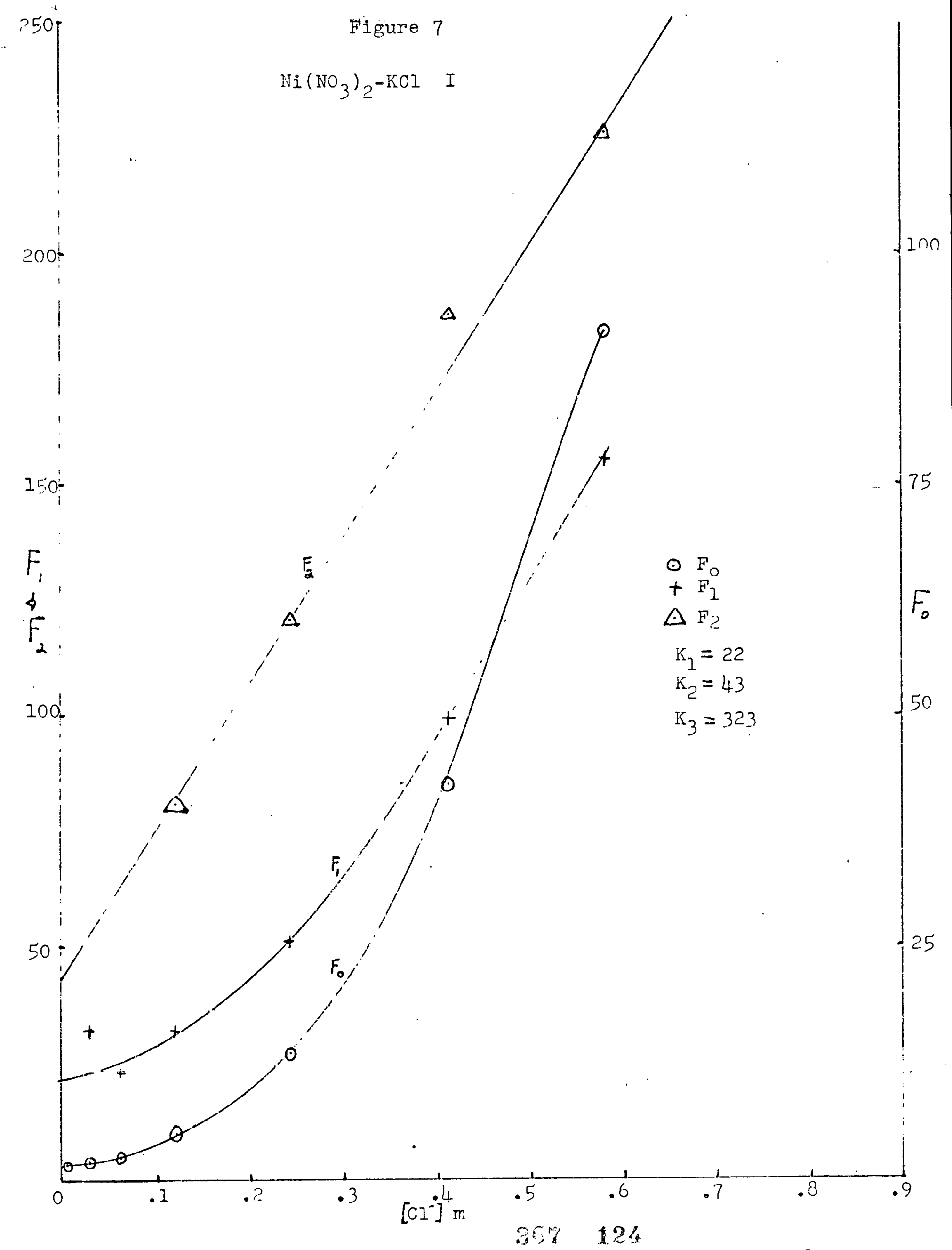




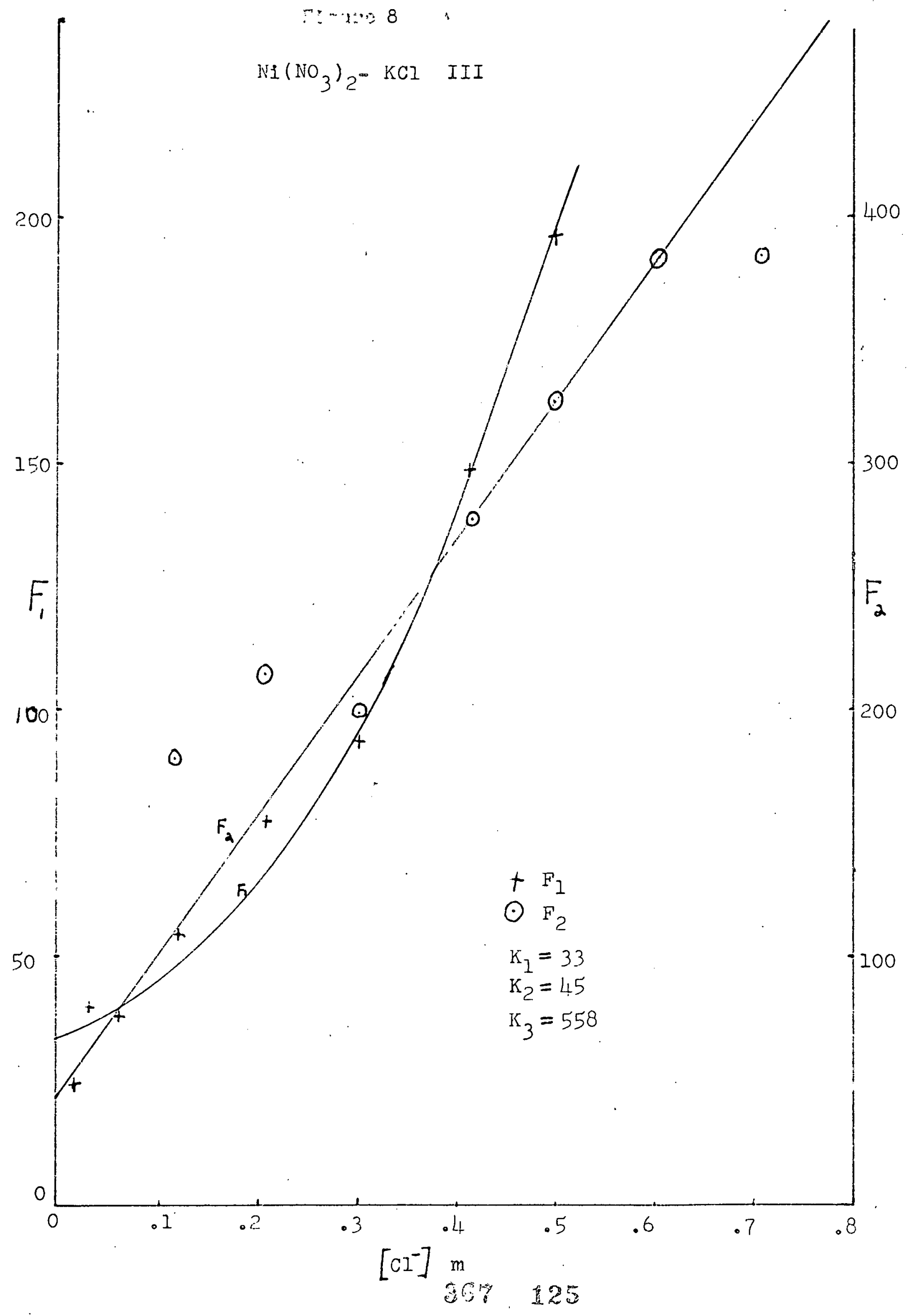


Table $\nabla$

Formation Constants if Chloro Corpilexes

17.

in $\mathrm{NaNH}_{3}-\mathrm{KNO}_{3}$

\begin{tabular}{lrrr}
\hline Constant & & Temperature ${ }^{\circ} \mathrm{C}$ & \\
\hline $\mathrm{Pb}(\mathrm{II})$ & $250^{\circ}$ & $275^{\circ}$ & $300^{\circ}$ \\
$\mathrm{K}_{1}$ & 18 & 8 & 6 \\
$\mathrm{~K}_{2}$ & 2 & 3 & 3 \\
$\mathrm{~K}_{3}$ & 2 & 1 & 1 \\
$\mathrm{Cd}(\mathrm{II})$ & & & \\
$\mathrm{K}_{1}$ & 20 & - & 24 \\
$\mathrm{k}_{2}$ & 5 & - & 5
\end{tabular}

hlthough in a different nelt and at different temperatures, the order of magnitude of the constants is such as to indicate relative agrement, particuarly when the lower terperature is taken. Van Artsdalen ${ }^{5}$, from cryoscopic neasurements in sodiun nitrate, reports that the monochloro and trichloro complexes of lead and cadnium are "not thermodynamically important". The data reported horein indicates that four complexes are important in the case of cadriun and only two, the nonochloro and dichloro, in the case of lead.

An effort was made to obtain data on the brono-complexes of lead and cadniur. In the presence of bropide in the melt, the polarographic waves for lead and cadniur exhibit naxina, precluding and accurate deternination of the shifts in halfwave potentials with the addition of bromide (EBr) to the melt. It appears however that the nonobrono-complex is about twice as stable as the corresponding monochlora-complex, and that the dibromo-

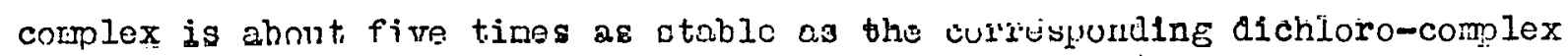
in the case of cadriun and about the sane order of stability as the dichlorocomplex as in the case of lead. Van Artsdalen 5 reports that the lamoclation constant for $\mathrm{CdCl}_{2}$ is about ten $t$ ines as great as that for $\mathrm{CdBr}_{2}$ * 
Literature Cited:

2. Steinberg,M.A., and Nachtreib, NH., J.Am.Chem.Soc..,72. 3558 (1950)

2. Kolthoff,I.M. and Lingane,J.J., Polarography, Vol.I, Interscience Publishers, New York,N.T., 1952,pp.221-215.

3. Gruen,D.M. and McBeth,R.I. J.Phys.Chem.,63, 393 (1959)

4. VanNorman,J.D. and Osteryoung,R.A., see Part I.

5. Vandrtsdalen,E.R., J .Phys.Chem.,60, 172 (1956).

6. Flengas,S.N. and Rideal,EI, Proc.Roy.Soc.(London) A233, 433 (1956)

7. Duke,F.R., and Iverson,M.I., J.Phys.Chem., 62, 417 (1959) and Anal Chem.31, 1233 (1959).

8. Neil,D., "Ph.D.Thcsig"; Rensselaer Polytech.Inst., (1959).

9. DeFord,D.D. and Kume,D.N.,J.Am.Chem.Soc.,73, 5321 (1951).

10. Internanional Criticel Tables. Ist ed. Vol. 1V, MoGraw-Hill Book Company, New York, N.Y., 1928, p.67.

12. Boference 2, pp. 85-86. 
